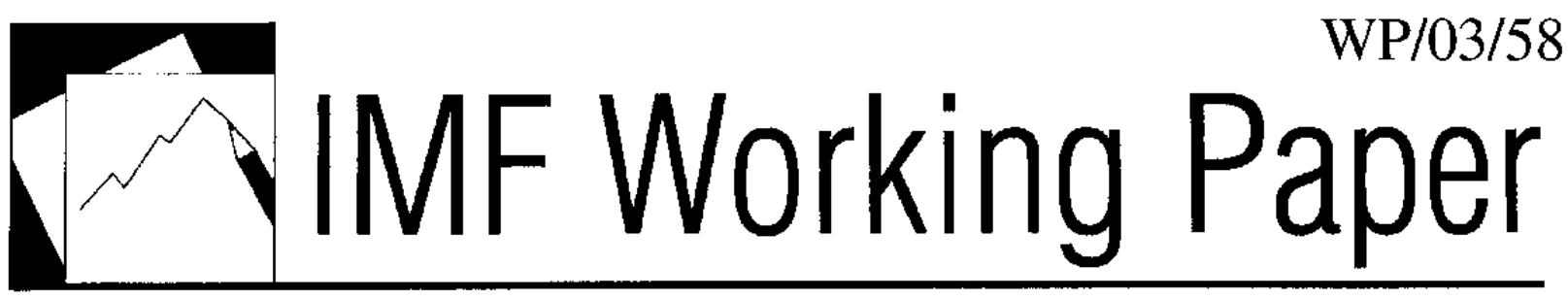

\title{
Availability of Financial Soundness Indicators
}

Graham Slack 


\title{
IMF Working Paper
}

\author{
Statistics Department
}

\section{Availability of Financial Soundness Indicators}

Prepared by Graham Slack ${ }^{1}$

Authorized for distribution by Armida San José

March 2003

\begin{abstract}
The views expressed in this Working Paper are those of the author(s) and do not necessarily represent those of the IMF or IMF policy. Working Papers describe research in progress by the author(s) and are published to elicit comments and to further debate.
\end{abstract}

Because the wave of financial crises in recent years has spurred analysts' and policymakers' interest in monitoring the vulnerabilities of financial systems, the need for supporting data has increased. This paper presents survey results on the collection, compilation, and dissemination of data on a range of indicators of financial soundness in 100 countries. The paper distinguishes between the collection of financial soundness indicators for policymakers and their dissemination to the general public. It also explores the eagerness of national authorities to disseminate the information they collect and to what extent it relates to financial crisis experience.

JEL Classification Numbers:E44, E58, G21

Keywords: Financial soundness indicators, data collection, dissemination, compilation guide Author's E-Mail Address: gslack@imf.org

\footnotetext{
${ }^{1}$ I am grateful to Mr. Gnanasiri Hettiarachchi for assistance in assembling the data, and to Mrs. Armida San José, Mr. Robert Heath, Ms. Claudia Dziobek, Mr. Sean Craig, and Mrs. Joan Gibson for helpful comments on an earlier version of the paper.
} 


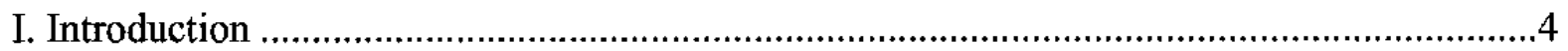

II. Banking Crises, FSIs, and Macroprudential Analysis...............................................5

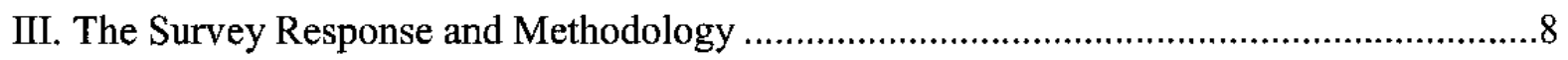

IV. Data Collection And Compilation of FSIs............................................................ 11

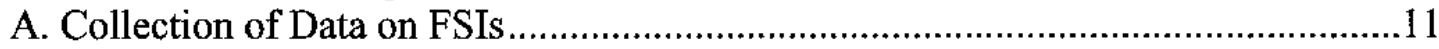

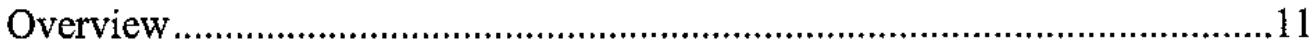

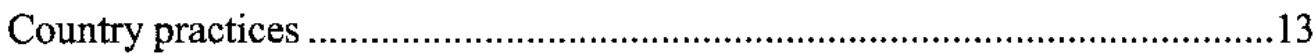

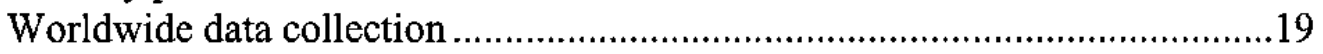

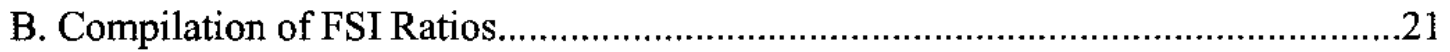

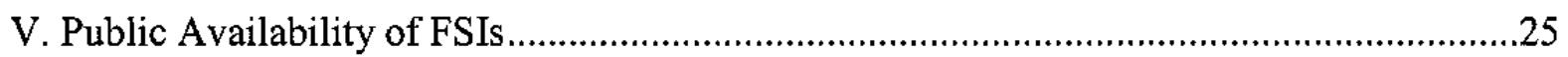

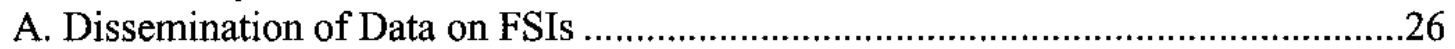

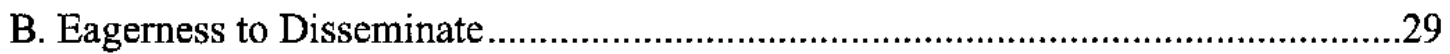

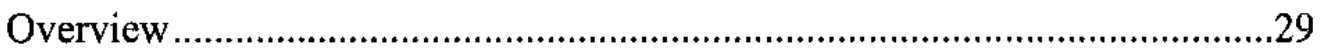

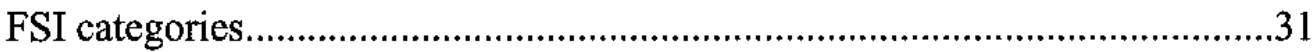

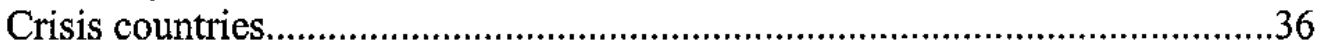

VI. Core and Encouraged Financial Soundness Indicators.............................................41

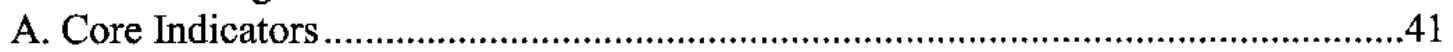

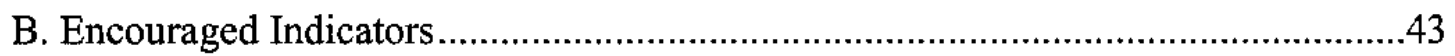

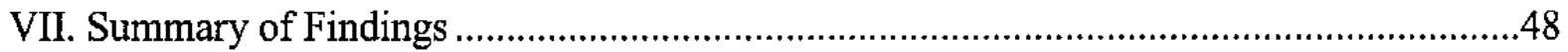

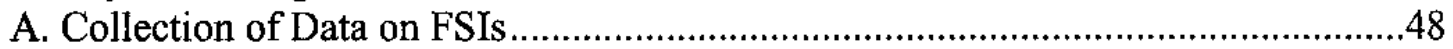

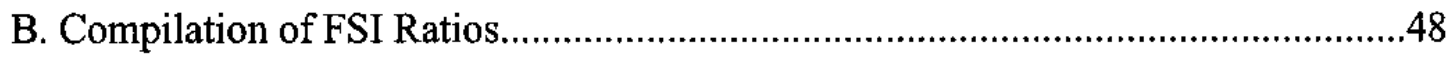

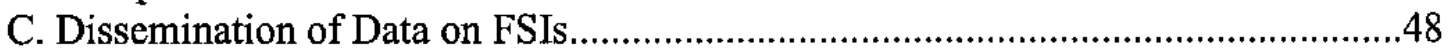

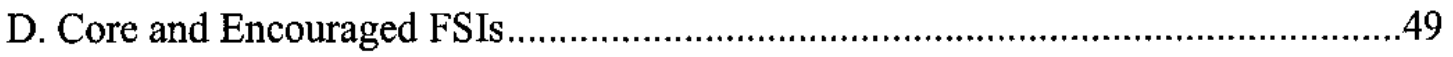

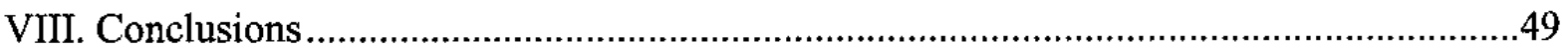

Appendixes

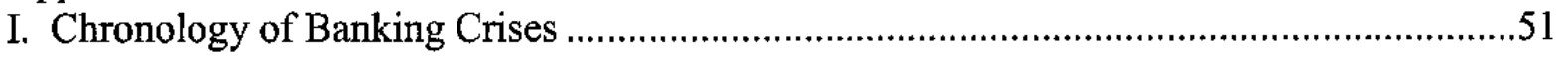

II. Table 1. Collection of Data on Financial Soundness Indicators (2000)..........................53

Table 2. Dissemination of Data on Financial Soundness Indicators (2000)....................55

Table 3. Eagerness to Disseminate Data on Financial Soundness Indicators (2000) ........57

III.Table 4. Eagerness to Disseminate Core Financial Soundness Indicators (2000) ............59

Table 5. Eagerness to Disseminate Encouraged Financial Soundness Indicators (2000)..60

References 
Tables

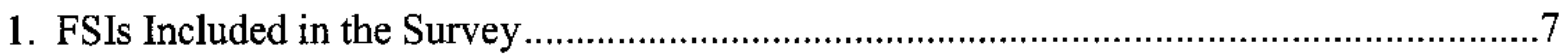

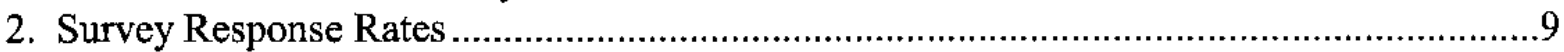

3. Core and Encouraged Financial Soundness Indicators ..............................................42

Figures

1. Percentage of Financial Soundness Indicators for Which Data Are Collected,

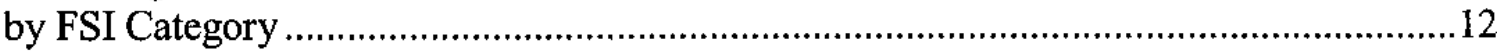

2. Percentage of Financial Soundness Indicators for Which Data Are Collected,

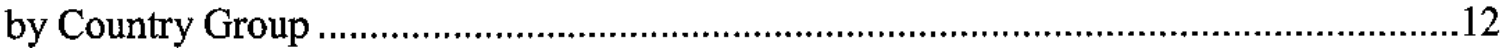

3. Percentage of Indicators on Which Data Are Collected (Mean and Standard

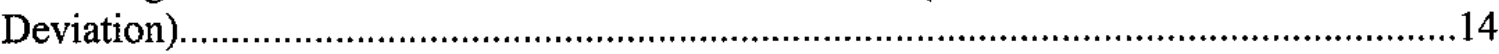

4. Percentage of Survey Respondents Collecting Data on Individual Indicators ................15

5. Percentage of Indicators on Which Data Are Collected: Crisis and Noncrisis Countries .18

6. Upper and Lower Bound Estimates of the Global Collection of Data on FSIs ................20

7. Percentage of Indicators on Which Data Are Collected and FSI Ratios Compiled...........22

8. Proportion of Collected Data Used to Compile FSI Ratios ...........................................23

9. Proportion of Collected Data Used to Compile FSI Ratios in Crisis and Noncrisis

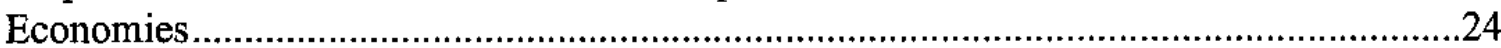

10. Comparison of Percentage of FSIs Disseminated and Percentage of FSIs Collected .......26

11. Comparison of Data Collection and Dissemination Practices, by FSI Category .............27

12. Percentage of Indicators on Which Data Are Disseminated: Crisis and Noncrisis Countries .28

13. Proportion of Indicators on Which Data Are Collected and Disseminated, by Country Group

14. Proportion of Indicators on Which Data Are Collected and Disseminated, by FSI Category .30

15. Proportion of Indicators on Which Data Are Collected and Disseminated .....................32

16. Percentage of Respondents Disseminating Data Collected on Individual Indicators.........33

17. Percentage of Collected Data on FSIs Disseminated, Disaggregated by Crisis and

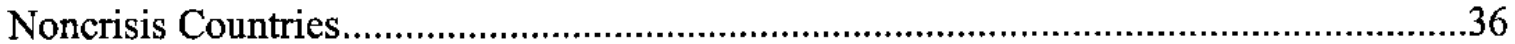

18. Proportion of Indicators on Which Data Are Collected and Disseminated: Crisis and Noncrisis Countries

19. Differences in the Eagerness of Crisis and Noncrisis Countries to Disseminate Data Collected on Individual Indicators.

20. Proportion of Countries Collecting and Disseminating Data on Core FSIs .....................44

21. Distribution of Number of Countries Collecting Data on Core FSIs .............................45

22. Proportion of Countries Collecting and Disseminating Data on Encouraged FSIs ...........46

23. Distribution of Number of Countries Collecting Data on Encouraged FSIs . 
"In view of the data deficiencies that in many cases continue to hamper vulnerability analysis, most [IMF] Directors agreed that staff reports should identify more clearly gaps in data... and discuss progress in compiling data needed for vulnerability assessments."

IMF Executive Board Public Information Notice ${ }^{2}$

November 18,2002

\section{INTRODUCTION}

Pursuant to the IMF Executive Board Public Information Notice of November 18, 2002, this paper explores the availability of country data on a range of financial soundness indicators (FSIs)-data essential for assessing strengths or vulnerabilities in financial systems. The paper provides the first detailed analysis of the collection, compilation, and dissemination of data on FSIs in 100 countries using results of the IMF's 2000 Survey on the Use, Compilation, and Dissemination of Macroprudential Indicators. ${ }^{3}$

Whereas previous papers discussed several cross-country aspects of the survey, this paper provides the first comparative analysis of practices in countries that have and have not experienced a banking crisis. ${ }^{4}$ It draws several surprising and interesting conclusions about the collection, compilation, and dissemination of FSIs in crisis and noncrisis countries.

As analysts' and policymakers' interest in monitoring vulnerabilities of financial systems has increased, the demand for supporting data has increased as well. Empirical work has shown that the costs of banking crises-both in terms of lost output and fiscal and quasi-fiscal outlays - are particularly high where banking sector problems are involved. However, work has also shown that policymakers are hampered in detecting emerging fragilities in the banking sector and implementing corrective policy actions, often owing to a lack of relevant data. $^{5}$

${ }^{2}$ International Monetary Fund, 2002, "IMF Executive Board Reviews Data Provision for Surveillance" Public Information Notice No. 02/133 (November 18).

${ }^{3}$ See http://www.imf.org/external/np/sta/fsi/eng/fsi.htm for additional information.

${ }^{4}$ Sundararajan and others (2002) provides a limited analysis of some cross-country aspects of the survey responses.

${ }^{5}$ Difficulties also exist in measuring the start and end points of banking crises because of their protracted nature and the lack of straightforward criteria to identify their onset. See, for instance, G. Corsetti, P. Pesenti, and N. Roubini, 1998; G. Kaminsky and C. Reinhart, 1999; Michael D. Bordo 1985; Gerard Caprio, Jr. and Daniela Klingebiel 1997; Barry Eichengreen and Andrew K. Rose, 1998; IMF World Economic Outlook, April 1998. Also see Ed Frydl (1999). 
Over time, analysts have used readily available data, on bank deposits for example, to identify crises associated with bank runs. However, major banking problems in recent years have pointed to difficulties that originated on the asset side of the balance sheet, with runs on banks being the result, rather than the cause, of banking problems. Therefore, analysts are increasingly recognizing as important elements of financial soundness analysis the data on indicators of credit and market risk, such as nonperforming loans, the level and fluctuation in real estate and stock prices, and business failures.

The paper is organized as follows: Section II provides some background on the incidence of banking crises over the last three decades and the role of FSIs in assessing and monitoring the strengths and vulnerabilities of financial systems. The rates of response to the survey and the methodology used in the paper are outlined in Section III. Section IV examines the collection of data on, and the compilation of, FSIs by official agencies in advanced, developing, and transition economies; and Section V examines the dissemination of official data to the public in six categories of FSIs - capital adequacy, asset quality (lending institution), asset quality (borrowing institution), profitability and competitiveness, liquidity, and sensitivity to market risks. These sections draw a distinction between the availability of FSIs in countries that have and have not experienced a banking crisis. Section VI assesses to what extent countries collect and disseminate data on the core and encouraged FSIs endorsed by the IMF's Executive Board. Section VII provides a summary of the main findings, and Section VIII concludes.

\section{Banking Crises, FSIs, And Macroprudential Analysis}

To set up context for discussing the survey results, this section provides some background on the incidence of banking crises, key aspects of banking crises, and policy responses of international and regional organizations recently.

Over the years numerous studies seeking to identify the onset of banking crises have used readily available data on banks' balance sheets, market prices, macroeconomic variables, and institutional variables. ${ }^{6}$ Bell and Pain (2000) document four such studies identifying countries that have experienced a banking crisis, or periods of banking stress, since 1971 (see Appendix I). These studies have pointed to the widespread incidence of banking crises across economies at different stages of development. Moreover, they have shown that the nature and depth of banking crises across economies can differ, depending on, among other things, the share of total assets of financial institutions accounted for by banks, the maturity of bank liabilities, the quality of local supervision and regulation, and opportunities to hedge external risk. $^{7}$

\footnotetext{
${ }^{6}$ Such studies attempt to explain the determinants (causes) of past banking crises, and/or to predict the onset, or probability, of future banking crises.

${ }^{7}$ See Rojas-Suarez and Weisbrod (1997).
} 
Macroprudential analysis, a key building block for vulnerability analysis (see Sundararajan, 2002), is at the heart of IMF and World Bank assessments of the soundness of financial systems carried out in the context of the Financial Sector Assessment Program (FSAP) and reported to the IMF's Executive Board in the Financial Sector Soundness Assessments (FSSAs). It draws on (1) quantitative information from both financial soundness indicators (FSIs) and indicators that provide a picture of economic and financial circumstances, such as GDP growth and inflation; (2) information on the structure of the financial system; (3) qualitative information on the institutional and regulatory framework; and (4) the outcome of stress tests. As an integral part of macroprudential analysis, the availability of FSIs is therefore relevant both for official and private sector assessment of the soundness of financial systems, not least because public disclosure may matter for market discipline and crisis prevention.

In response to recent financial crises, the IMF and other international and regional organizations have undertaken work to develop FSIs to monitor the current health and soundness of financial institutions and markets and their corporate and household counterparts. These FSIs include both aggregated balance sheet and income information and indicators that are representative of markets in which financial institutions operate. ${ }^{8}$ Following wide-ranging consultations during 1999 and 2000 between the IMF and other international organizations, central banks, private sector and market participants, and academics, these agencies selected a list of FSIs as representative of the work and focus of a broad range of users (see Table 1).

\footnotetext{
${ }^{8}$ See Sundararajan and others (2002).

${ }^{9}$ Further consultations were held with the Asian Development Bank, the Bank for International Settlements, the Basel Committee for Banking Supervision, the Committee on the Global Financial System, the European Central Bank, the Financial Stability Forum, the Intemational Association of Insurance Supervisors, the Organization for Economic Cooperation and Development, the World Bank, and central banks and supervisory offices in nine countries, and with representatives of the private sector - commercial and investment banks, rating agencies, investment research firms, and real estate market research firms.
} 
Table 1. FSIs Included in the Survey

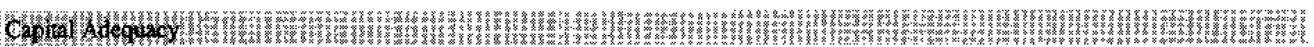
1. Capital Adequacy Ratio

2. Basel Tier 1 Capital to risk-weighted assets

3. Distribution of Capital Adequacy Ratios (Number of institutions within specified capital adequacy ratio ranges)

4. Leverage Ratio (Ratio of total on-balance sheet assets to own funds)

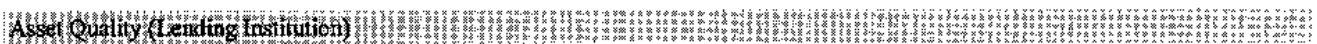
5. Distribution of on-balance sheet assets, by Basle risk-weighted category

6. Ratio of total gross asset position in financial derivatives to profits

7. Ratio of total gross liability position in financial derivatives to own funds

8. Distribution of loans, by sector

9. of which: for investment in commercial real estate

10. of which: for investment in residential real estate

11. Distribution of credit extended, by sector

12. Distribution of credit extended, by country or region

13. Ratio of credit to related entities to total credit

14. Ratio of total large loans to own funds

15. Ratio of gross nonperforming loans to total assets

16. Ratio of nonperforming loans net of provisions to tatal assets

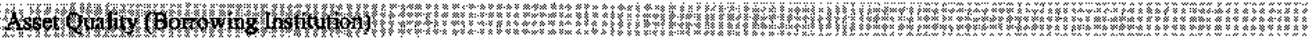

17. Ratio of corporate debt to own funds ("debt-equity ratio")

18. Ratio of corporate profits to equity

19. Ratio of corporate debt service costs to total corporate income

20. Corporate net foreign currency exposure

21. Ratio of household total debt to GDP

22. of which: mortgage debt to GDP

23. of which: debt owed to depository corporations to GDP

24. Number of applications for protection from creditors

Protability

25. Rate of change in number of depository corporations

26. Ratio of profits to period-average assets (ROA)

27. Ratio of profits to period-average equity (ROE)

28. Ratio of net interest income to profits

29. Ratio of trading and foreign exchange gains/losses to profits

30. Ratio of operating costs to net interest income

31, Ratio of staff costs to operating costs

32. Spread between reference lending and deposit rates

33. Share of assets of the three largest depository corporations in total assets of depository corporations

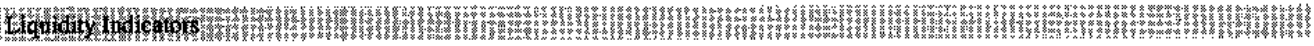
34. Distribution of 3-month local-currency interbank rates for different depository corporations

35. Average interbank bid-ask spread for 3-month local-currency deposits

36. Ratio of liquid assets to total assets

37. Ratio of liquid assets to liquid liabilities

38. Average maturity of assets

39. Average maturity of liabilities

40. Average daily turnover in the T-bill (or central bank bill) market

41. Average bid-ask spread in the T-bill (or central bank bill) market

42. Ratio of central bank credit to depository corporations to depository corporations' total liabilities

43. Ratio of customer deposits to total (noninterbank) loans

44. Ratio of customer foreign currency deposits to total (noninterbank) foreign currency loans

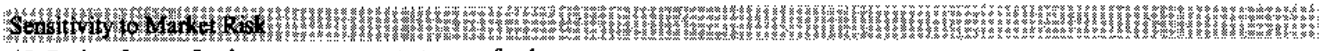

45. Ratio of gross foreign currency assets to own funds

46. Ratio of ret foreign currency position to own funds

47. Average interest rate repricing period for assets

48. Average interest rate repricing period for liabilities

49. Duration of assets

50. Duration of liabilities

51. Ratio of gross equity position to own funds

52. Ratio of net equity position to own funds

53. Ratio of gross position in commodities to own funds

54. Ratio of net position in commodities to own funds 
The IMF's Statistics and Monetary and Exchange Affairs Departments conducted a Survey on the Use, Compilation, and Dissemination of Macroprudential Indicators during the second half of 2000 to assess national practices in compiling and disseminating these FSIs. The FSIs and their components - the numerator and denominator of the FSI-were grouped into six major categories, derived from the CAMELS framework frequently used by bank supervisors to evaluate individual banking institutions. ${ }^{10}$ The six categories are capital adequacy, asset quality (lending institution), asset quality (borrowing institution), profitability and competitiveness indicators, liquidity indicators, and indicators of sensitivity to market risks (see Table 1). Sundararajan (2002) explains these FSI categories in the context of their use in macroprudential analysis.

The IMF sent the survey to central banks in more than 180 countries with a request that they coordinate its distribution, completion, and return to the IMF. The countries were asked to distribute the survey within their economies to whichever parties they judged could best provide information on practices relating to FSIs. These parties included supervisory agencies and national statistical offices.

\section{The Survey Response ANd Methodology}

More than half of the IMF membership responded to the compilation and dissemination part of the survey (see Table 2). The response was broadly based. Almost all advanced economies, 62 percent of transition countries, and almost 50 percent of developing countries responded, providing an adequate basis for analysis. The lowest rates of response were from African and Western Hemisphere developing countries (43 percent, in each case). Overall, 44 (61 percent) of the banking-crisis countries that are identified in Appendix I, and 38 (70 percent) of the 54 countries that received (or were in the process of receiving) FSSA/FSAPs as of end-2002, responded to the survey. The very strong response rate to the survey is an indication of the importance attached worldwide to issues relating to macroprudential analysis and the role of FSIs in such analysis.

\footnotetext{
${ }^{10}$ CAMELs refers to Capital adequacy, Asset quality, Management soundness, Earnings, Liquidity, and Sensitivity to market risk. The survey specified six indicators on capital adequacy. Two of these indicators are not included in the dataset used in this paper because they are specialized subcomponents of the Basel capital adequacy ratio, which is included in the dataset. The quality of management of financial institutions was not included in the survey because of concerns that quantitative measures of management would not be reliable.
} 
Table 2. Survey Response Rates

\begin{tabular}{|c|c|c|c|c|}
\hline & $\begin{array}{l}\text { Total } \\
\text { number of } \\
\text { countries } \\
\text { in the } \\
\text { WEO 1/ }\end{array}$ & $\begin{array}{l}\text { Number of } \\
\text { countries } \\
\text { responding } \\
\text { to the } \\
\text { survey } 2 /\end{array}$ & $\begin{array}{c}\text { Of which } \\
\text { received } \\
\text { FSAP/FSSA } \\
\text { (end-2002) }\end{array}$ & $\begin{array}{l}\text { Percentage of } \\
\text { countries } \\
\text { responding to } \\
\text { the survey }\end{array}$ \\
\hline All countries & 183 & 100 & 38 & 55 \\
\hline Crisis & 72 & 44 & 19 & 61 \\
\hline Noncrisis & 111 & 56 & 19 & 50 \\
\hline Advanced economies & 29 & 26 & 10 & 90 \\
\hline Crisis & 15 & 15 & 6 & 100 \\
\hline Noncrisis & 14 & 11 & 4 & 79 \\
\hline Developing countries & 128 & 58 & 19 & 45 \\
\hline Crisis & 52 & 25 & 11 & 48 \\
\hline Noncrisis & 76 & 33 & 8 & 43 \\
\hline Africa 3/ & 51 & 22 & 7 & 43 \\
\hline Crisis & 23 & 10 & 3 & 43 \\
\hline Noncrisis & 28 & 12 & 4 & 43 \\
\hline Asia & 26 & 13 & 2 & $\mathbf{5 0}$ \\
\hline Crisis & 8 & 5 & 2 & 63 \\
\hline Noncrisis & 18 & 8 & 0 & 44 \\
\hline Middle East & 16 & 8 & 3 & 50 \\
\hline Crisis & 4 & 2 & 0 & 50 \\
\hline Noncrisis & 12 & 6 & 3 & 50 \\
\hline Western Hemisphere & 35 & 15 & 7 & 43 \\
\hline Crisis & 17 & 8 & 6 & 47 \\
\hline Noncrisis & 18 & 7 & 1 & 39 \\
\hline Transition economies & 26 & 16 & 9 & 62 \\
\hline Crisis & 5 & 4 & 2 & 80 \\
\hline Noncrisis & 21 & 12 & 7 & 57 \\
\hline
\end{tabular}

1/ Including respondents that are not IMF members.

2/ Responses to compilation and dissemination part of the Survey.

3/ Responses from regional central banks are counted as one response per member country. 
Unlike previous analysis of the survey results, this paper emphasizes the cross-country aspects of the data collection, compilation, and dissemination practices of respondents and distinguishes between practices in crisis and noncrisis countries. This approach necessitated reorganizing a large volume of survey data into a format that enabled the analysis. ${ }^{11}$ The information drawn from the survey responses is shown in Appendix II (Tables 1-3) and described below:

- Country responses are grouped following the IMF's World Economic Outlook (WEO) classification-advanced economies, developing economies by region (Africa, Asia, Middle East, Western Hemisphere), and transition economies. ${ }^{12}$

- For each of the six FSI categories, the tables show the percentage of indicators on which data are collected or disseminated. For instance, Table 1 (Appendix II) shows that countries responding to the survey typically collect data on 70 percent of the indicators in the category of capital adequacy, while Table 2 (Appendix II) shows that they typically disseminate data on 40 percent of the indicators included in this category.

- For each indicator, the tables show the proportion of countries in each country group collecting or disseminating data on the indicator. For example, Table 1 (Appendix II) shows that 90 percent of countries typically collect data on the capital adequacy ratio, while Table 2 (Appendix $\Pi$ ) shows that 50 percent of them typically disseminate data on that indicator to the public.

- The tables also show the difference in the data collection and dissemination practices of crisis and noncrisis countries, based on the list of crisis countries identified in Appendix I. For example, Table 1 (Appendix II) indicates that proportionally more (30 percent more $)^{13}$ crisis than noncrisis countries collect data on the distribution of capital adequacy ratios.

\footnotetext{
${ }^{11}$ The compilation and dissemination part of the survey collected a total of 8,650 bits of information from the respondents. Each country response was reviewed, and where necessary clarifications and corrections sought from each respondent.

${ }^{12}$ Aggregation of the survey responses is necessary to maintain confidentiality of individual country responses.

${ }^{13}$ This is calculated by taking the proportion of crisis countries collecting data on the indicator ( 50 percent) and subtracting the proportion of noncrisis countries collecting data on the indicator ( 20 percent).
} 


\section{Data Collection And Compilation OF FSIS}

This section examines which data series official agencies collect that are needed for compiling FSIs and to what extent they use the data series to compile FSI ratios specified in the survey. The collection of data series on FSIs might be indicative of a country's statistical capacity. In addition, whether the countries use them to compile FSI ratios may indicate how, and perhaps whether, they use them in financial soundness analysis.

\section{Overview}

\section{A. Collection of Data on FSIs}

National agencies such as the central bank, bank supervisory agency, and statistical office, usually collect data used in policy formulation. In the case of FSIs, these agencies typically collect data on half of the 54 indicators specified in the survey (see Figure 1). ${ }^{14}$

There are important lacunas however in the collection of data on some FSIs. In particular, agencies do not widely collect data on indicators drawn from outside the traditional supervisory data sources and macroeconomic statistical frameworks. ${ }^{15}$ As a result, only one third or fewer indicators on market risk and asset quality (borrowing institution) are typically available, although financial vulnerabilities in these areas have been shown to be important elements in recent financial crises. Agencies collect data on about one-half of the indicators of asset quality (lending institution) and liquidity and on three-quarters of the indicators of capital adequacy and profitability and competitiveness.

The distribution of the highest and lowest observations around the mean in Figure 1 reveals that some countries, compared to the typical survey respondent, collect data on a significantly larger (smaller) number of FSIs. For example, whereas countries typically collect data on 29 percent of indicators of asset quality (borrowing institution), one country collects data on more than half of the indicators, and another collects data on only 15 percent of the indicators.

\footnotetext{
${ }^{14}$ Official agencies may be the primary data collectors or they may collect data from trade organizations, such as bankers associations, and commercial databases such as Bankscope. The results on data collection presented here indicate the scope of data collected by official agencies and it is possible that data series not collected by these agencies are available from other sources, particularly for some of the market-based indicators and for indicators that do not involve data on individual institutions.

${ }^{15}$ For example the 1993 System of National Accounts and the monetary statistics framework set out in the Monetary and Financial Statistics Manual (2000).
} 
Figure 1. Percentage of Financial Soundness Indicators

for Which Data Are Collected, by FSI Category (High, Mean, Low)

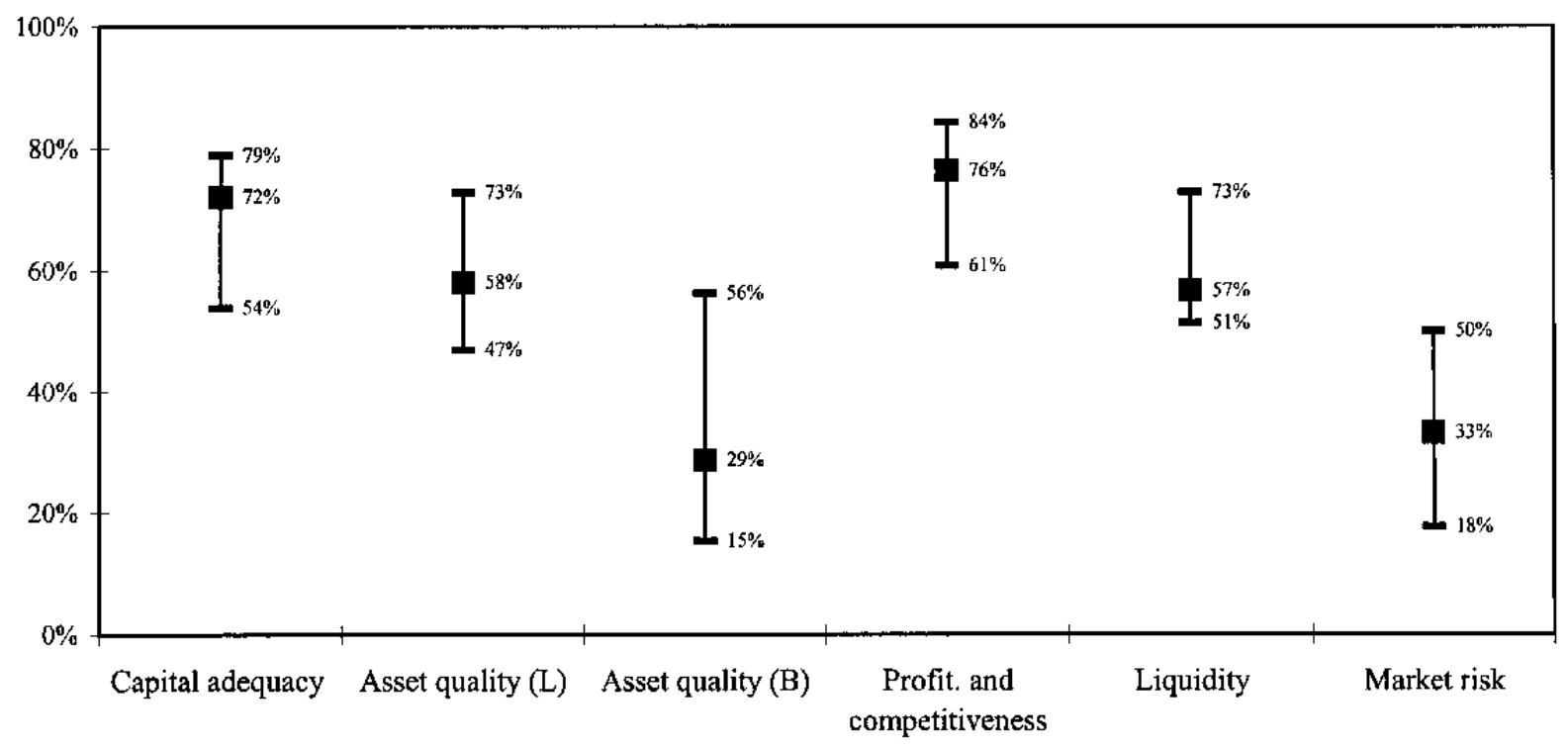

Figure 2: Percentage of Financial Soundness Indicators for Which Data Are Collected, by Country Group

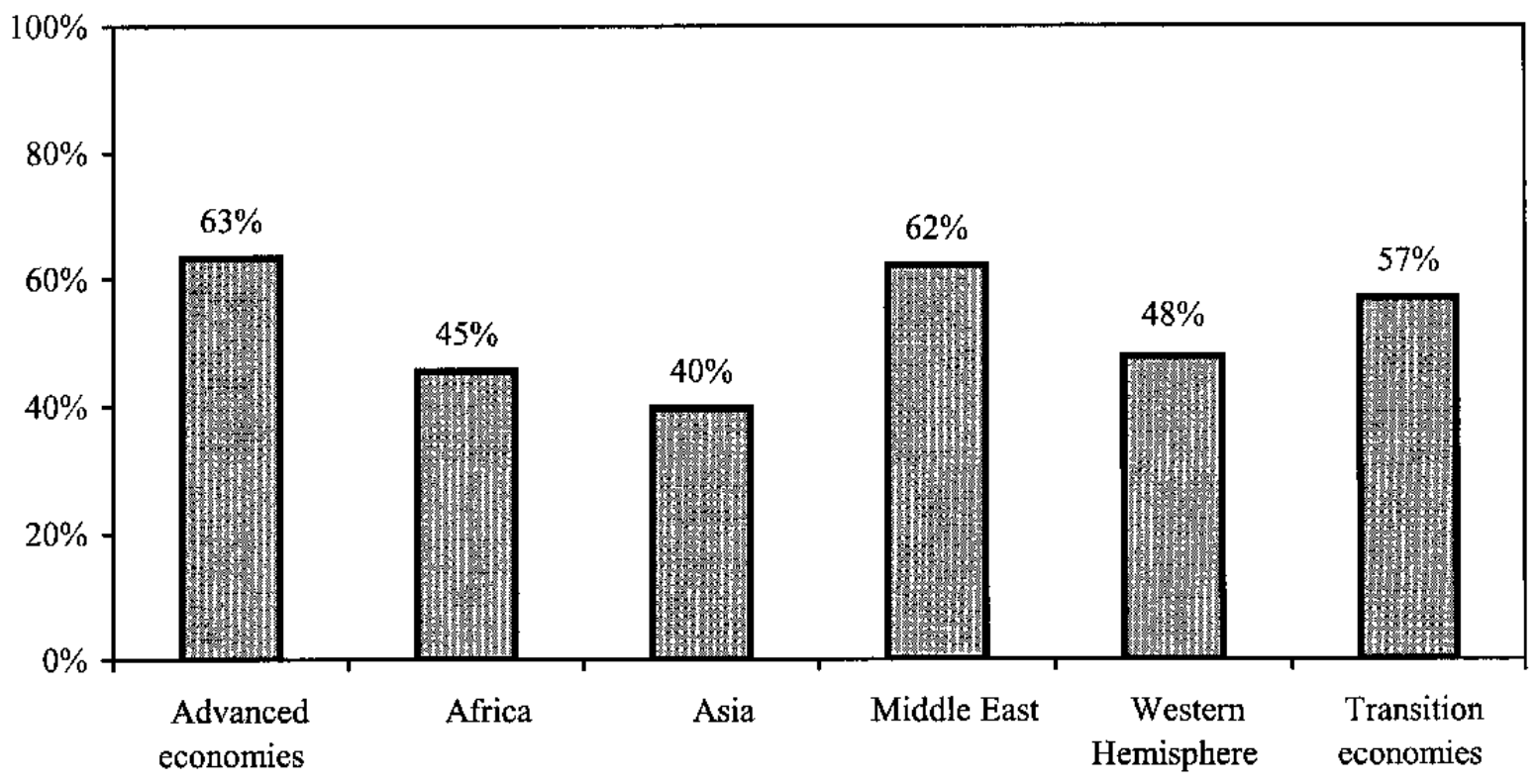

Source: IMF Survey on the Use, Compilation, and Dissemination of Macroprudential Indicators. 
Figure 2 summarizes the typical data collection practices of each country group. It suggests that advanced, Middle East, and transition economies have the most developed systems for collecting data on FSIs, enabling them to compile more than half of the indicators specified in the survey. Conversely, and perhaps surprisingly, Asian economies appear to have the least developed systems for collecting data on FSIs, enabling them to compile only 40 percent of the indicators. African and Western Hemisphere countries fare slightly better, collecting data on 45 and 48 percent of the indicators, respectively.

\section{Country practices}

Figure 3 shows the typical data collection practices of each country group by FSI category. ${ }^{16}$ Figure 4 presents supplementary information on data collection practices indicator-byindicator. ${ }^{17}$ The remainder of this section will use the information in these figures to highlight differences in the availability of FSIs in economies at different stages of development.

Also, banking-crisis countries might be more active than noncrisis countries in collecting data on FSIs perhaps owing to a heightened awareness of the benefits of monitoring financial vulnerability and perhaps to technical support from the IMF and other international and regional organizations. ${ }^{18}$ Therefore, this section examines the differences in collecting data on FSIs between these two groups. ${ }^{19}$

\section{Advanced economies}

Advanced economies collect data on more than half of the surveyed indicators. They collect data on more indicators in four FSI categories than other country groups (see Figure 3). In particular, they collect significantly more data on indicators of asset quality (borrowing institution) than other country groups, probably reflecting the generally well-developed statistical infrastructure in these countries.

\footnotetext{
${ }^{16}$ Figure 3 essentially combines Figures 1 and 2 and shows the percentage of indicators in each FSI category on which respondents collect data.

${ }^{17}$ Figure 4 shows the percentage of respondents in the country group that collect the relevant data series for constructing an FSI. A short hand abbreviation is used to identify each indicator in Figure 4. For example, MR2 refers to the second market risk indicator listed in Appendix II.

18 The Asian Development Bank has initiated a program among member countries to promote the compilation of FSIs. For further details see http://www.adb.org.

${ }^{19}$ Other factors such as country size or per capita GDP might also explain differences in country practices. Econometric work using a range of explanatory variables could be undertaken to test the robustness of any observed relationship between banking crises and national statistical practices. For instance, see Allum and Agca (2001) for an econometric analysis of the influences on data dissemination.
} 
Figure 3. Percentage of Indicators on Which Data Are Collected (Mean and Standard Deviation)

Capital Adequacy

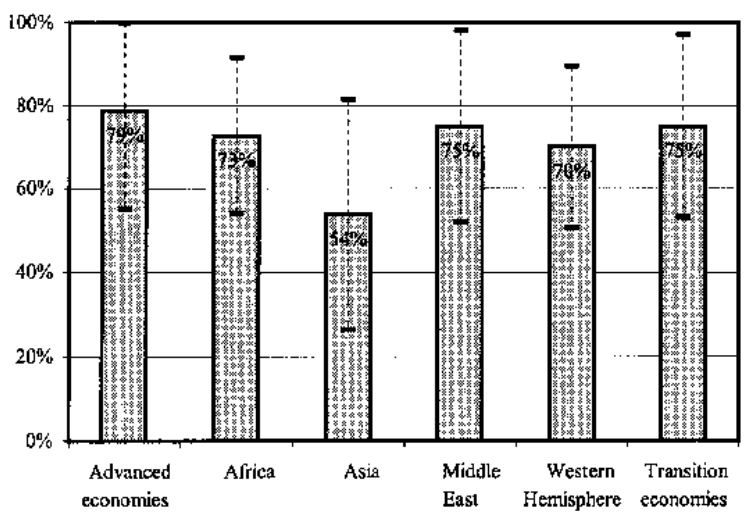

Asset Quality (Borrowing Institution)

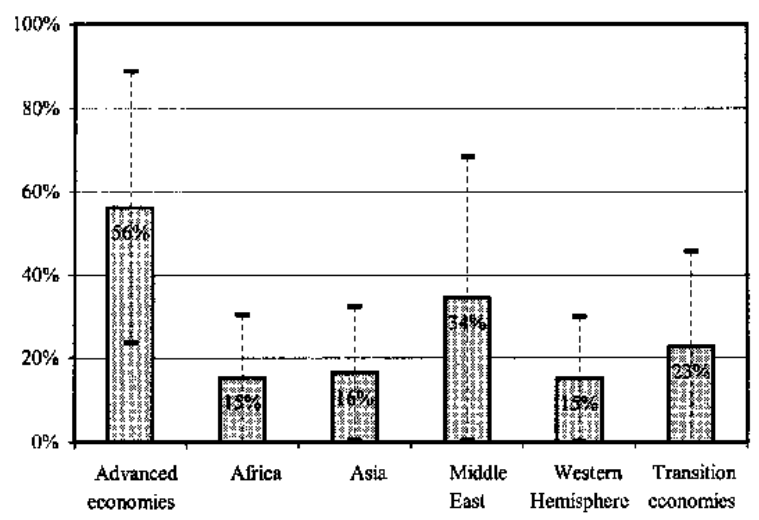

Liquidity

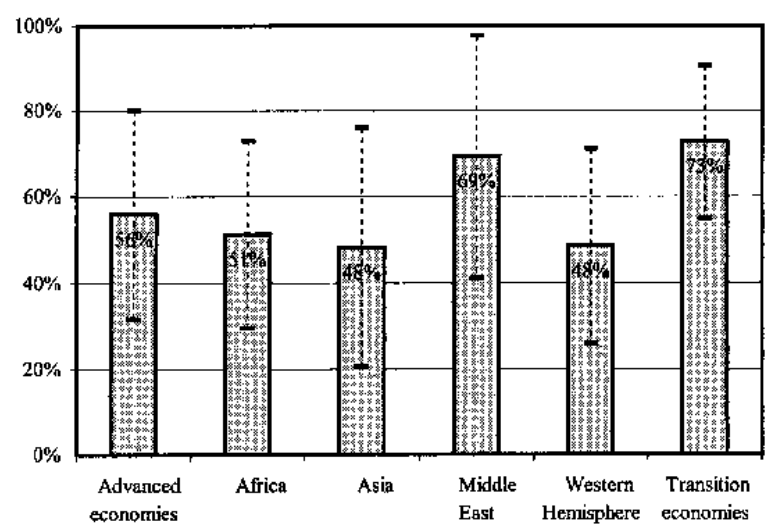

Asset Quality (Lending Institution)

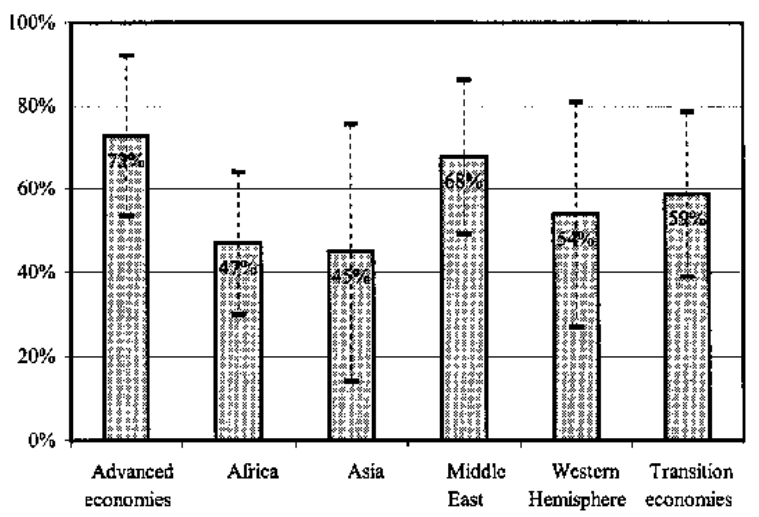

Profitability and Competitiveness

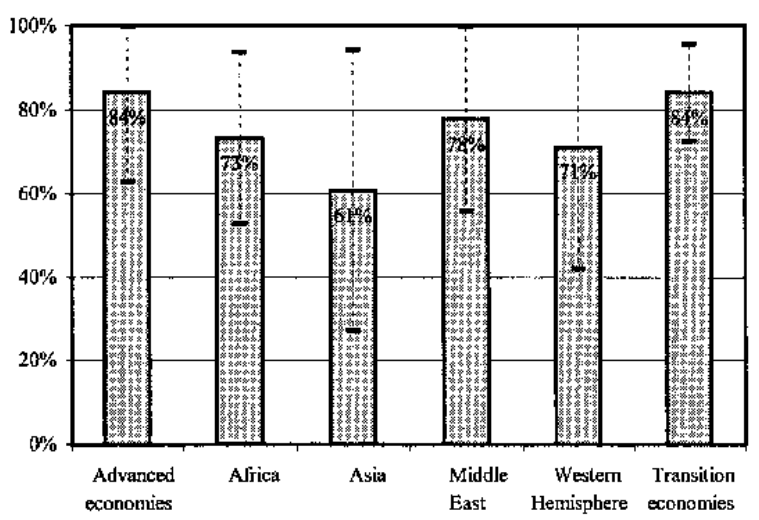

Market Risk

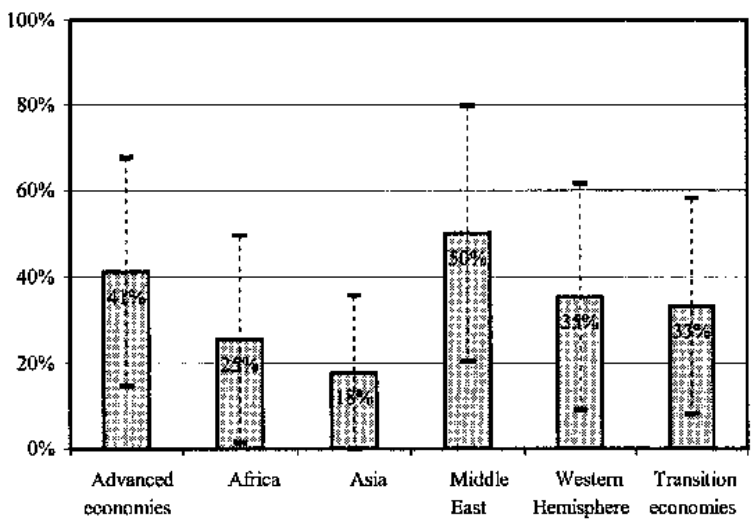

Source: IMF Survey on the Use, Compilation, and Dissemination of Macroprudential Indicators. 
Figure 4. Percentage of Survey Respondents Collecting Data on Individual Indicators

Advanced Economies

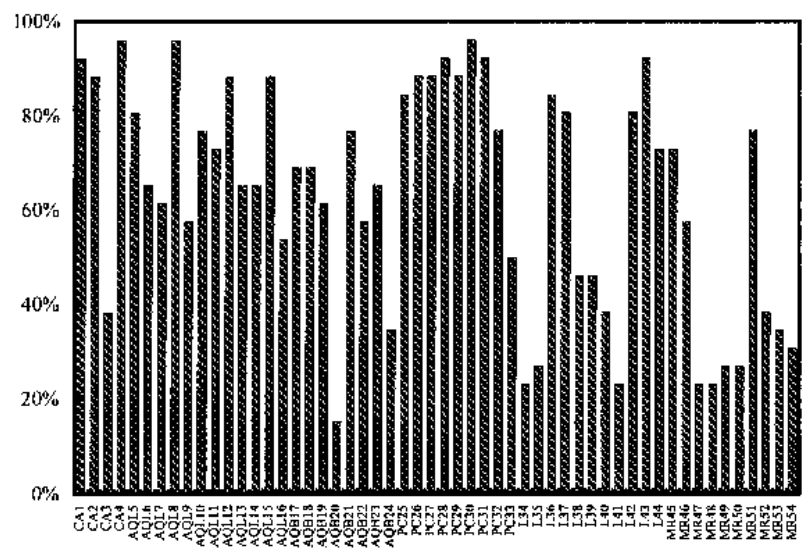

Asia

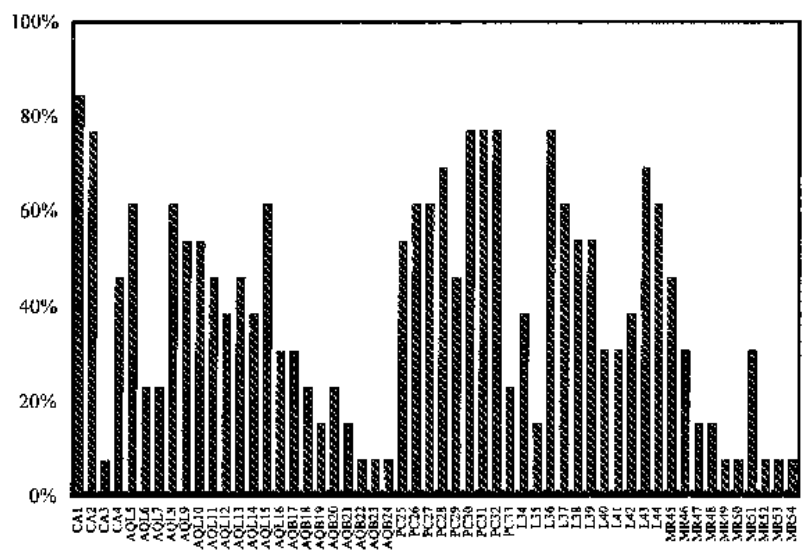

Western Hcmisphere

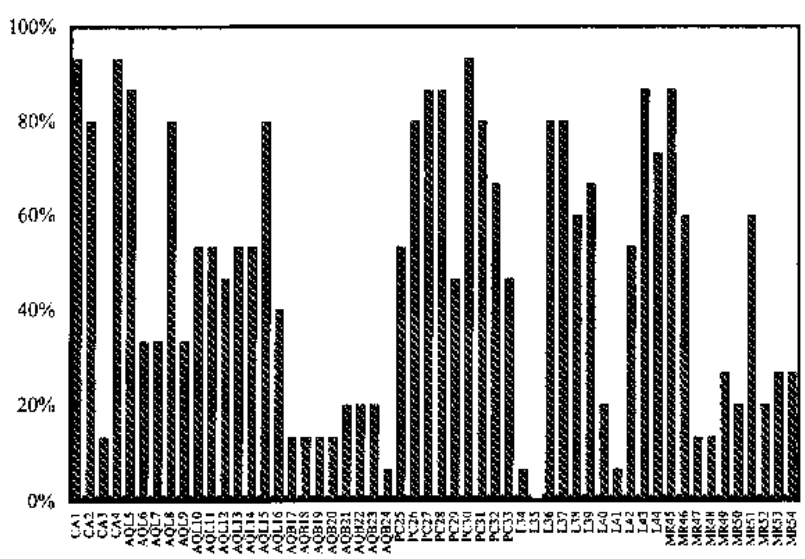

Africa

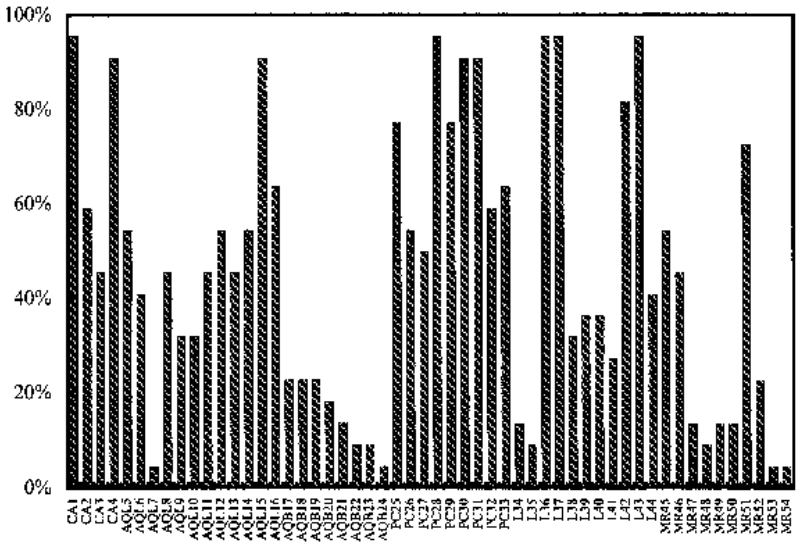

Middle East

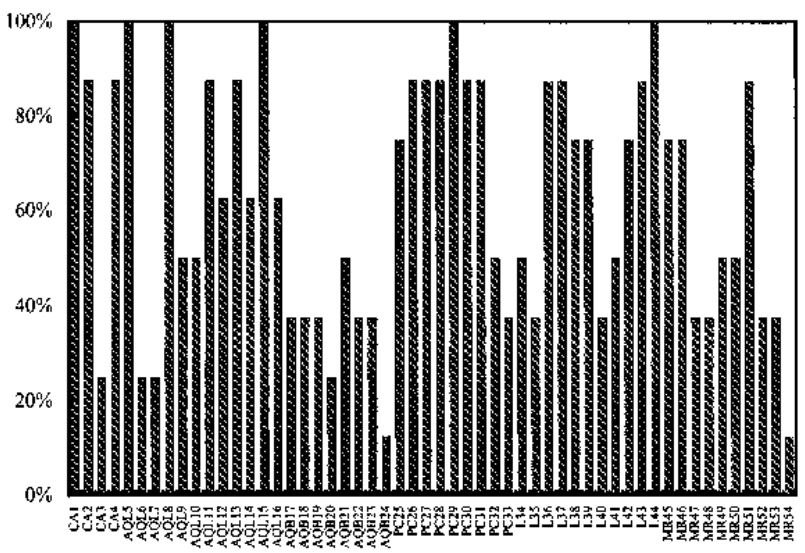

Transition Economies

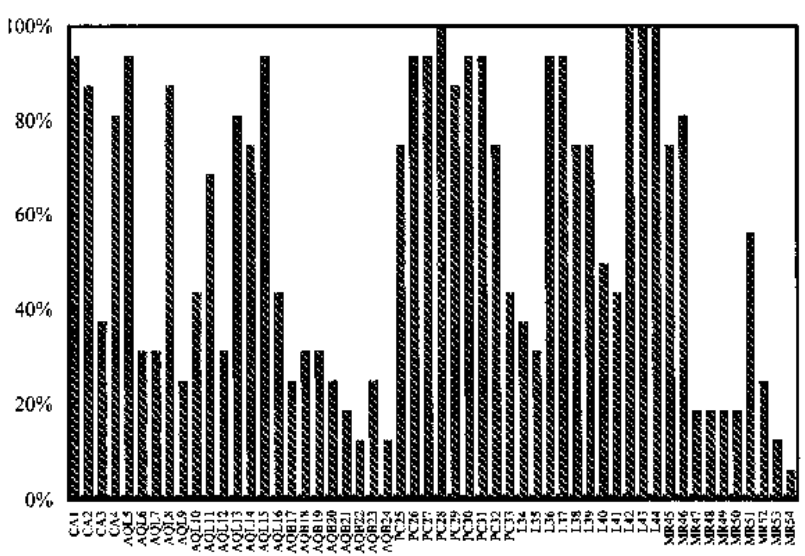

Source: IMF Survey on the Use, Compilation, and Dissemination of Macroprudential Indicators.

Note: The following short hand abbreviations are used to identify FSI categories: $\mathrm{CA}=$ Capital Adequacy; $\mathrm{AQL}=\mathrm{Asset}$ Quality (lending institution); $\mathrm{AQB}=$ Asset Quality (borrowing institution); $\mathrm{PC}=$ Profitability and Competitiveness; $\mathrm{L}=$ Liquidity; and MR = Market Risk. Indicators in each FSI category are identified by number. For example, MR2 refers to the second market risk indicator listed in Appendix II. 
Advanced economies collect data on a smaller number of liquidity indicators than transition and Middle Eastern economies. Figure 4 shows that advanced economies on average lag behind other countries in collecting FSI data series on liquidity indicators such as bid-ask spreads, turnover in the local T-bill market, average maturity of assets and liabilities, and the distribution of local-currency interbank rates.

Advanced economies collect data on fewer than half the market risk indicators. Although most advanced countries collect data on banks' gross and net foreign currency assets to own funds and gross equity position to own funds, about two-thirds of them do not collect data on the remaining seven market risk indicators specified in the survey (see Figure 4). Interestingly, users of financial soundness indicators in advanced economies deemed liquidity and market risk indicators less useful than other indicators, and several advanced country respondents commented that these indicators are sophisticated and difficult to construct to achieve precise results.

\section{Developing economies}

Perhaps surprisingly, Middle Eastern economies responding to the survey collect data on FSIs in a number similar overall to those collected by advanced countries. They also collect data on the largest number of market-risk indicators and on the second largest number of indicators of asset quality (lending institution), asset quality (borrowing institution), and liquidity (see Figure 3).

Nevertheless, Middle Eastern respondents are noticeably less active in collecting data on the following indicators (Figure 4). Only ten percent of respondents collect data on the number of applications for protection from creditors and net position in commodities to own funds. And only thirty percent of respondents collect data on the distribution of capital adequacy ratios, gross asset and liability positions in financial derivatives, and corporate net foreign currency exposure.

Developing economies outside the Middle East collect data on fewer indicators than advanced economies do in all FSI categories. They typically collect data on one-fifth of the asset quality (borrowing institution) indicators, one-third of the market risk indicators, and one-half of the liquidity and asset quality (lending institution) indicators. Within the developing country group, Asian economies collect data series on the least number of indicators in each FSI category (see Figure 3). In part this is explained by limited data collection in Asian countries that have not experienced a banking crises (see ahead).

Developing African and Western Hemisphere economies collect data on a similar number of the surveyed indicators, although Western Hemisphere economies collect data on marginally more asset quality (lending institution) and market risk indicators (Figure 3).

Western Hemisphere respondents are noticeably more active in collecting data on the following indicators (Figure 4). Ninety percent collect data on capital adequacy, leverage ratio, distribution of on-balance sheet assets, return on equity, net interest income to profits, operating costs to net interest income, gross foreign currency assets to own funds, and 
customer deposits to total (noninterbank) loans. Eighty percent collect data on Tier 1 capital, liquid assets to liquid liabilities, distribution of loans by sector, nonperforming loans to total assets, return on assets, and staff costs to operating costs.

African respondents are most active in collecting data on the following indicators. All collect data on the capital adequacy ratio, net interest income, liquid assets to liquid liabilities, and customer deposits to total (noninterbank) loans. Ninety percent collect data on the leverage ratio, gross nonperforming loans to total assets, operating costs to net interest income, and staff costs to operating costs.

\section{Transition economies}

Transition economies collect data on more than half of the surveyed indicators and collect data on the largest number of liquidity indicators. All transition economies collect data on at least 3 of the 11 indicators in this category (Figure 4). Allum and Agca (2001) find a similarly strong "transition effect" which they ascribe to political and institutional factors in these countries. In particular, even prior to transition, these countries placed a high priority on economic data. While much of this statistical effort was redundant after the collapse of state planning, the institutional reforms implemented during the transition extended to the statistical agencies. Many of them, as a matter of national pride, sought to bring their practices into line with those in market economies.

Nevertheless, transition economies are typically not very active in collecting data on the following indicators. Ten percent of them collect data on positions in commodities, mortgage debt to GDP, and the number of applications for protection from creditors. Twenty percent collect data on household debt to GDP, and average interest rate repricing and duration indicators. And 30 percent collect data on gross asset and liability positions in financial derivatives, loans for investment in commercial real estate, distribution of credit by country or region, and average interbank bid-ask spread for local currency deposits.

\section{Crisis countries}

Differences in the data collection practices of crisis and noncrisis countries are most apparent in Asia and the Western Hemisphere (Figure 5). Whereas crisis economies in Asia collect data on one-half of the surveyed indicators, noncrisis economies in Asia collect data on less than one-third of the indicators. In the categories of asset quality (borrowing institution) and market risk, crisis economies in Asia collect data on more than twice as many indicators as their noncrisis counterparts.

Crisis economies in the Western Hemisphere collect data on more indicators than their noncrisis counterparts in all FSI categories, especially profitability and competitiveness, capital adequacy, and liquidity. Nevertheless, crisis economies in the Western Hemisphere collect data on only 16 percent of the indicators of asset quality (borrowing institution). These indicators provide information on the debt-servicing capacity in the corporate and household sectors that can lead to burgeoning bad debt problems in the banking sector. 
Figure 5. Percentage of Indicators on Which Data Are Collected: Crisis and Noncrisis Countries

Advanced Economies

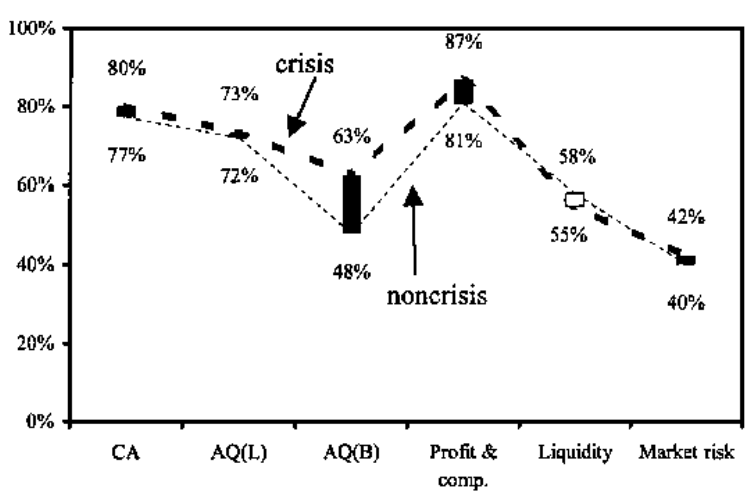

Asia

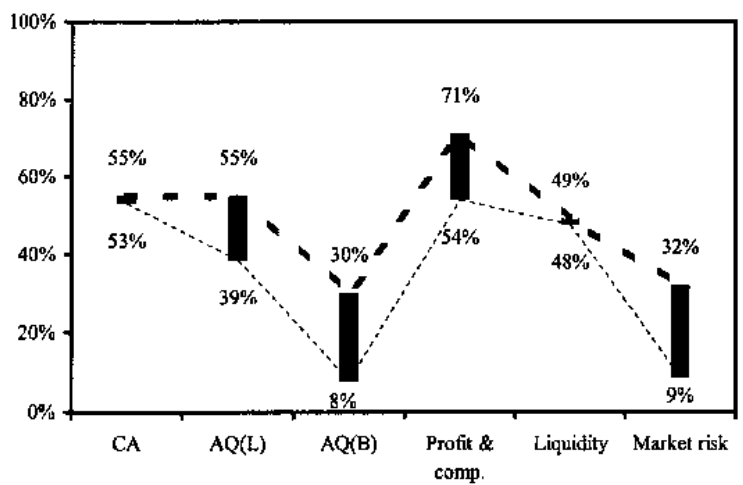

Western Hemisphere

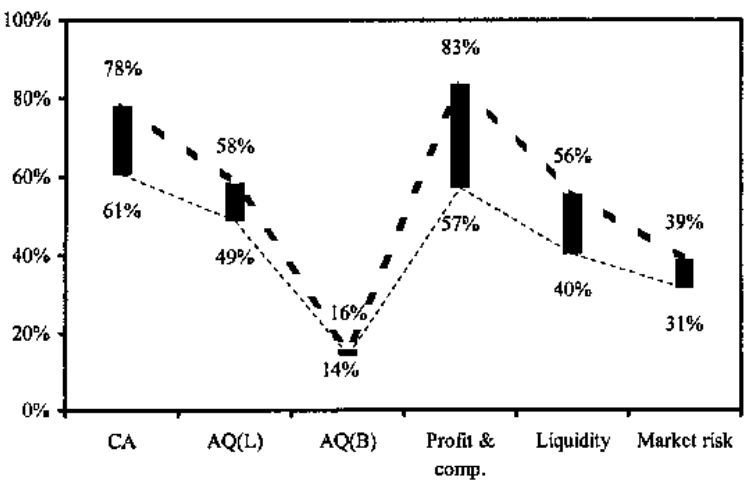

Africa

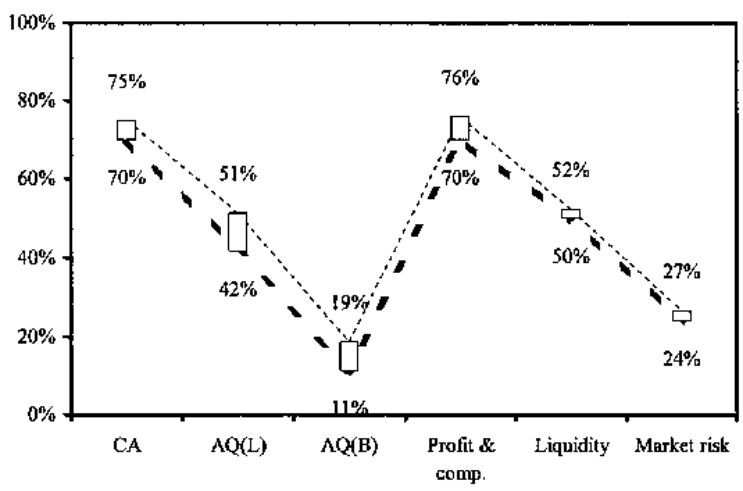

Middle East

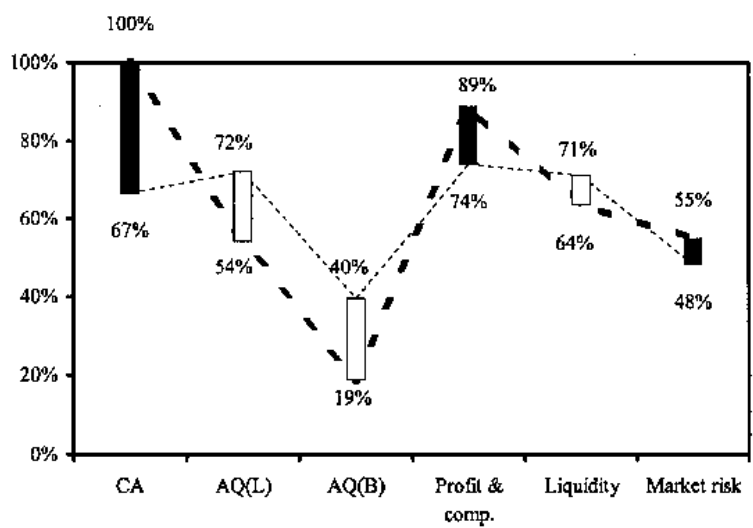

Transition Economies

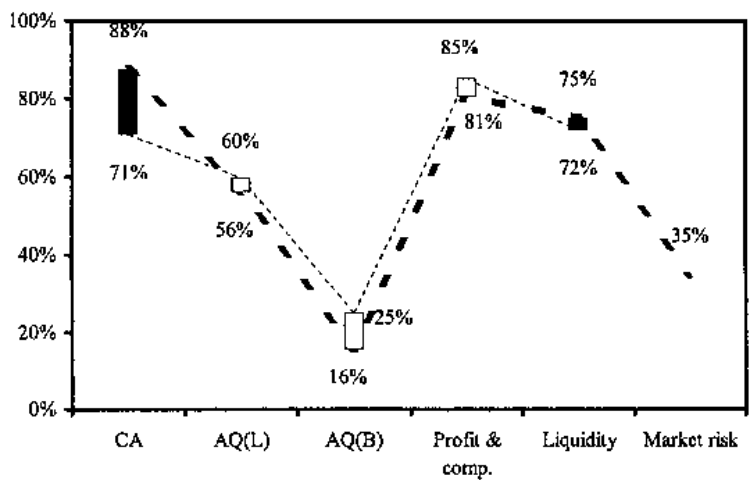

Source: IMF Survey on the Use, Compilation, and Dissemination of Macroprudential Indicators

Note: The following short hand abbreviations are used to identify FSI categories: $C A=$ Capital Adequacy; $A Q(L)=A s s e t$ Quality (lending institution); $\mathrm{AQ}(\mathrm{B})=$ Asset Quality (bottowing institution); and Profit. and comp. = Profitability and Competitiveness. 
There is limited evidence that crisis countries in other country groups collect data on a larger number of indicators than noncrisis countries. Figure 5 shows the following:

- Crisis countries with advanced economies collect data on more indicators of asset quality (borrowing institution) than their noncrisis counterparts and collect data on about the same number of indicators in the remaining FSI categories.

- Crisis countries in the Middle East collect data on more indicators in the categories of capital adequacy, profitability and competitiveness, and market risk than their noncrisis counterparts and collect data on fewer indicators in the remaining FSI categories.

- Crisis countries with transition economies collect data on more indicators in the category of capital adequacy than their noncrisis counterparts and collect data on fewer indicators on asset quality (borrowing institution).

- Crisis countries in Africa collect data on marginally fewer indicators than their noncrisis counterparts, in all FSI categories.

\section{Worldwide data collection}

Because of the voluntary nature of the survey, drawing inferences about the global collection of data on FSIs is not straightforward. Countries active in compiling FSIs are more likely to have responded to the survey, resulting in a self-selection bias. Furthermore, there is a lower degree of confidence in estimating the global availability of data on FSIs for transition and developing economies than for advanced economies because of their lower response rates (see Table 1).

To illustrate, Figure 6 shows upper- and lower-bound estimates of the global availability of data for compiling FSIs. The upper-bound estimate is the mean number of FSIs for which survey respondents (the sample population) collect data. In effect, the estimate assumes no selection bias in the survey results. The lower-bound estimate assumes that nonrespondents collect data on none of the FSIs specified in the survey - that is, complete selection bias is assumed. As shown by the lower-bound estimate in Figure 6, the global availability of data may be as low as one-quarter of the FSIs specified in the survey rather than the one-half indicated by the upper-bound. However, given that most countries collect monetary statistics and some prudential data, the lower-bound estimate may be overly pessimistic for FSIs drawn from bank balance sheets and income statements. 
Figure 6. Upper and Lower Bound Estimates of the Global Collection of Data on FSIs

Advanced Economies

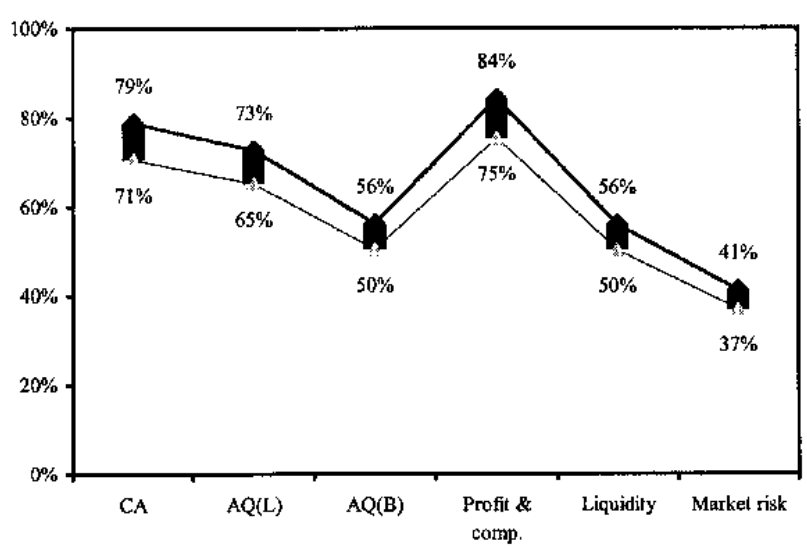

Asia

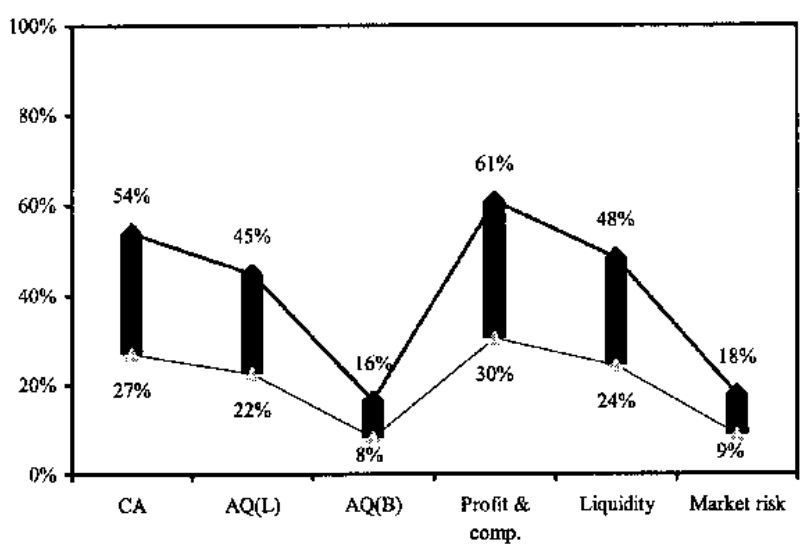

Western Hemisphere

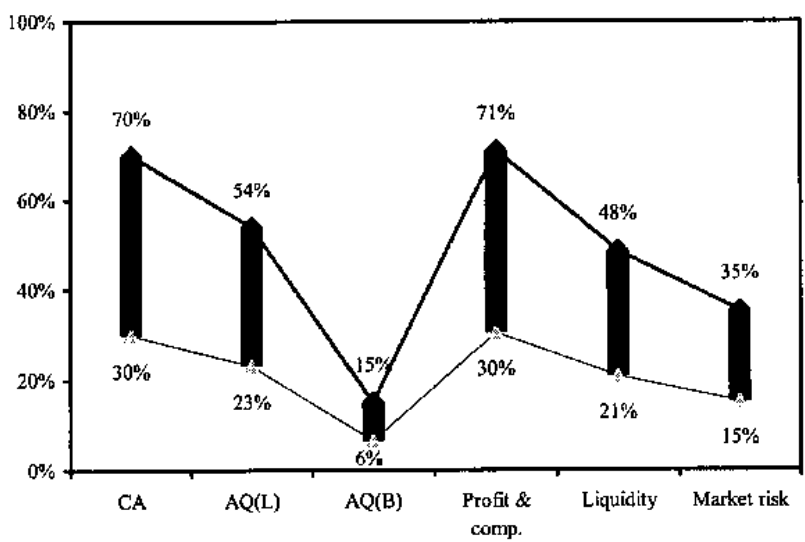

Africa

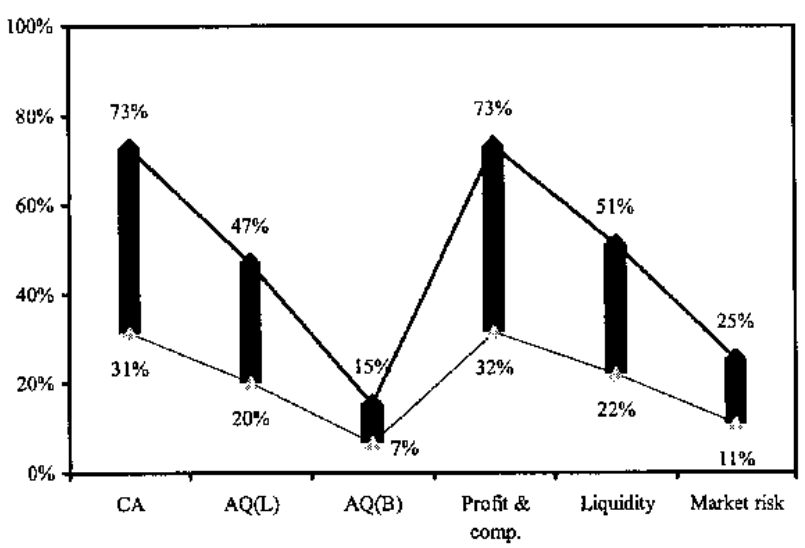

Middle East

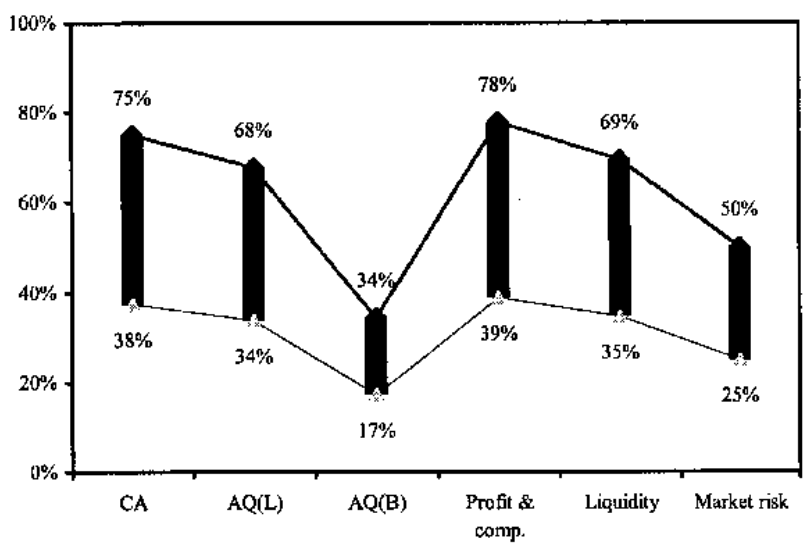

Transition Economies

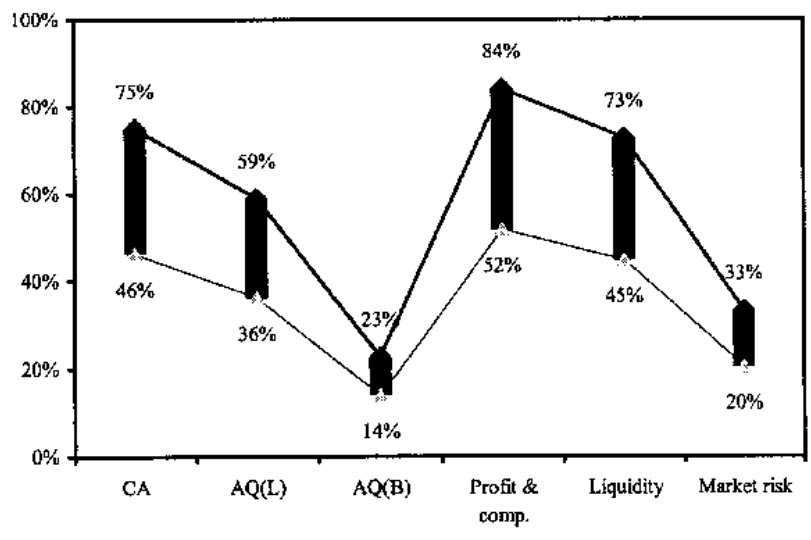

Source: IMF Survey on the Use, Compilation, and Dissemination of Macroprudential Indicators.

Note: The following short hand abbreviations are used to identify FSI categories: $\mathrm{CA}=$ Capital Adequacy; $\mathrm{AQ}(\mathrm{L})=\mathrm{Asset}$ Quality (lending institution); $A Q(B)=$ Asset Quality (borrowing institution); and Profit. and comp. = Profitability and Competitiveness. 


\section{B. Compilation of FSI Ratios}

As noted earlier, whether national authorities use the data they collect to compile FSI ratios may indicate how, and perhaps whether, they use them in financial soundness analysis. ${ }^{20}$ Figure 7 shows the percentage of surveyed FSIs on which countries collect data together with the percentage of indicators for which they compile ratios. Figure 8 shows the resulting proportion of collected data series that are used to compile ratios. The following salient points can be noted:

- There is scope for each country group to compile a larger number of ratios in each FSI category using available data sources. On average, advanced economies use 60 percent of available data to compile ratios; African countries use 57 percent; Asian countries use 36 percent; Middle Eastern countries use 53 percent; Western Hemisphere countries use 54 percent; and transition economies use 43 percent.

- Asian countries compile far fewer ratios from available data in each FSI category (except for asset quality (borrowing institution)) than other country groups, but significant differences exist between Asian countries that have and have not experienced a banking crisis (see ahead).

- On average, countries are most likely to use data collected on capital adequacy indicators to compile ratios (68 percent of available data is used to compile ratios), while countries are least likely to use data collected on liquidity and market risk indicators to compile ratios (40 percent of available data is used to compiled ratios). Countries use about 50 percent of data collected on asset quality and on profitability and competitiveness indicators to compile ratios.

These findings may point to differences in the way countries use data collected on indicators in their financial soundness analysis. The findings may also show that some countries are further along in extracting information content from the data by compiling ratios, as well as analyzing underlying data series.

In this connection, there are some noteworthy differences between crisis and noncrisis countries in compiling FSI ratios (see Figure 9), as noted below:

- Banking-crisis countries in the Western Hemisphere use a larger proportion of collected data to compile indicators in the form of ratios than their noncrisis counterparts, particularly for indicators on asset quality (borrowing institution) and market risk. Similarly, crisis countries with advanced economies, and in Africa, use a larger proportion of their collected data to compile indicators in ratio form than their noncrisis counterparts.

${ }^{20}$ Analysis of both the ratio and underlying data series would of course be optimal. 
Figure 7. Percentage of Indicators on Which Data Are Collected and FSI Ratios Compiled

Capital Adequacy

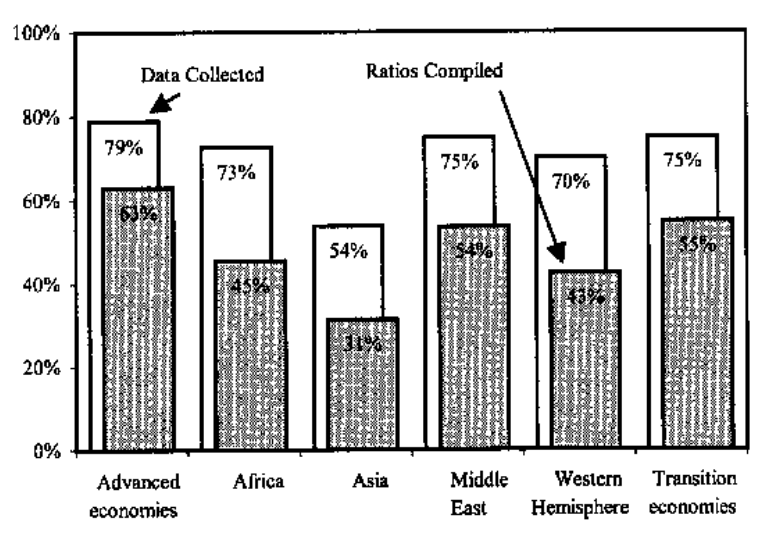

Asset Quality (Borrowing Institution)

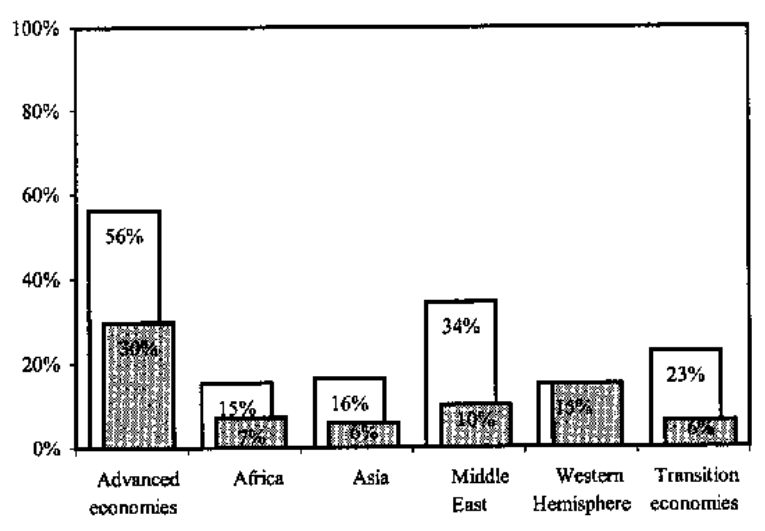

Liquidity

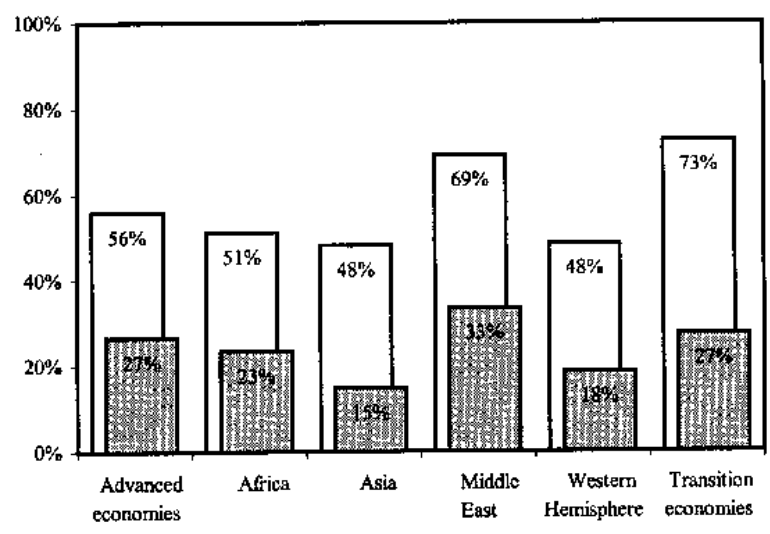

Asset Quality (Lending Institution)

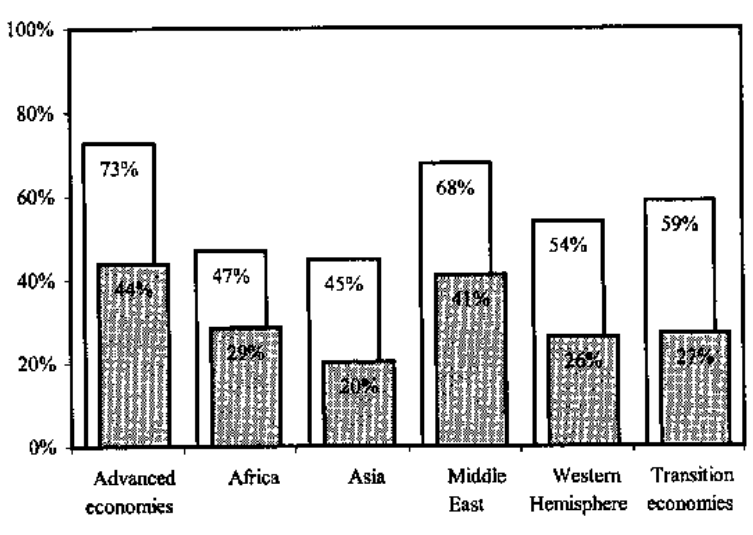

Profitability and Competitiveness

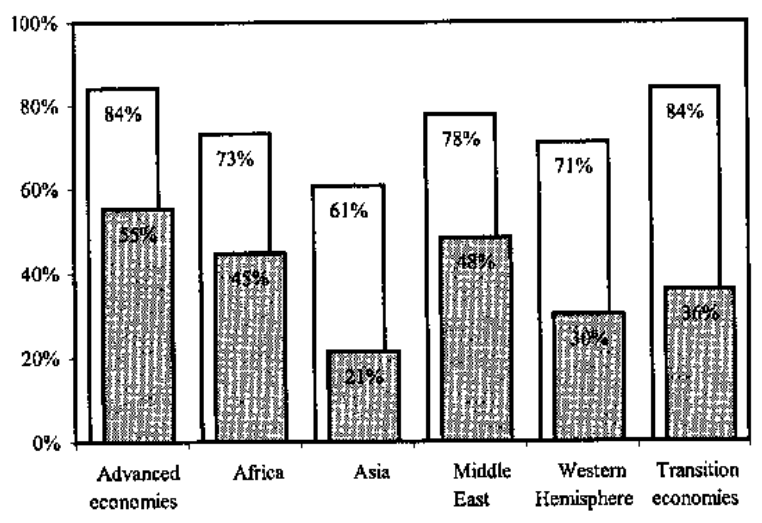

Market Risk

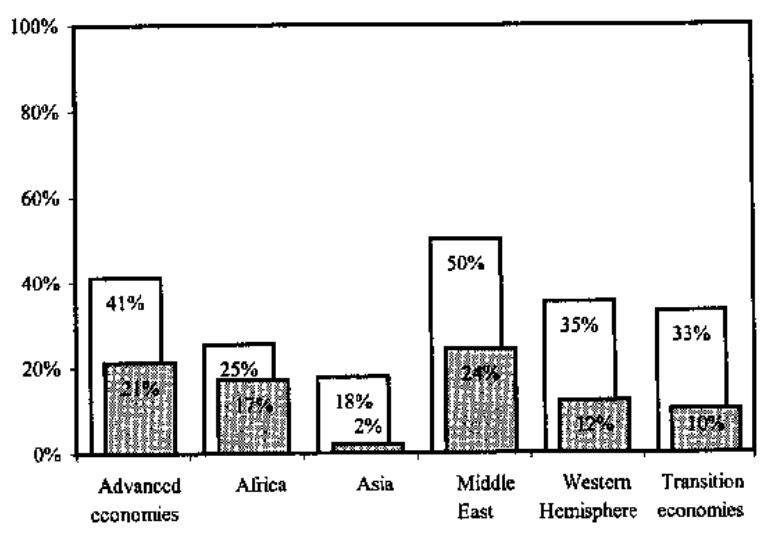

Source: IMF Survey on the Use, Compilation, and Dissemination of Macroprudential Indicators. 
Figure 8. Proportion of Collected Data Used to Compile FSI Ratios

Capital Adequacy

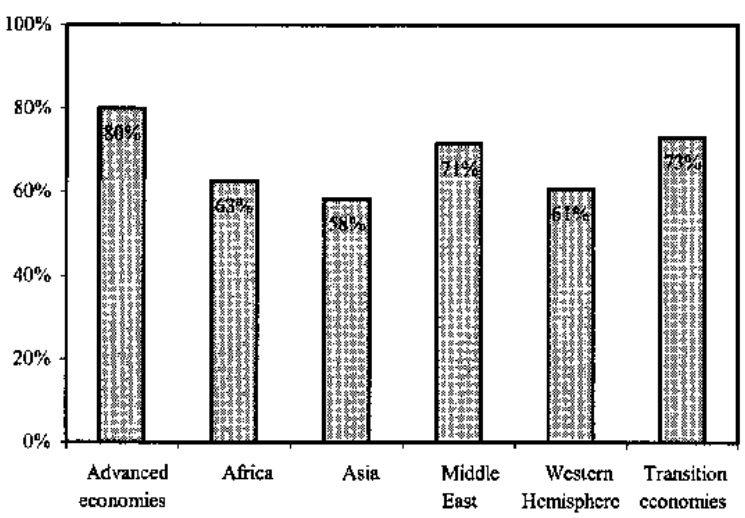

Asset Quality (Borrowing Institution)

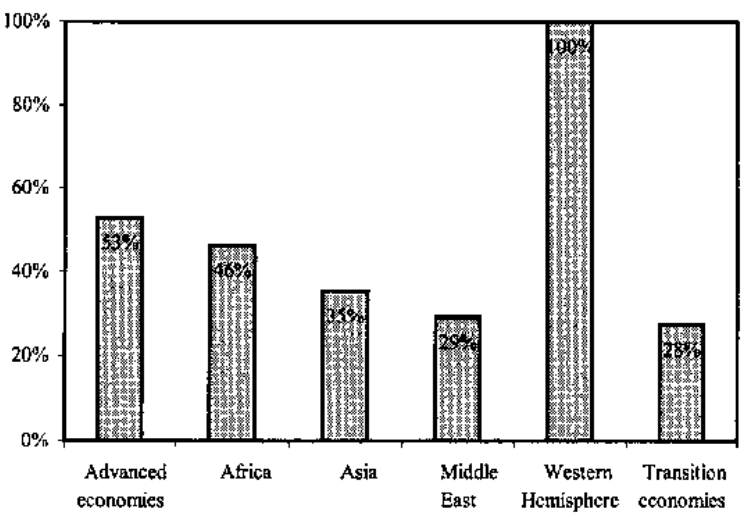

Liquidity

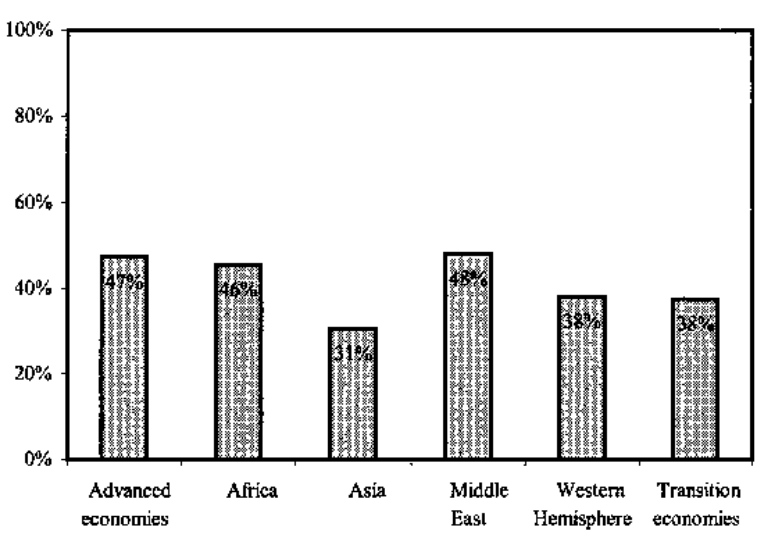

Asset Quality (Lending Institution)

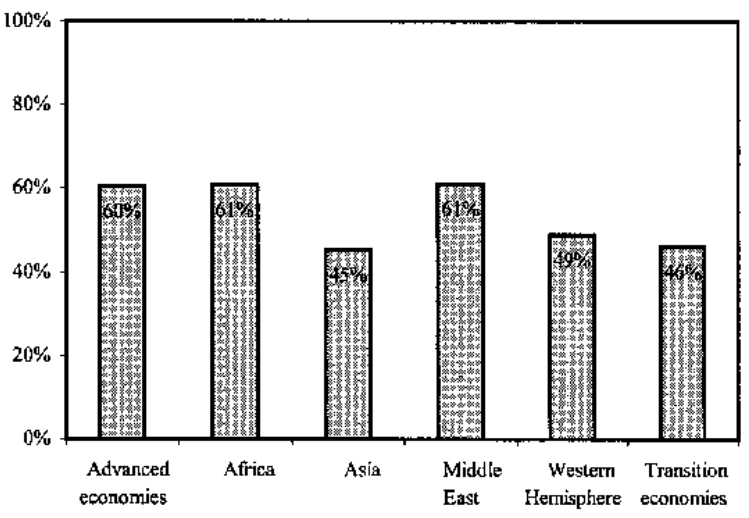

Profitability and Competitiveness

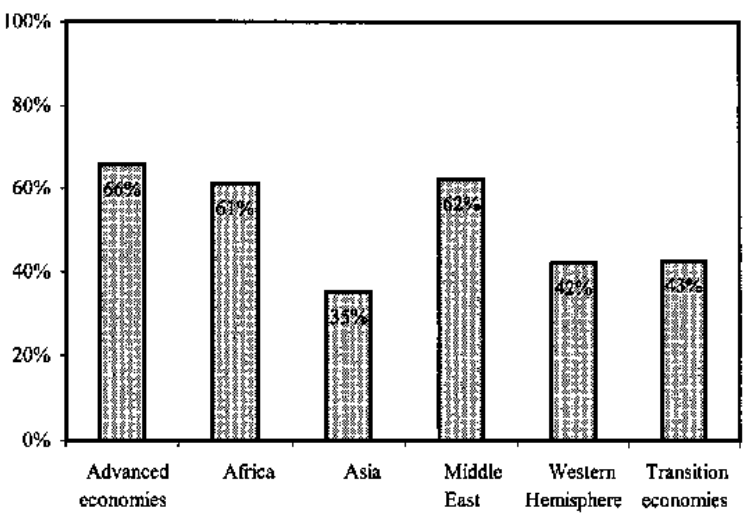

Market Risk

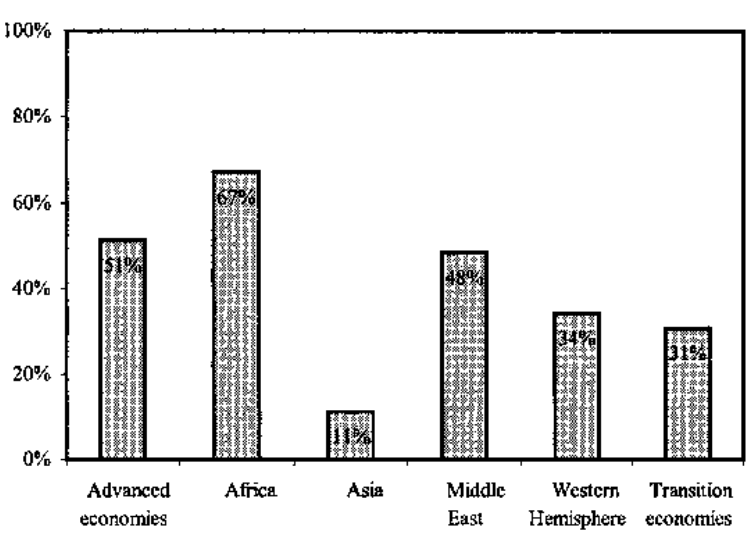

Source: IMF Survey on the Use, Compilation, and Dissemination of Macroprudential Indicators. 
Figure 9. Proportion of Collected Data Used to Compile FSI Ratios in Crisis and Noncrisis Economies

Advanced Economies

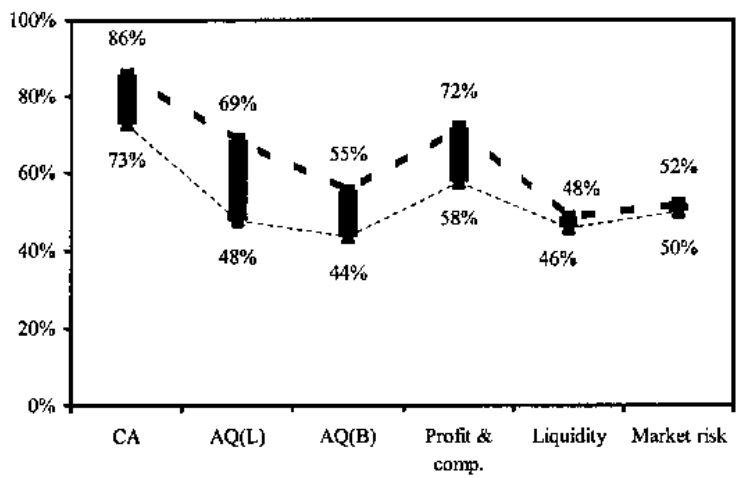

Asia

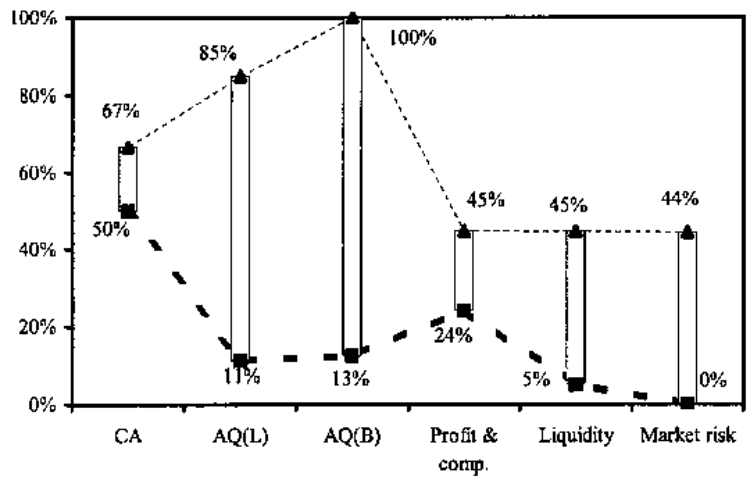

Western Hemisphere

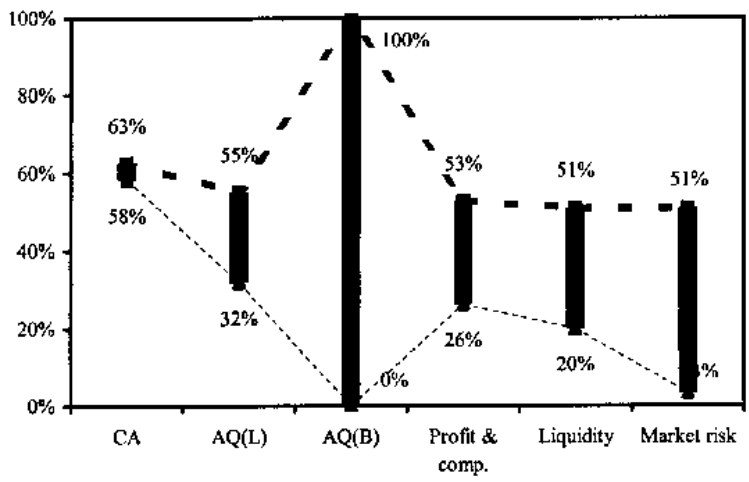

Africa

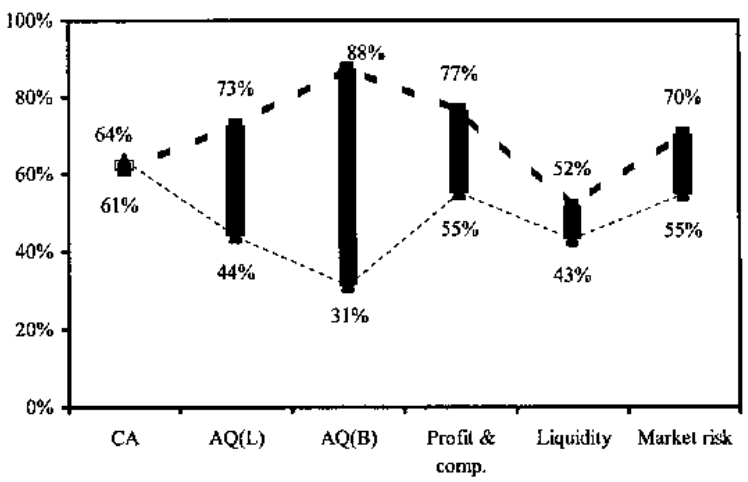

Middle East

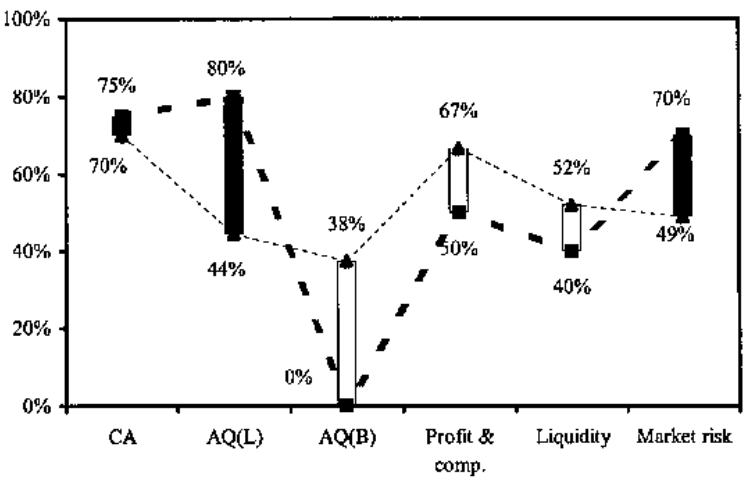

Transition Economies

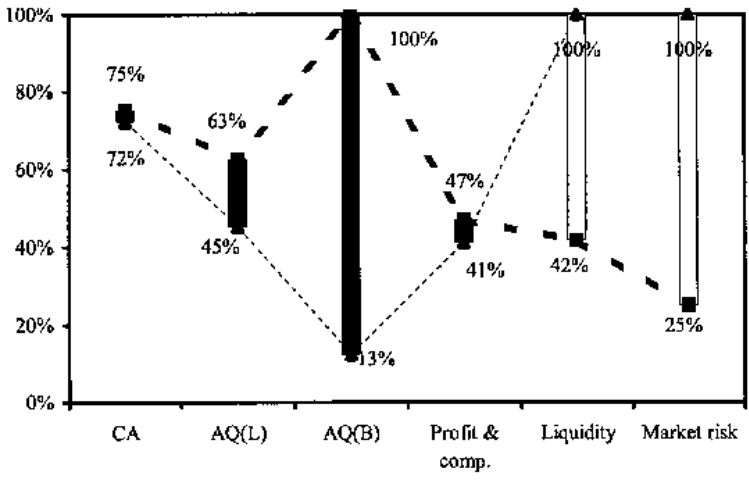

Source: IMF Survey on the Use, Compilation, and Dissemination of Macroprudential Indicators.

Note: The following short hand abbreviations are used to identify FSI categories: $\mathrm{CA}=$ Capital Adequacy; $\mathrm{AQ}(\mathrm{L})=\mathrm{Asset}$ Quality (lending institution); $\mathrm{AQ}(\mathrm{B})=$ Asset Quality (borrowing institution); and Profit. and comp. $=$ Profitability and Competitiveness. 
- By contrast, Asian crisis countries use a smaller proportion of their collected data to compile indicators in the form of ratios than their noncrisis counterparts. Thus, although Asian crisis countries collect data on a much larger number of indicators than their noncrisis counterparts (see above), much of the data is not put into ratio form for use in their financial vulnerability analysis.

- A mixed picture emerges for Middle Eastern and transition economies, with crisis countries using a larger proportion of their collected data to compile indicators in the form of ratios in some FSI categories and a smaller proportion in others. Middle Eastern crisis countries compile proportionately more indicators in the form of ratios than noncrisis countries in the categories of asset quality (lending institution) and market risk. Transition crisis countries compile proportionately more indicators in the form of ratios than noncrisis countries in the categories on asset quality (lending institution) and asset quality (borrowing institution).

\section{Public Availability of FSIs}

Because views differ on how markets react to information, countries approach disseminating data, maintaining confidentiality, and providing assessments on the condition of the domestic banking sector with different perspectives. Some countries suggest that markets might react adversely to negative news about banking sector soundness. Other countries disseminate a wide range of information in the belief that these data lead to informed decisions by market participants. In short, national authorities may not make available (disseminate) to the public some of the data collected on FSIs-collection of data on FSIs does not equate with public availability of these data. This section explores country practices in disseminating the data they collect, and the next section explores country eagerness to disseminate data to the public. 


\section{A. Dissemination of Data on FSIs}

A comparison of the data collected and disseminated on FSIs reveals that official agencies make a much smaller data set available to the public than they collect (Figure 10). Survey respondents typically disseminate less than half of the 54 indicators specified in the survey. ${ }^{21}$ Official agencies in Asia provide the public with only 19 percent of the surveyed indicators. African, Middle Eastern, and Western Hemisphere countries provide 28 percent of the surveyed indicators to the public, and advanced and transition economies provide 41 percent to the public. The number of indicators disseminated also varies by FSI category, as shown in Figure 11. In addition, data that are disseminated on FSIs are not usually available from a single agency website or publication and are more often dispersed and difficult to locate.

Figure 10: Comparison of Percentage of FSIs Disseminated and Percentage of FSIs Collected

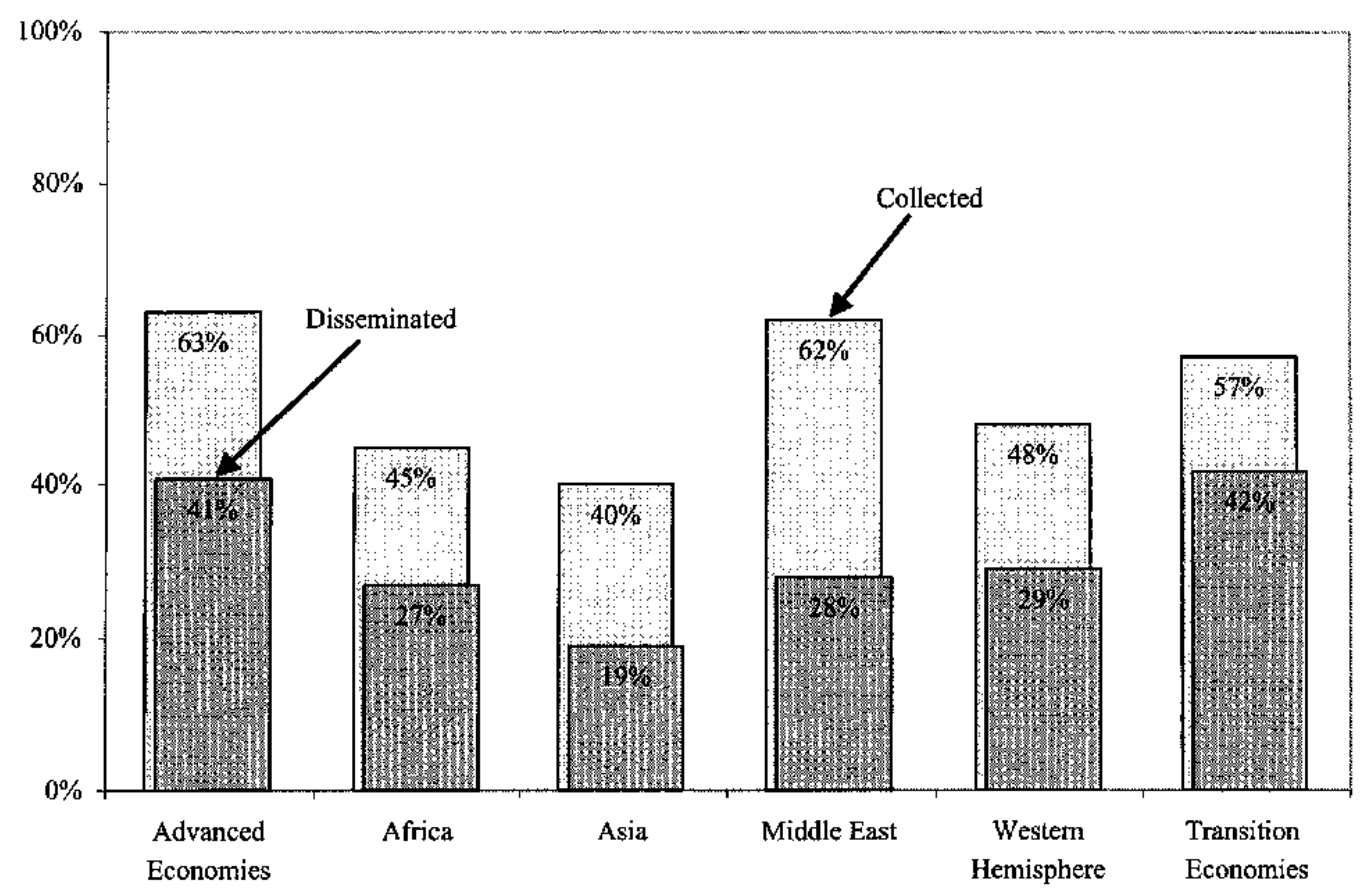

${ }^{21}$ For brevity, an indicator is described as disseminated if either the ratio is disseminated or the underlying data series are disseminated. 
Figure 11. Comparison of Data Collection and Dissemination Practices, by FSI Category

Advanced Economics

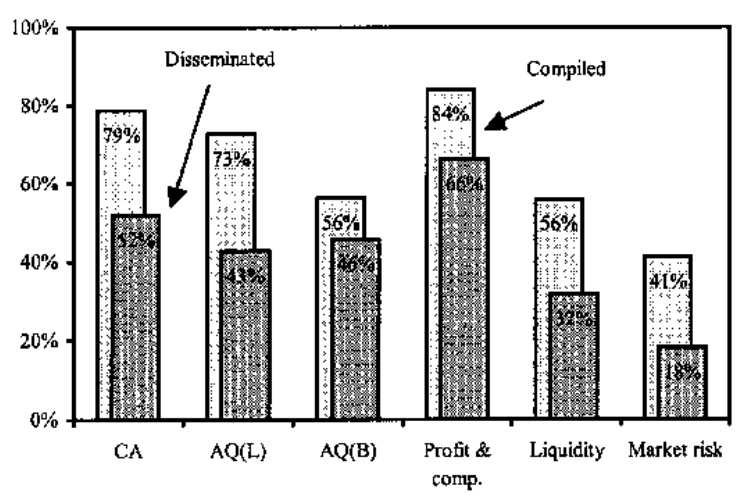

Asia

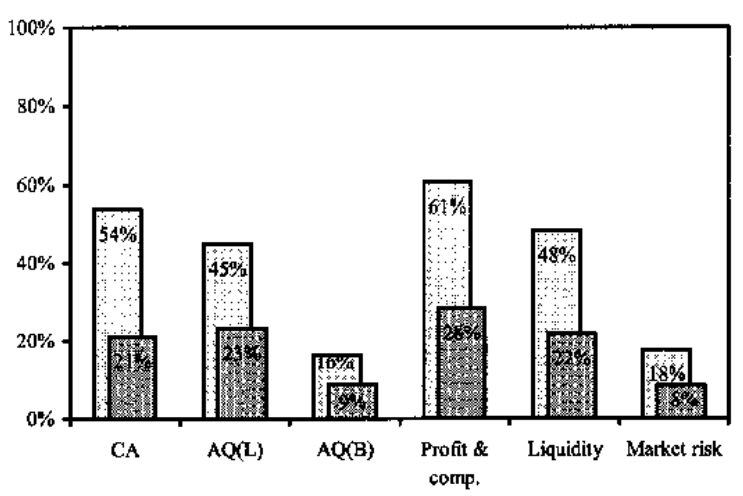

Western Hemisphere

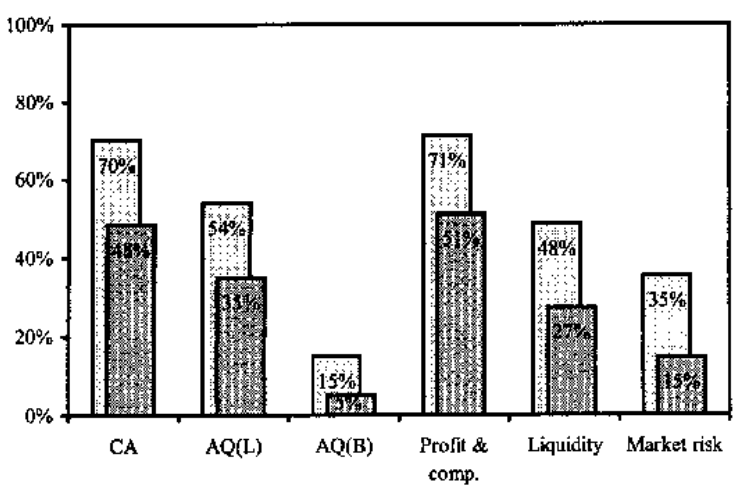

Africa

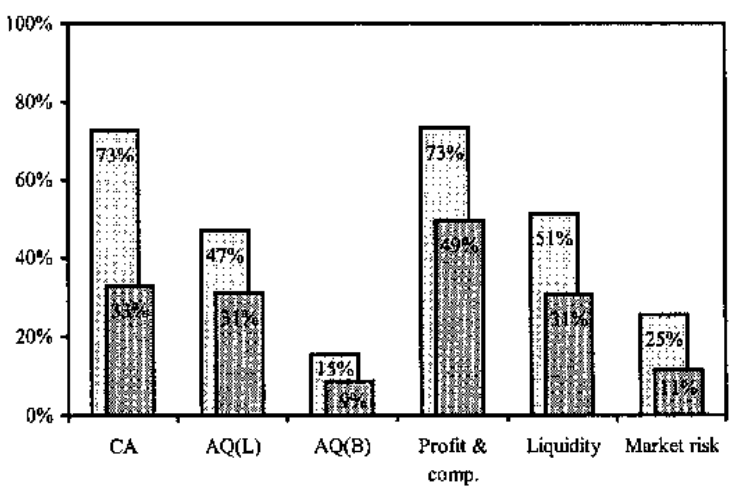

Middle East

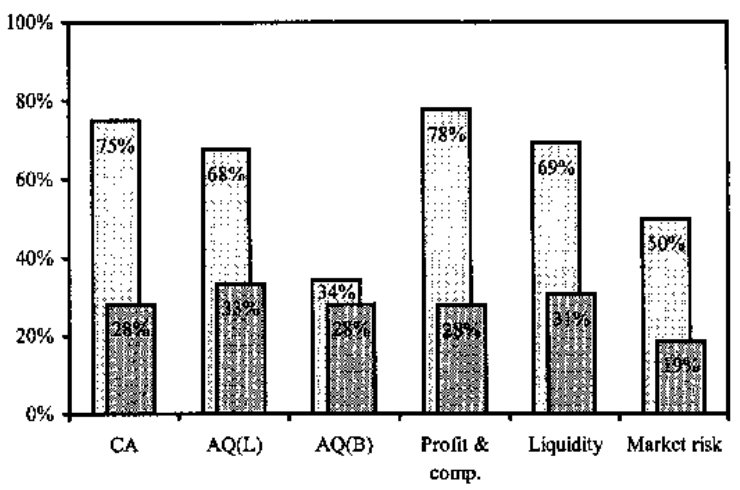

Transition Economies

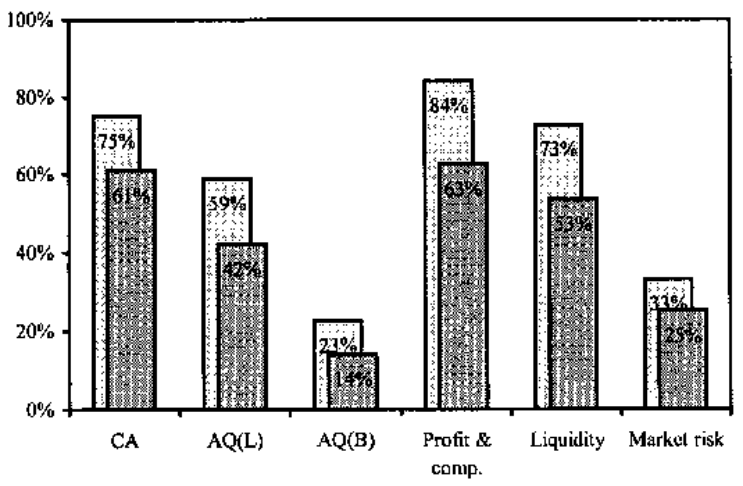

Source: IMF Survey on the Use, Compilation, and Dissemination of Macroprudential Indicators.

Note: The following short hand abbreviations are used to identify FSI categories: $C A=$ Capital Adequacy; $A Q(L)=A s s e t$ Quality (lending institution); $\mathrm{AQ}(\mathrm{B})=$ Asset Quality (botrowing institution); and Profit. and comp. = Profitability and Competitiveness. 
Figure 12. Percentage of Indicators on Which Data Are Disseminated:

Crisis and Noncrisis Countries

Advanced Economies

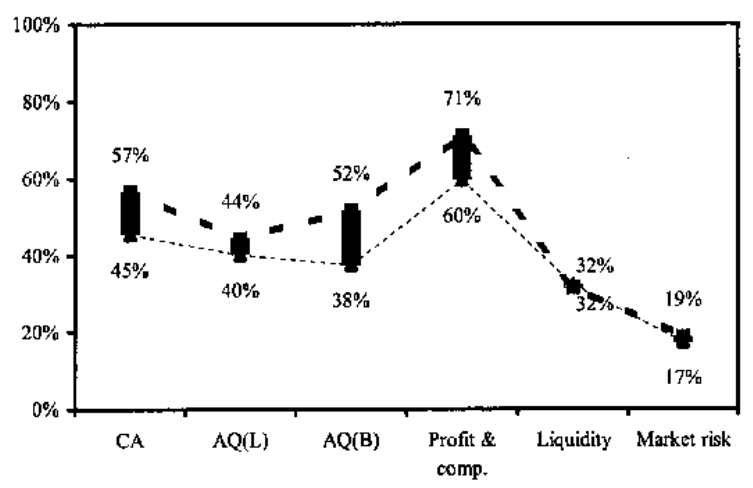

Asia

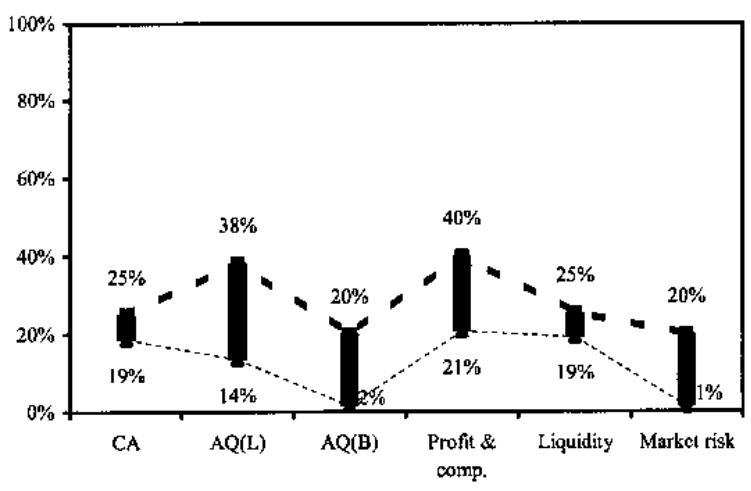

Western Hemisphere

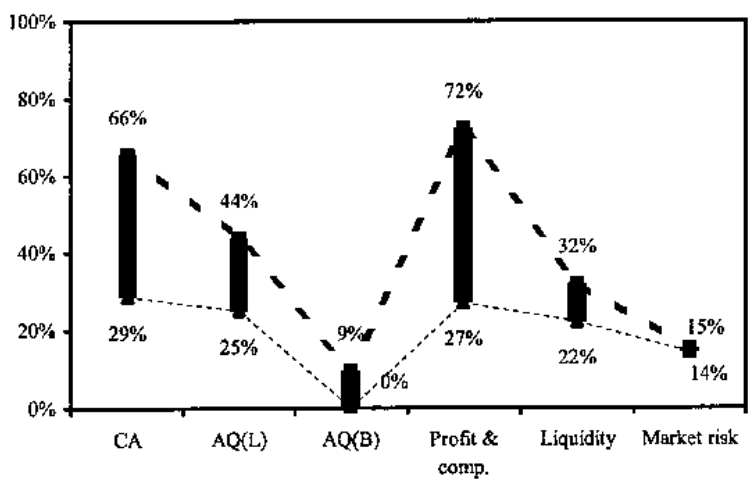

Africa

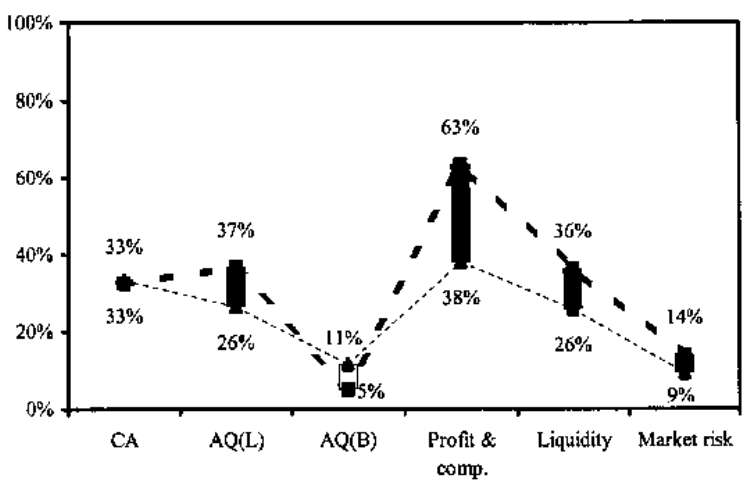

Middle East

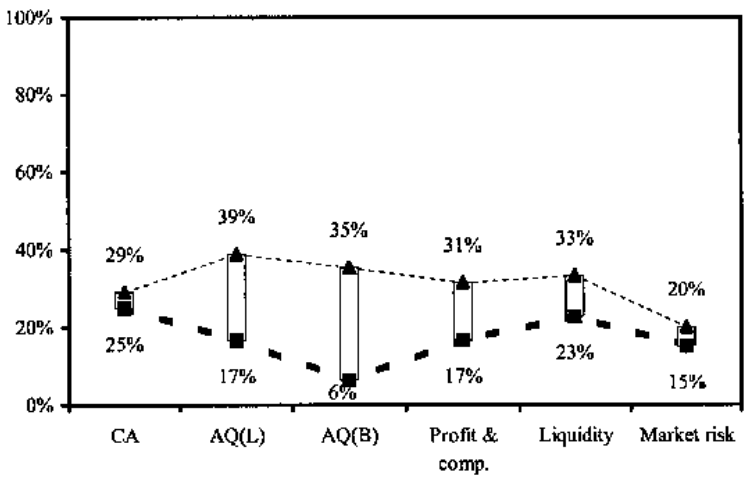

Transition Economies

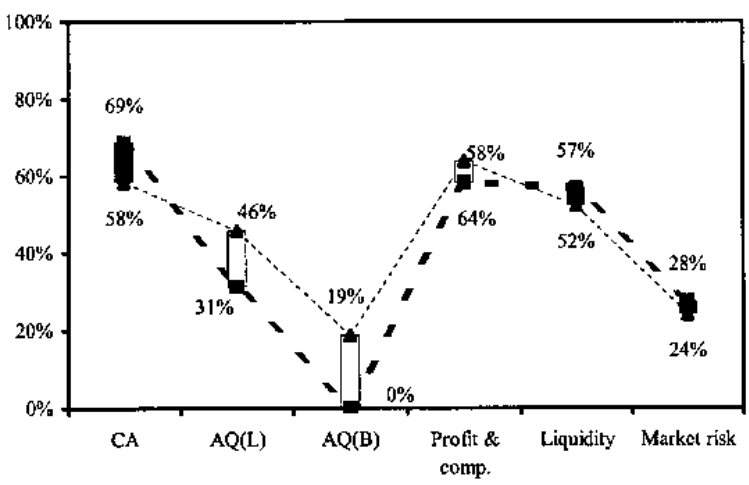

Source: IMF Survey on the Use, Compilation, and Dissemination of Macroprudential Indicators.

Note: The following short hand abbreviations are used to identify FSI categories: $\mathrm{CA}=$ Capital $\mathrm{Adequacy} ; \mathrm{AQ}(\mathrm{L})=\mathrm{Asset}$ Quality (lending institution); $\mathrm{AQ}(\mathrm{B})=$ Asset Quality (borrowing institution); and Profit. and comp. $=$ Profitability and Competitiveness. 
The survey responses suggest there are some differences in the number of FSIs disseminated by crisis and noncrisis economies (see Figure 12). Asian, Western Hemisphere, advanced, and African crisis economies disseminate more indicators in almost every FSI category than their noncrisis counterparts.

Asian crisis economies disseminate data on at least twice as many indicators as noncrisis economies in the categories of asset quality, profitability and competitiveness, and market risk. Similarly, Western Hemisphere crisis economies disseminate data on at least twice as many indicators as noncrisis economies in the categories of capital adequacy and profitability and competitiveness.

By contrast, crisis countries with transition economies disseminate fewer indicators than their noncrisis counterparts in three FSI categories. Moreover, Middle Eastern crisis economies disseminate fewer indicators than their noncrisis counterparts in all FSI categories.

The number of FSIs that countries disseminate is of course constrained by the number of indicators on which they collect data series-countries with more developed data collection systems have the potential to disseminate a wider range of FSIs to the public. Nevertheless, as shown earlier in Figures 10 and 11, this potential is not always realized with some country groups more reluctant (or less eager) than others to disseminate the data they collect. The eagerness of countries to disseminate the data they collect is explored next.

\section{B. Eagerness to Disseminate}

\section{Overview}

By comparing the number of FSIs on which countries disseminate data with the number of FSIs on which they collect data, analysts can gauge the eagerness of survey respondents to disseminate official data on FSIs to the public. Figure 13 shows the eagerness of respondents to disseminate official data on FSIs in terms of the proportion of collected data they disseminate.

Overall, transition economies are the most eager to disseminate data on FSIs (they disseminate 74 percent of the data they collect). This is followed by advanced economies (disseminating 65 percent of collected data) and African and Western Hemisphere countries (disseminating 60 percent of collected data). Asian and the Middle Eastern countries appear to be the most reluctant to disseminate FSIs, providing the public with less than half of the indicators on which they collect data. However, differences between crisis and noncrisis countries are significant in this regard, especially for the Asian country group (see ahead). 
Figure 13. Proportion of Indicators on Which Data Are Collected and Disseminated, by Country Group

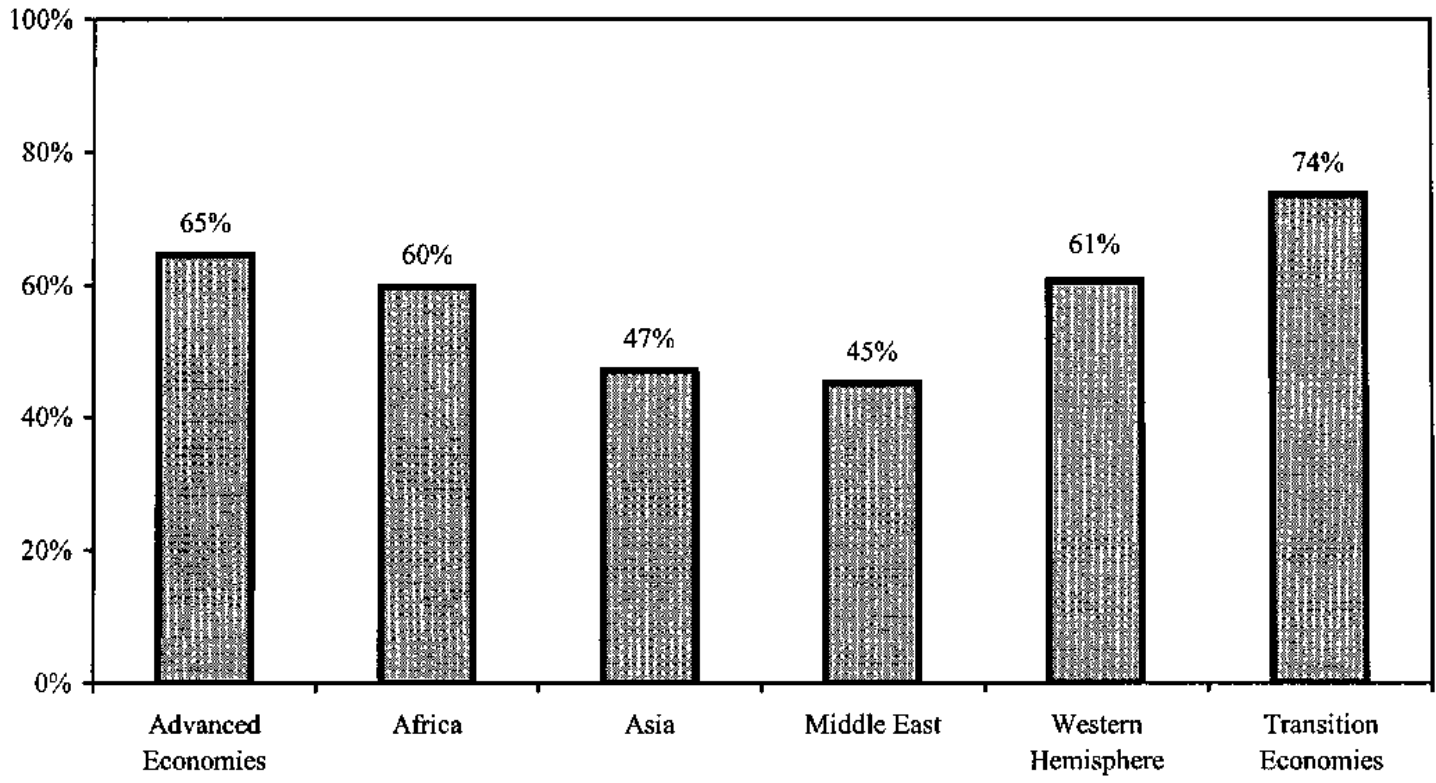

Figure 14. Proportion of Indicators on Which Data Are Collected and Disseminated, by FSI Category

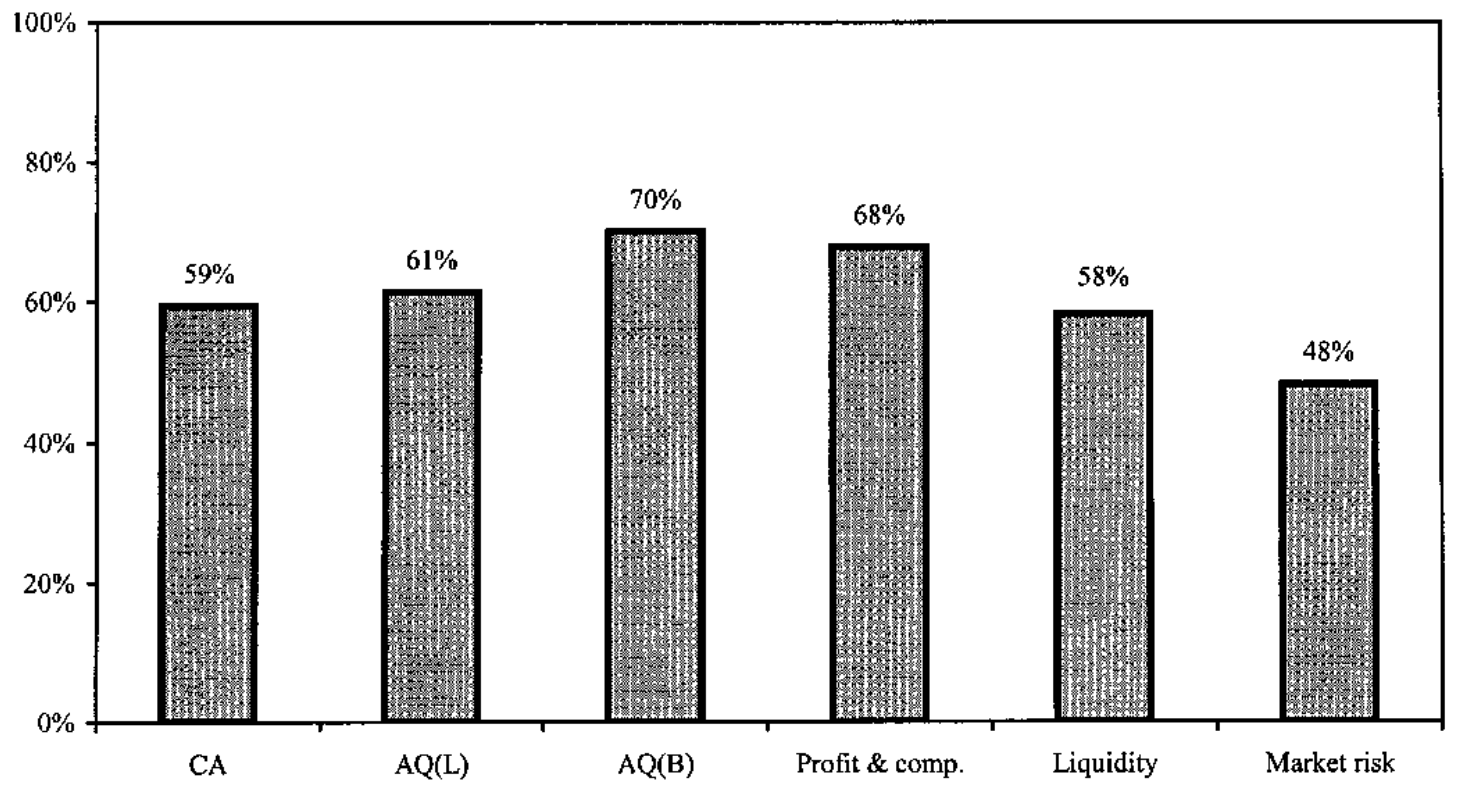

Source: IMF Survey on the Use, Compilation, and Dissemination of Macroprudential Indicators.

Note: The following short hand abbreviations are used to identify FSI categories: $\mathrm{CA}=$ Capital Adequacy; $\mathrm{AQ}(\mathrm{L})=$ Asset Quality (lending institution); $\mathrm{AQ}(\mathrm{B})=$ Asset Quality (borrowing institution); and Profit. and comp. $=$ Profitability and Competitiveness. 
Figure 14 shows the eagerness to disseminate collected data by type of FSI. It suggests respondents are typically least eager to disseminate data on indicators of market risk (they disseminate half of collected data). Respondents are typically most eager to disseminate data on indicators of assets quality (borrowing institution) and profitability and competitiveness (they disseminate about 70 percent of collected data). They disseminate about 60 percent of collected data on indicators of capital adequacy, asset quality (lending institution) and liquidity.

The remainder of this section takes a closer look at the eagerness of respondents to disseminate indicators within each of the six categories of FSI and assesses the eagerness of crisis and noncrisis countries to disseminate.

\section{FSI categories}

\section{Capital adequacy}

Transition economies are the most eager to disseminate data collected on capital adequacy indicators, while African, Asian, and Middle Eastern economies are the least eager (see Figure 15). Nevertheless, all Asian respondents disseminate data collected on the distribution of capital adequacy ratios. By contrast, none of the Middle Eastern or Western Hemisphere respondents disseminate data collected on this indicator (see Figure 16).

Respondents to the survey are typically most eager to disseminate data on the leverage ratio-75 percent of respondents disseminate the data they collect on this indicator. They are typically least eager to disseminate data on the distribution of capital adequacy ratios -40 percent of respondents disseminate the data they collect on this indicator (see Figure 16). It is noteworthy that respondents in one or more country groups are typically more eager than respondents in advanced countries to disseminate data on each of the individual indicators of capital adequacy.

\section{Asset quality (lending institution)}

Transition countries are most eager to disseminate data collected on asset quality (lending institution) indicators, followed by African and Western Hemisphere countries. Middle Eastern and Asian economies are the least eager to disseminate data collected on this category of FSI.

Respondents are typically most eager to disseminate data on the distribution of loans and credits, including for investment in commercial and residential real estate-between 70 and 80 percent of respondents disseminate data collected on these indicators (see Figure 16). An exception is that only 20 percent of Middle Eastern countries disseminate data collected on the distribution of credit by country or region. Between 70 and 80 percent of respondents also typically disseminate data collected on indicators of nonperforming loans and provisions. Two notable exceptions are that only 40 percent of Asian and Middle Eastern respondents disseminate data collected on nonperforming loans. 
Figure 15. Proportion of Indicators on Which Data Are Collected and Disseminated

Capital Adequacy

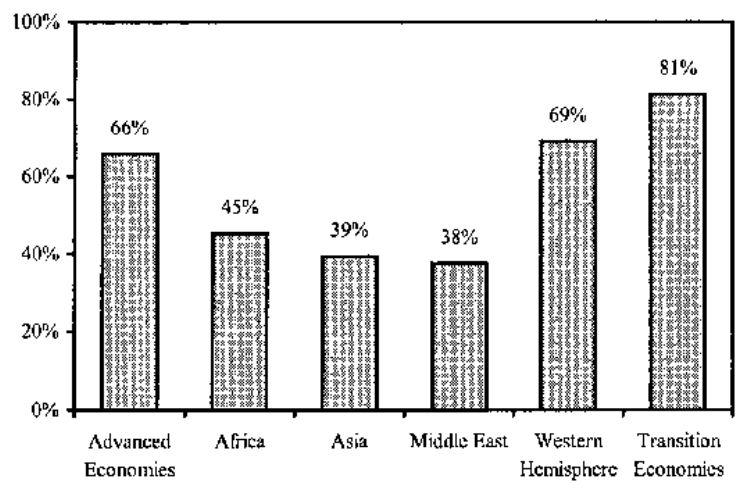

Asset Quality (borrowing institution)

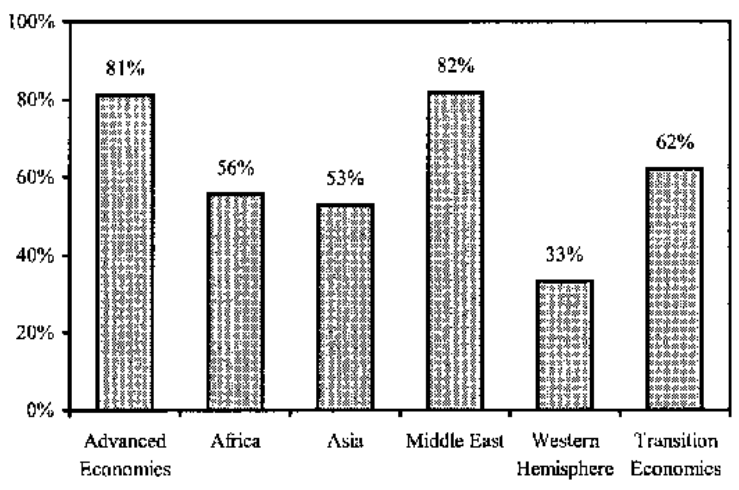

Liquidity

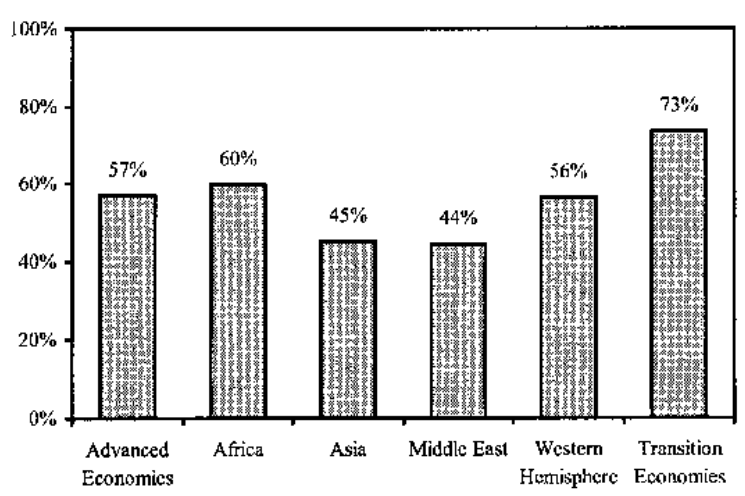

Asset Quality (lending institution)

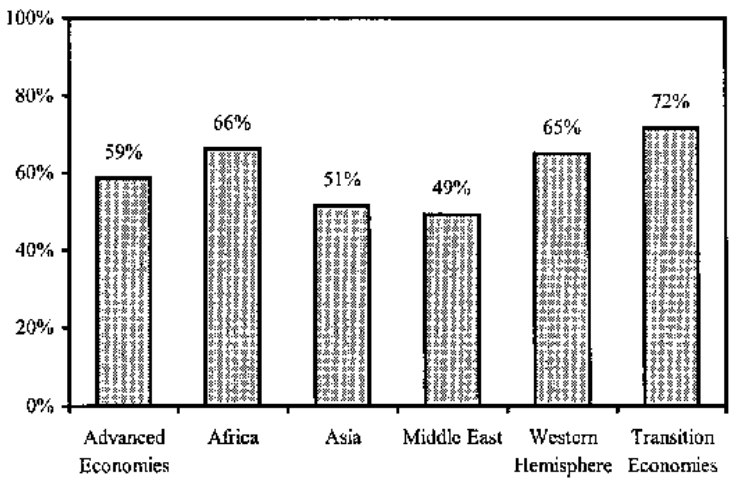

Profitability and Competitiveness

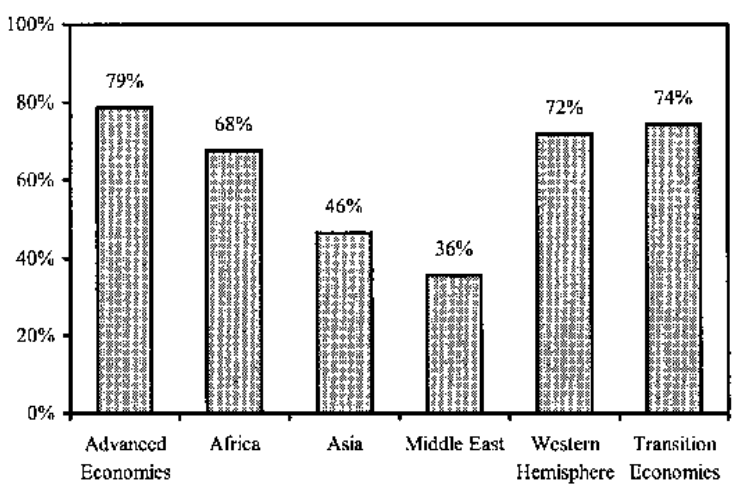

Market Risk

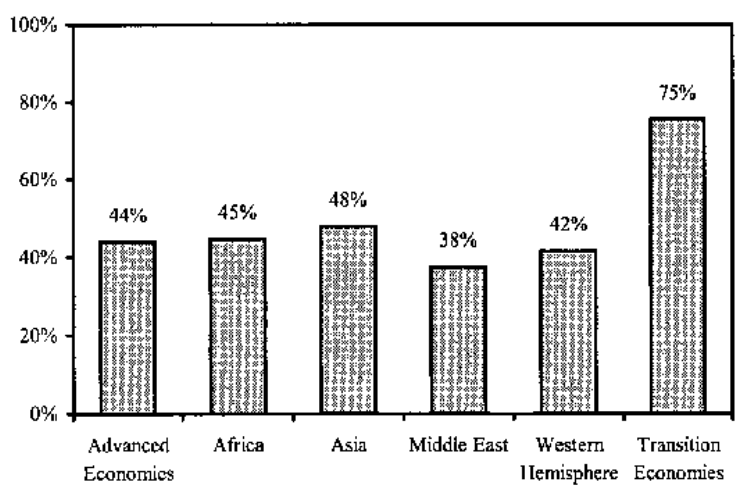

Source: IMF Survey on the Use, Compilation, and Dissemination of Macroprudential Indicators. 
Figure 16. Percentage of Respondents Disseminating Data Collected on Individual Indicators

Advanced Economies

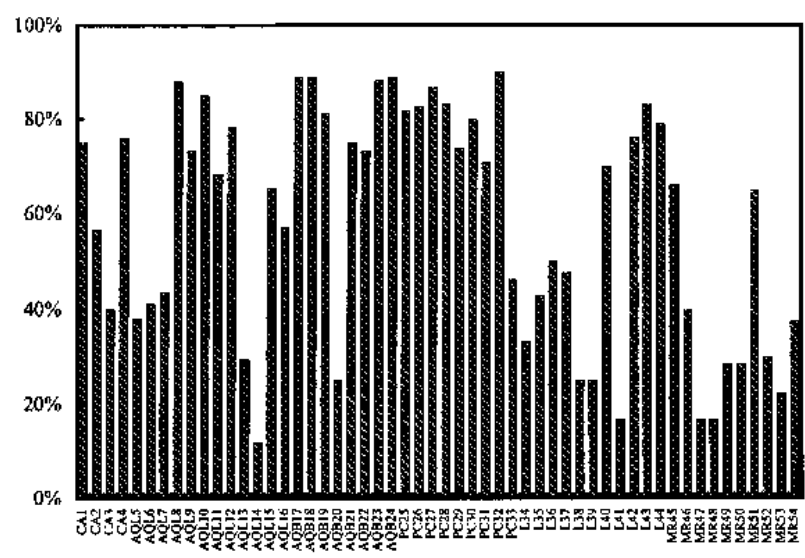

Asia

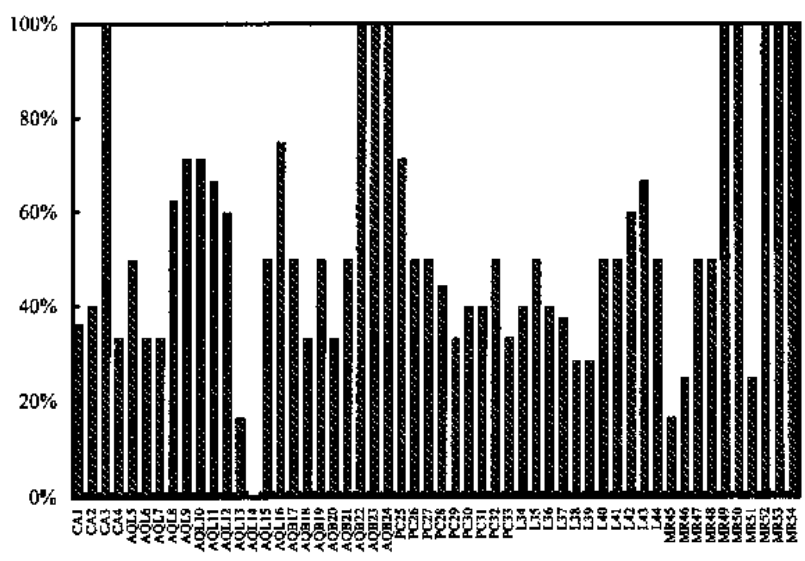

Western Hemisphere

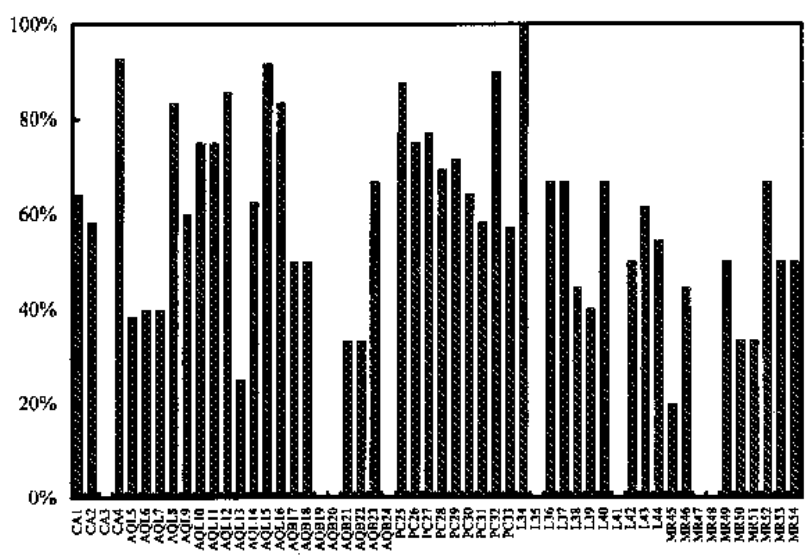

Africa

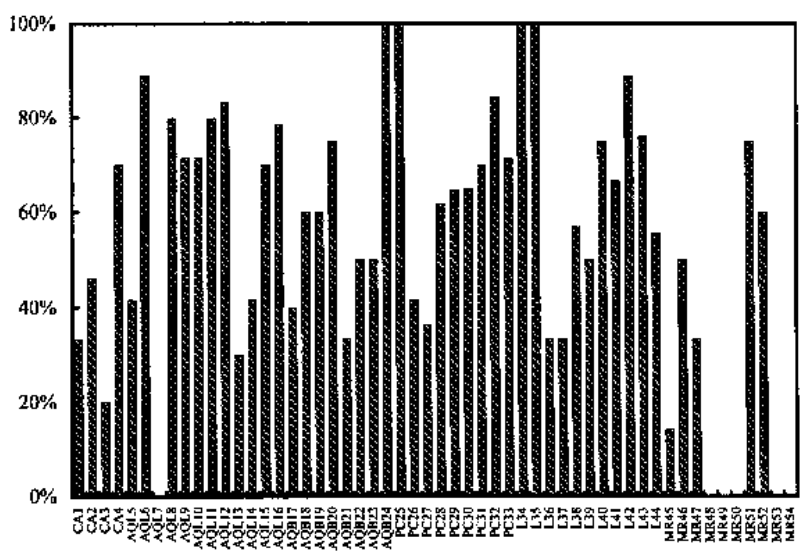

Middle East

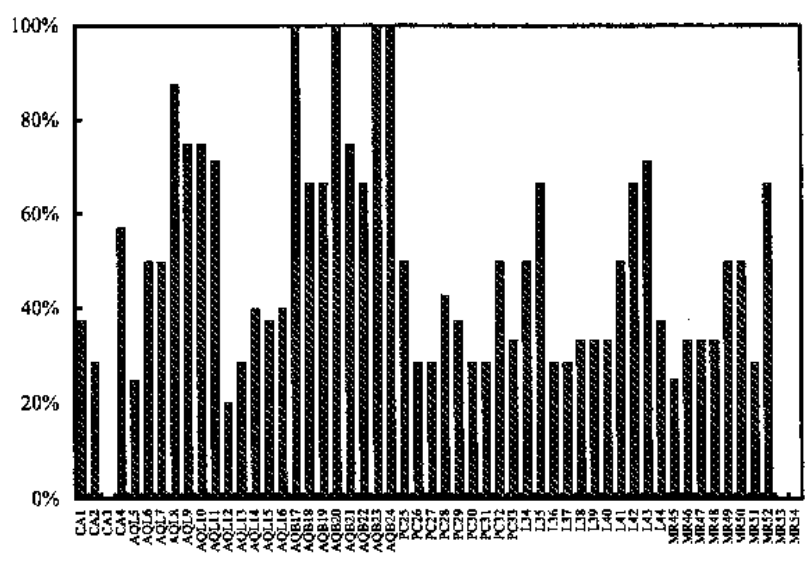

Transition Economies

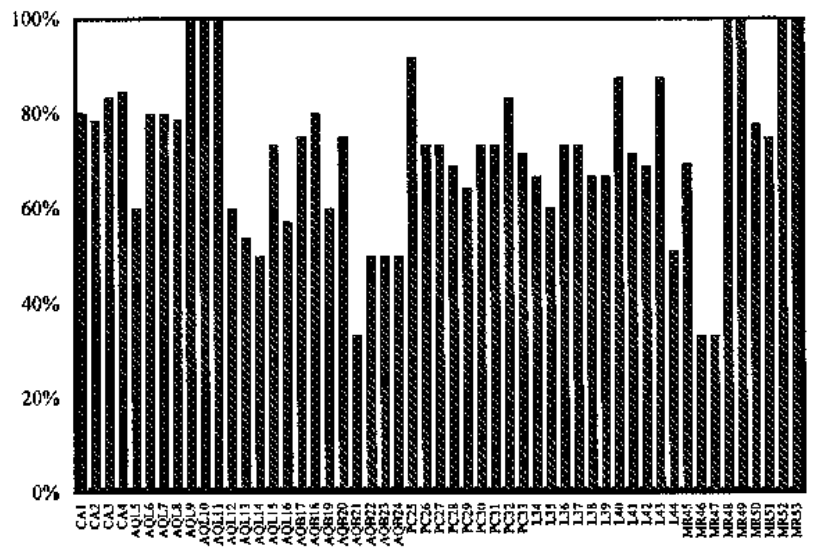

Source: IMF Survey on the Use, Compilation, and Dissemination of Macroprudential Indicators.

Note: The following short hand abbreviations are used to identify FSI categories: $\mathrm{CA}=$ Capital Adequacy; $\mathrm{AQL}=\mathrm{Asset}$ Quality (lending institution); $\mathrm{AQB}=$ Asset Quality (borrowing institution); $\mathrm{PC}=$ Profitability and Competitiveness; $\mathrm{L}=$ Liquidity; and MR = Market Risk. Indicators in each FSI category are identified by number. For example, MR2 refers to the second market risk indicator listed in Appendix II. 
Respondents are typically least eager to disseminate data collected on credit to related entities and on large loans to own funds -30 percent of respondents disseminate data collected on these indicators. None of the respondents in Asia disseminate data collected on large loans to own funds. And, whereas almost all respondents in Africa disseminate data collected on total gross asset position in financial derivatives, none disseminate data collected on the total liability position in financial derivatives.

\section{Asset quality (borrowing institution)}

Respondents in advanced economies and the Middle East are most eager to disseminate data they collect on indicators of asset quality (borrowing institution). Western Hemisphere countries are the least eager to disseminate, providing only one-third of their collected data to the public. For all but one indicator (household debt owed to banks), half or more of the Western Hemisphere respondents that collect data on indicators in this FSI category do not disseminate.

Respondents are typically most eager to disseminate data on corporate debt to own funds, corporate profit to equity, household debt owed to other depository corporations, ${ }^{22}$ and the number of applications for protection from creditors -80 percent of respondents disseminate data collected on these indicators. Conversely, respondents are typically least eager to disseminate data collected on corporate net foreign currency exposure and on total household debt to GDP-between 50 and 60 percent of respondents disseminate data collected on these indicators. None of the Western Hemisphere respondents and only 30 percent of advanced and Asian respondents disseminate data collected on corporate net foreign currency exposure. By contrast, all Middle Eastern respondents and 80 percent of African and transition respondents disseminate data collected on this indicator.

\section{Profitability and competitiveness}

While advanced economies are most eager to disseminate the data they collect on indicators in this FSI category, transition, Western Hemisphere, and African economies also show a strong eagerness to disseminate. This is especially so relative to respondents in Asia and the Middle East, which disseminate only 46 and 36 percent respectively of the data they collect.

Respondents are typically most eager to disseminate data collected on the rate of change in the number of depository corporations and the spread between the reference lending and deposit rates -80 percent of respondents disseminate data collected on these indicators. Nevertheless, more than half of the African and Middle Eastern respondents do not

\footnotetext{
22 This is a national accounts (SNA93) concept and includes banks (except the central bank) and other financial corporations whose principal activity is financial intermediation and which have liabilities in the form of deposits or financial instruments which are close substitutes for deposits.
} 
disseminate data collected on the ratio of profits to assets and to equity. And two thirds of Asian respondents do not disseminate data collected on trading and foreign exchange gains/losses to profits.

\section{Liquidity indicators}

Transition countries are most eager to disseminate data collected on indicators in this FSI category, followed by African, advanced, and Western Hemisphere countries. Respondents in the Middle East and Asia again lag behind, disseminating less than half the data they collect on indicators of liquidity.

Respondents are typically most eager to disseminate data collected on customer deposits to total noninterbank loans -80 percent of respondents disseminate data collected on this indicator. There is also a general eagerness to disseminate data collected on central bank credit to banks and on turnover in the T-bill market -70 percent of respondents disseminate data collected on this indicator. However, only 30 and 50 percent of Middle Eastern and Asian countries, respectively, disseminate data collected on turnover in the T-bill market.

While only 40 percent of respondents disseminate data collected on the average maturity of assets and liabilities, 70 percent of transition and up to 60 percent of African country respondents disseminate data collected on these indicators. Notable differences in country practices are also apparent for the dissemination of data collected on liquid assets and liquid liabilities. Whereas 70 percent of Western Hemisphere and transition country respondents disseminate data collected on these indicators, 30 percent of African and Middle Eastern respondents, 40 percent of Asian respondents, and 50 percent of respondents in advanced economies disseminate data collected on these indicators. Asian, Middle Eastern, and Western Hemisphere respondents are also typically less eager than other respondents to disseminate data collected on customer foreign currency deposits to total (noninterbank) foreign currency loans.

\section{Sensitivity to market risk}

Respondents in transition economies are typically much more eager than other respondents to disseminate data collected on FSIs in this category. Nevertheless, for all but one of the indicators (gross equity position to own funds), half or less of all respondents disseminate the data they collect. Respondents are typically least eager to disseminate data collected on foreign currency assets to own funds, and on average interest rate repricing-between 20 and 30 percent of respondents disseminate data collected on these indicators. An exception is that 50 and 70 percent of transition and advanced countries, respectively, disseminate data collected on foreign currency assets to own funds. Also, whereas typically half of the respondents disseminate data collected on net foreign currency position to own funds, 30 percent of Asian and Middle Eastern respondents and 70 percent of respondents with transition economies disseminate data collected on this indicator. 


\section{Crisis countries}

Crisis countries are typically more eager than noncrisis countries to disseminate 36 of the surveyed indicators, and less eager than noncrisis countries to disseminate 17 indicators. In particular, they are typically least eager to disseminate indicators of duration, corporate net foreign currency exposure, distribution of capital adequacy ratios, and positions in financial derivatives, but naturally there are differences across country groups. The salient points for each country group are highlighted in the remainder of this section.

Figure 17 shows the eagerness of crisis and noncrisis countries in each country group to disseminate. It suggests that crisis countries in Africa, Asia, and the Western Hemisphere are typically much more eager to disseminate collected data than their noncrisis counterparts. Furthermore, Figures 18 and 19 show that this heightened eagerness extends across almost all categories of FSI and across most individual indicators, which may suggest an awareness of the benefits of disclosure among counties that have experienced crises.

Figure 17. Percentage of Collected Data on FSIs Disseminated, Disaggregated by Crisis and Noncrisis Countries

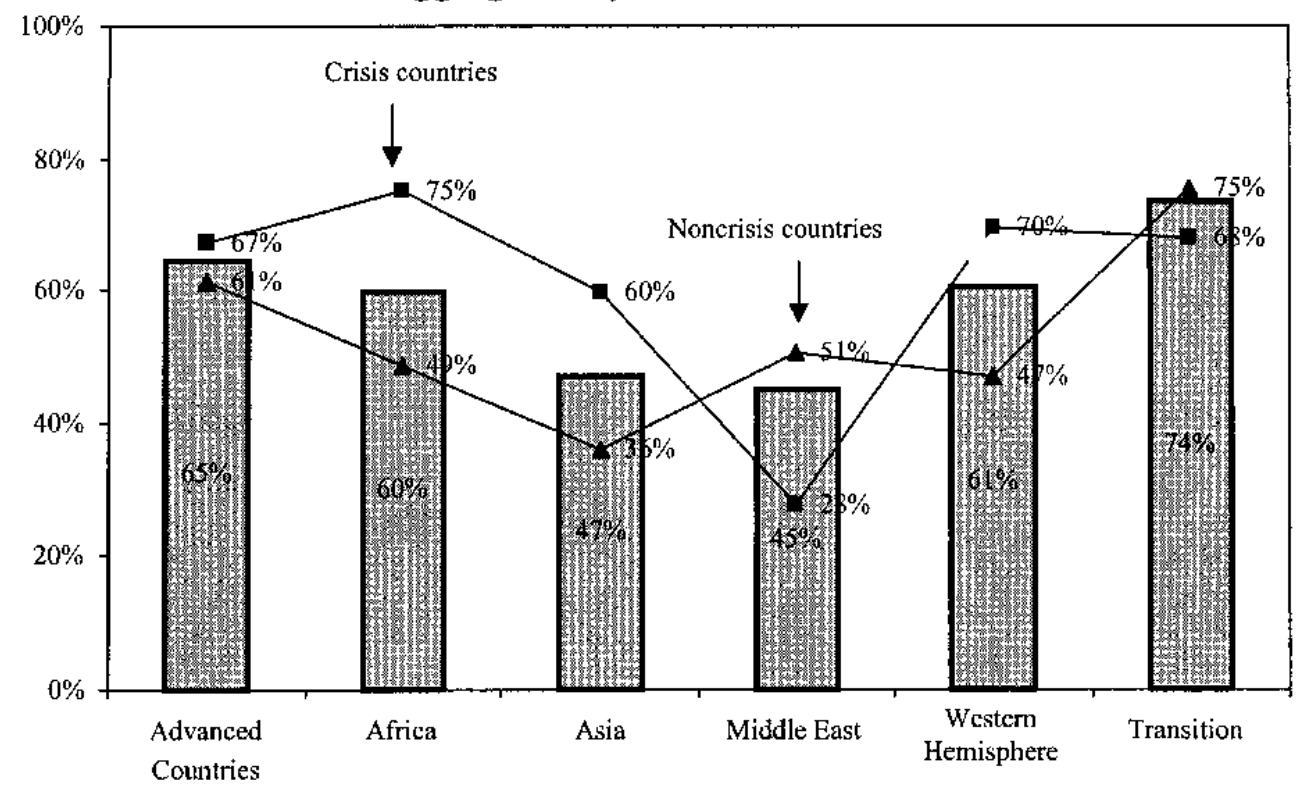

By contrast, Middle Eastern economies that have experienced crisis tend to disseminate a lower proportion of the data they collect than their noncrisis counterparts across all FSI categories. Transition economies that have experienced crisis also tend to be less eager to disseminate collected data than their noncrisis counterparts, especially in the FSI categories of asset quality. 
Figure 18. Proportion of Indicators on Which Data Are Collected and Disseminated:

Crisis and Noncrisis Countries

Advanced Economies

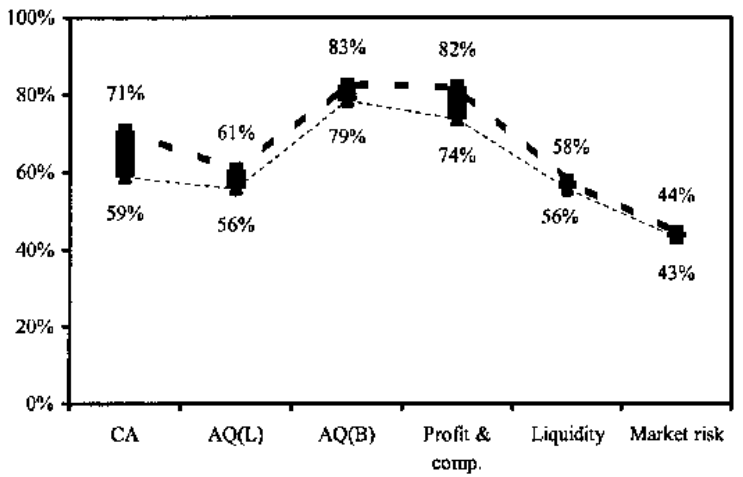

Asia

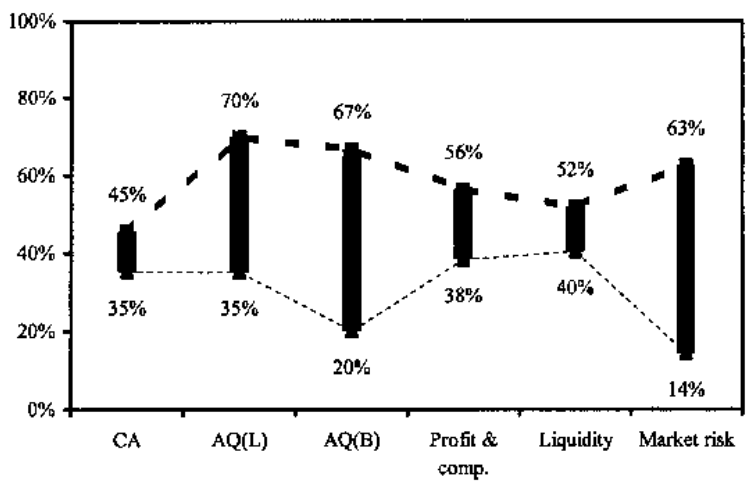

Western Hemisphere

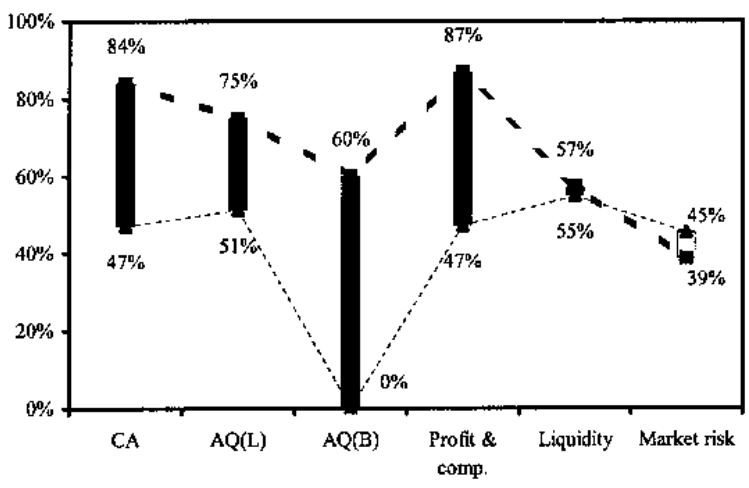

Africa

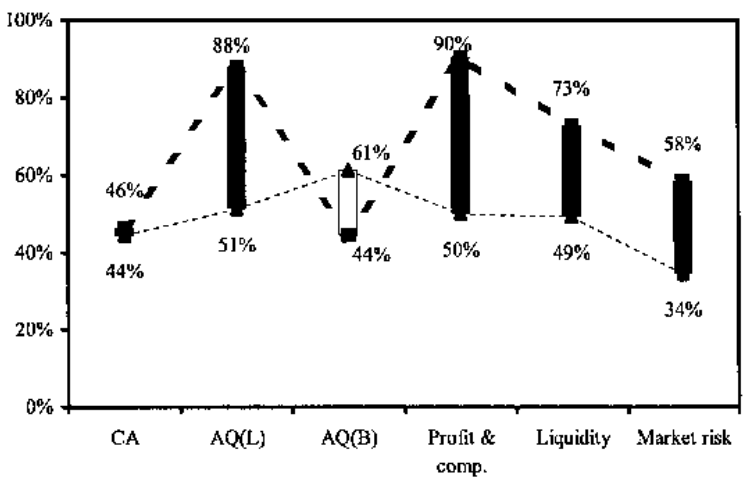

Middle East

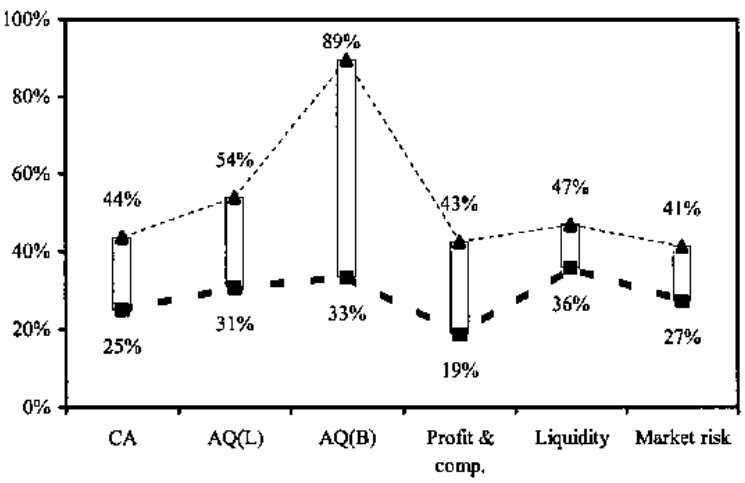

Transition Economies

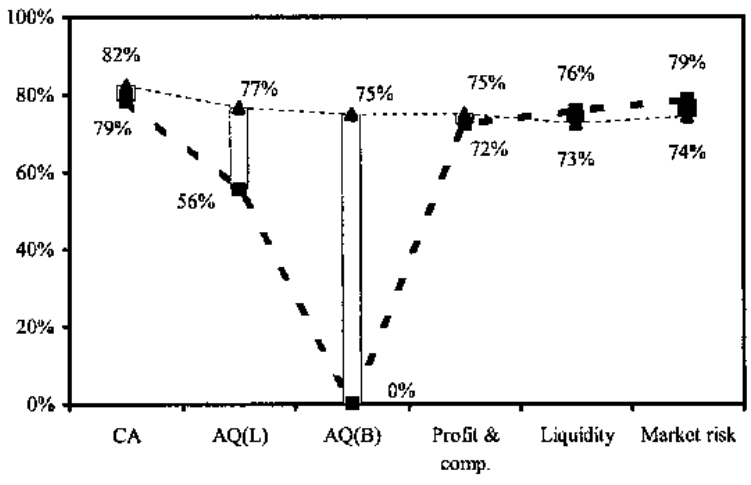

Source: IMF Survey on the Use, Compilation, and Dissemination of Macroprudential Indicators.

Notc: The following short hand abbreviations are used to identify FSI categories: $\mathrm{CA}=$ Capital Adequacy; $\mathrm{AQ}(\mathrm{L})=$ Asset Quality (lending institution); $\mathrm{AQ}(\mathrm{B})=$ Asset Quality (borrowing institution); and Profit. and comp. $=$ Profitability and Competitiveness. 
Figure 19. Differences in the Eagerness of Crisis and Noncrisis Countries to Disseminate Data Collected on Individual Indicators

Advanced Economies

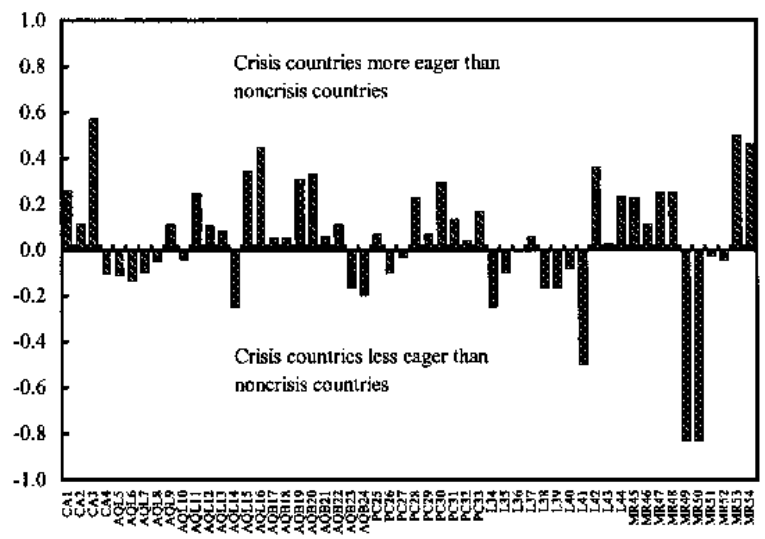

Asia

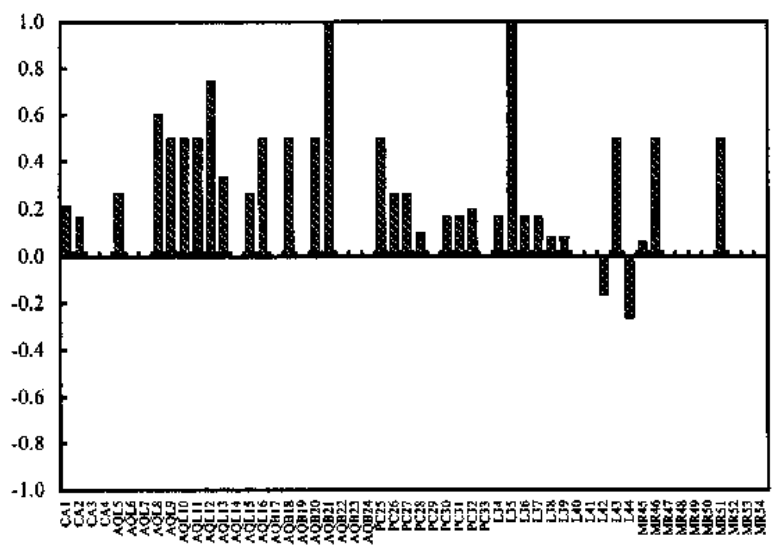

Western Hemisphere

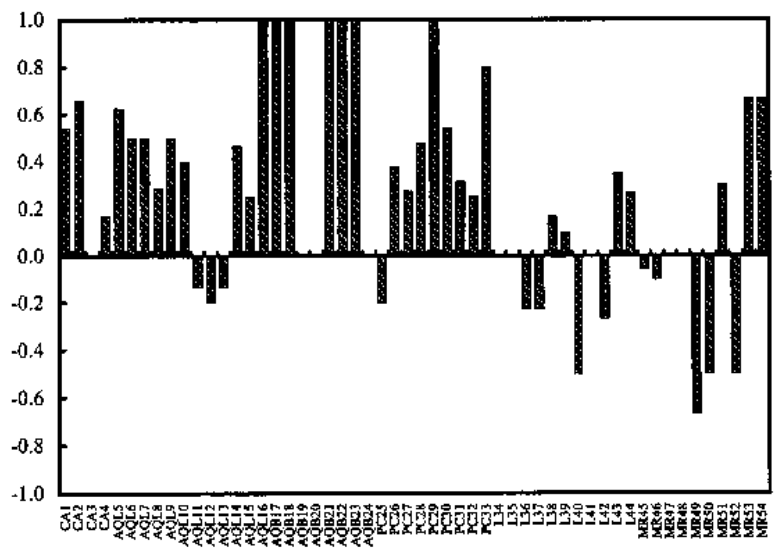

Africa

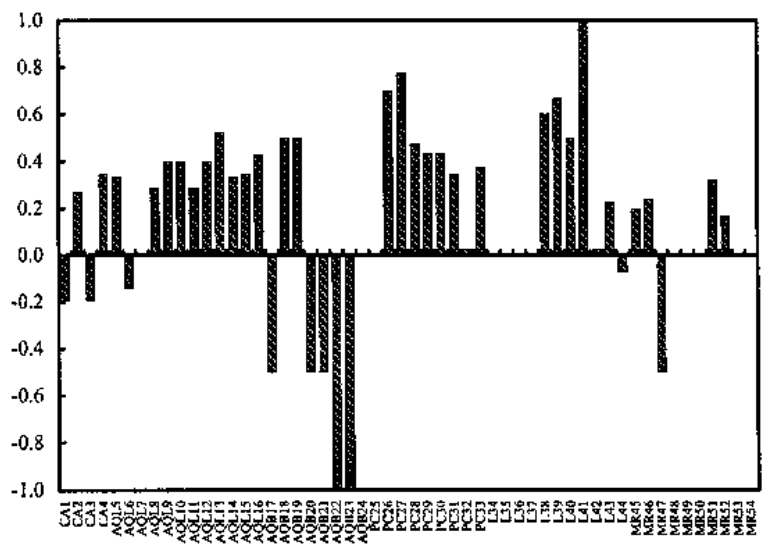

Middle East

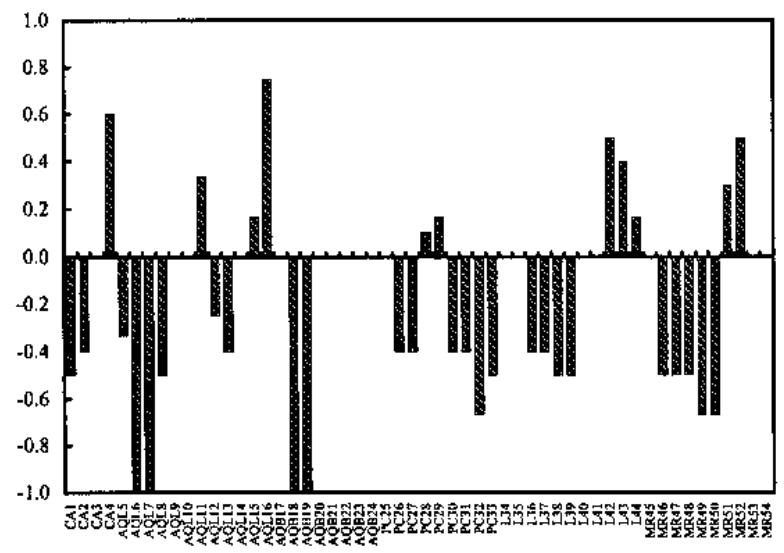

Transition Economies

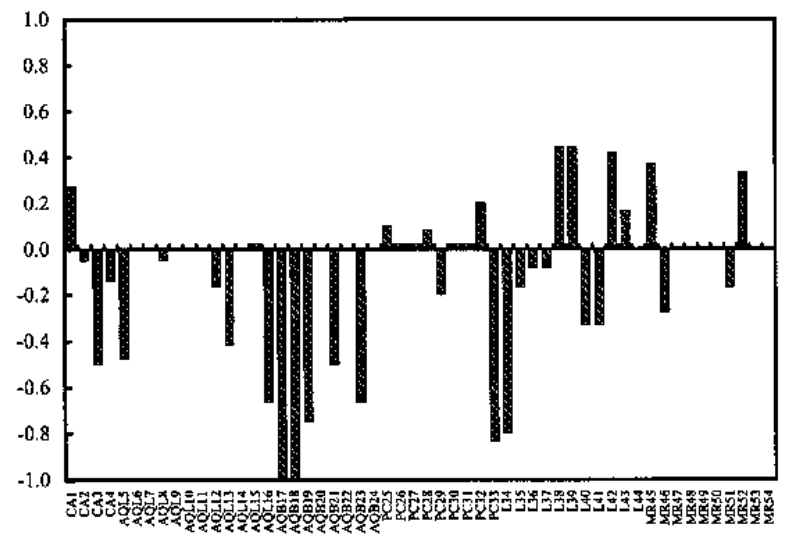

Source: IMF Survey on the Use, Compilation, and Dissemination of Macroprudential Indicators.

Note: The following short hand abbreviations are used to identify FSI categories: $\mathrm{CA}=$ Capital Adequacy; $\mathrm{AQL}=\mathrm{Asset}$ Quality (lending institution); $\mathrm{AQB}=$ Asset Quality (borrowing institution); $\mathrm{PC}=$ Profitability and Competitiveness; $\mathrm{L}=$ Liquidity; and MR = Market Risk. Indicators in each FSI category are identified by numbcr. For example, MR2 refers to the second market risk indicator listed in Appendix II. 


\section{Advanced countries}

Crisis countries with advanced economies are at least as eager to disseminate data as their noncrisis counterparts across all FSI categories (see Figure 18). By individual indicator, they are less eager to disseminate data on the following: the leverage ratio, five asset quality (lending institution) indicators, (notably large loans to own funds), household debt owed to depository corporations as a percentage of GDP, number of applications for protection from creditors, return on assets, six liquidity indicators (notably distribution of local-currency interbank rates, average maturity of assets and liabilities, and bid-ask spreads in the T-bill market), and duration of assets and liabilities (see Figure 19).

\section{African countries}

African crisis countries disseminate proportionately more data on indicators in all FSI categories, except for asset quality (borrowing institution). For this category, African crisis countries are more eager than noncrisis countries to disseminate data on only 2 indicators (corporate profits to equity and corporate debt service costs to total corporate income).

African crisis countries are less eager than noncrisis countries to disseminate data collected on the following indicators: capital adequacy ratios and their distribution, gross asset position in financial derivatives, corporate debt to own funds, corporate net foreign currency exposure, household debt to GDP and related breakdowns, customer foreign currency deposits to total noninterbank foreign currency loans, and average interest rate repricing period for assets.

\section{Asian countries}

Asian crisis countries are more eager than their noncrisis counterparts to disseminate data on 31 indicators and less eager to disseminate data on only 2 indicators-namely, central bank credit and customer foreign currency deposits to total foreign currency loans, in the category of liquidity. This additional eagerness to disseminate data is evident across all FSI categories.

\section{Western Hemisphere countries}

Western Hemisphere crisis countries disseminate proportionately more of their data than noncrisis countries on indicators in all FSI categories, except for market risk. Western Hemisphere crisis countries are more eager than their noncrisis counterparts to disseminate data on 32 indicators, and less eager to disseminate data on 13 indicators.

Western Hemisphere crisis countries are less eager than noncrisis countries to disseminate data on the following indicators: distribution of credit by sector, country or region, and credit to related entities, rate of change in the number of banks, liquid assets to total assets, liquid assets to liquid liabilities, turnover in the T-bill market, and central bank credit to banks, and five liquidity indicators (notably duration of assets and liabilities, and net equity position to own funds). 


\section{Middle Eastern countries}

Countries in the Middle East that have not experienced a banking crisis disseminate data on about twice as many of the indicators for which they collect data than crisis countries in the region. Only one third of the indicators that are available to policymakers in Middle Eastern crisis countries are disseminated to the public. The tendency for crisis countries to disseminate a much narrower range of collected data than noncrisis countries is evident across all FSI categories, but especially in the category of asset quality (borrowing institution) (see Figure 18).

Crisis countries are less eager than noncrisis countries to disseminate data collected on 25 indicators (see Figure 19). None of the crisis countries disseminate data collected on indicators relating to financial derivatives, corporate profits to equity, or corporate debt service costs to total corporate income, whereas all noncrisis countries disseminate data collected on these indicators. Also, none of the crisis countries disseminate data collected on a further 18 indicators, including capital adequacy and credit to related entities.

Against this general reluctance to disseminate, Middle Eastern crisis countries are more eager than noncrisis countries to disseminate data collected on the following indicators: the leverage ratio, distribution of credit by sector, nonperforming loans to assets, nonperforming loans net of provisions to total assets, net interest income to profits, trading and foreign exchange gains and losses to profits, central bank credit, customer deposits to total noninterbank loans, customer foreign currency deposits to total noninterbank foreign currency loans, and gross and net equity positions to own funds.

\section{Transition countries}

Crisis countries with transition economies disseminate proportionately less of their data than noncrisis countries on indicators of asset quality (lending institution) and asset quality (borrowing institution). Crisis countries show about the same eagerness as noncrisis countries to disseminate data collected on indicators in other FSI categories. For the FSI category of asset quality (borrowing institution), crisis countries disseminate none of the data they collect, whereas noncrisis countries disseminated three-quarters of the data they collect. Crisis countries also appear to be especially reluctant to disseminate data on nonperforming loans net of provisions in the category of asset quality (lending institution).

Crisis countries are more eager than noncrisis countries to disseminate data collected on the following indicators: capital adequacy ratio, rate of change in the number of depository corporations, net interest income to profits, and spread between reference deposit and lending rates, average maturity of assets and liabilities, central bank credit, and customer deposits to total noninterbank loans, gross foreign currency assets to own funds, and gross equity position to own funds. 
The variation in eagerness to disseminate data on FSIs-both across FSI categories and country groups-may reflect authorities' concern about the reliability of some newly collected data series, a lack of sufficient time series to enable proper interpretation of the data, ${ }^{23}$ and concern about market reaction to the information encapsulated in the FSIs. Nevertheless, the gaps between data collection and data dissemination suggest there is potential for providing increased information to the public at little additional cost to the data collecting and compiling agencies. In addition, differences between crisis and noncrisis countries in their eagerness to disseminate suggests crises experience may encourage enhanced disclosure and transparency in some regions.

\section{CoRe AND ENCOURAgEd Financial Soundness Indicators}

Using the results of the survey as a guide, the IMF's Executive Board endorsed in June 2001 a set of core and encouraged FSIs. Ongoing work at the IMF has focused on this set of FSIs to prepare definitional guidelines to facilitate compilation and convergence toward best practice (see Sundararajan and others (2002)). Further down the road, member countries would be encouraged to compile and disseminate all the core FSIs and to compile the encouraged indicators depending on country circumstances. As a first step, a natural question is how close are countries already to collecting and disseminating data on these core and encouraged indicators. Table 3 provides information on the proportion of survey respondents collecting and disseminating data on the core and encouraged indicators specified in the survey.

\section{A. Core Indicators}

Eighty percent or more of the survey respondents collect data on 10 of the 15 core indicators included in the survey. Less widespread is the collection of data on large loans to own funds, nonperforming loans net of provisions to total assets, and net foreign currency position to own funds. Only 20 percent of respondents collect data on duration of assets and liabilities, suggesting a need for additional data collection effort by a significant number of countries in this area. For all the core indicators, there is room for more countries to disseminate to the public data that are already collected. For instance, for all but one indicator (distribution of loans by sector), fewer than three quarters of the respondents disseminate collected data (either as ratios or as data series). And only half of the respondents disseminate data collected on core indicators of capital adequacy, liquidity, and market risk.

\footnotetext{
${ }^{23}$ Because trends in FSIs can be cyclical, time series data for at least one business cycle provide a useful reference point for interpreting the current level of FSI ratios.
} 
Table 3. Core and Encouraged Financial Soundness Indicators 1/

Collecting Disseminating Eagerness

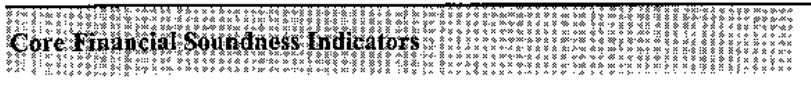

Capital Adequacy

1. Capital Adequacy Ratio

2. Basel Tier I Capital to risk-wcighted assets

0.8

Asset Quality (Lending Institution)

8. Distribution of luans, by sectot

14. Ratio of total large loans to own funds

15. Ratio of gross nonperforming loans to total assets

16. Ratio of nonperforming loans net of provisions to tertal assets

Profitability and Competitiveness

26. Ratio of profits to period-average assets (ROA)

27. Ratio of profits to period-average equity (ROE)

28. Ratio of net isterest incomes to profits

30. Rativ of aperatifig costs to net interest incoune

Liquidity Indiestors

36. Ratio of liquid assets to total assets

37. Ratio of liquid assets to liquid liabilitics

Sensitivity to Market Risk

46. Ratio of net foreign currency position to own funds

49. Duration of assets

50. Duration of liabilitics

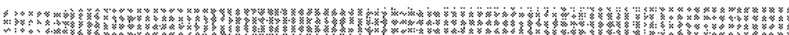

Encouraged Fingendu sound ness fridicators

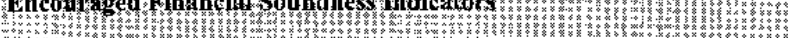

Deposit Taking lnstitutions

4. Leverage Ratio

6. Ratio of total gross asset position in financial derivatives to profits

7. Ratio of total gross liability position in financial derivatives to own funds

12. Distribution of credit extended, by country or region

29. Ratio of trading and foreign cxchange gainsilosses to profits

31. Ratio of staff costs to opcrating costs

32. Spread between reference lending and deposit ratcs

35. Average interbank bid-ask spread for 3-month local-currency depusils

43. Ratio of customer deposits to total (noninterhank) loans

52. Ratio of net cequity position to own funds

Market Liquídity

40. Average daily tumover in the T-bill (or central bank bill) market

41. Average bid-ask spread in the T-bill (or central bank bill) natrket

Corporate Secter

17. Ratio of corporate debt to nwh funds ("debt-equity ratio")

18. Ratio of corporate profits to equity

19. Ratio of corporate dicbt scrvice costs 10 total corporate income

20. Corporate net foreign currency exposure

24. Number of applications for protection from creditors

Houscholds

21. Ratio of houschold total debt to GDP

0.2

0.6

Real Estate Markets

9. Loans for investment in commcrcial rcal estate

10. Loans for investment in residential real cstatc

$0.4 \quad 0.3$

0.4

0.7

Source: MFF Survey on the Use, Collection, and Dissemination of Wacroprudential Indicators.

1/ The proportion of respondents collecting data series is shown. Ali numbers rounded to the nearest 0.1 . 
The additional data dissemination effort implied by the above results is not evenly distributed across country groups, as shown in Figure 20. In particular, African, Asian, and Middle Eastern respondents are significantly less eager to disseminate available data on capital adequacy and profitability and competitiveness indicators than the other country groups. By contrast, respondents in the Western Hemisphere and those with transition economies tend to be most active in disseminating collected data (Appendix III provides eagerness ratios by country group). On the data collection side, Figure 20 also suggests that proportionately fewer countries in Asia and Africa currently collect data on the core indicators. Nevertheless, on a de minimus basis, Figure 21 shows that at least 85 percent of the respondents collect at least one core indicator in each of the FSI categories, except for market risk, for which about 60 percent of respondents collect data on at least one of the core indicators.

\section{B. Encouraged Indicators ${ }^{24}$}

There is more widespread paucity of data for the encouraged than for the core set of indicators, particularly outside the advanced economies. Data on indicators for the corporate and household sectors and real estate markets are particularly scarce (Figure 22). As shown in Figure 23, a significant number of respondents collect data on none of the encouraged indicators for these sectors. Moreover, less than half of the respondents in each country group collect data on interbank bid-ask spreads for 3-month local currency deposits, net equity position to own funds, average bid-ask spread in the T-bill (or central bank market), corporate net foreign currency exposure, and the number of applications for protection from creditors.

As with the core indicators, there is room for countries to increase their public dissemination of collected data, particularly in Asia and the Middle East but also in the advanced economies and in the Western Hemisphere. Respondents in Africa and with transition economies especially are relatively more eager than others to disseminate available data on the encouraged indicators (Appendix III provides the eagerness ratios by country group).

\footnotetext{
${ }^{24}$ Twenty of the twenty six encouraged indicators approved by the IMF Board were included in the IMF Survey.
} 
Figure 20. Proportion of Countries Collecting and Disseminating Data on Core FSIs

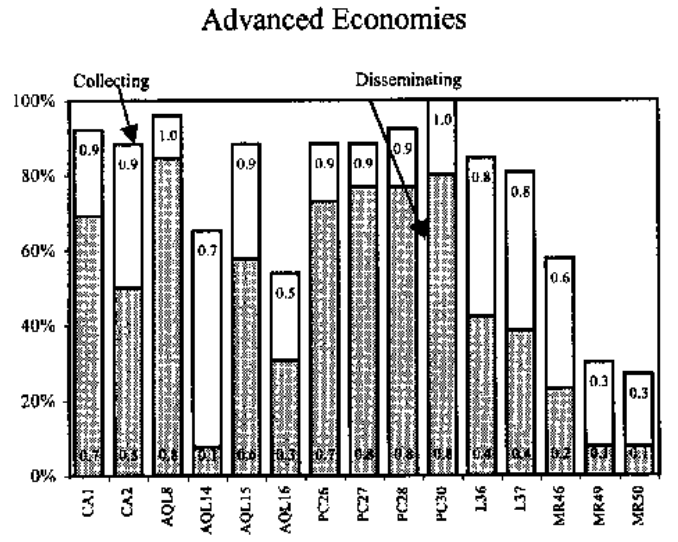

Asia

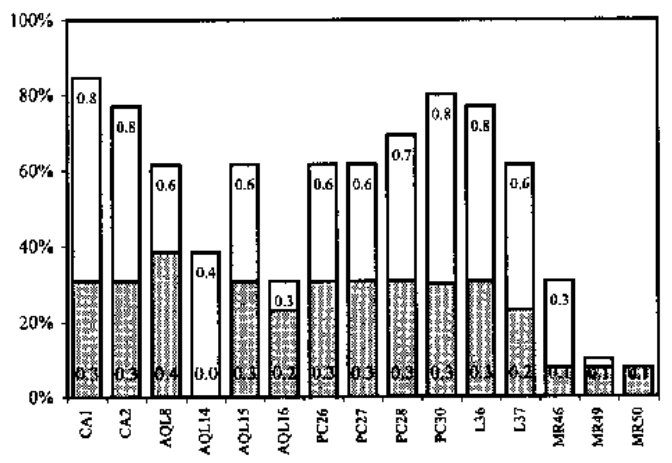

Western Hemisphere

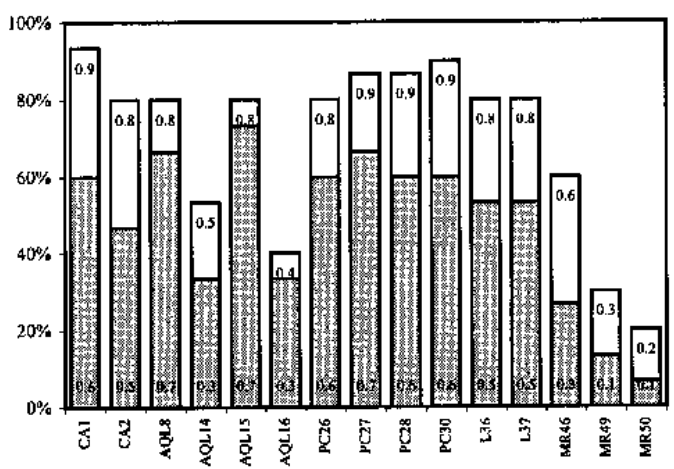

Africa

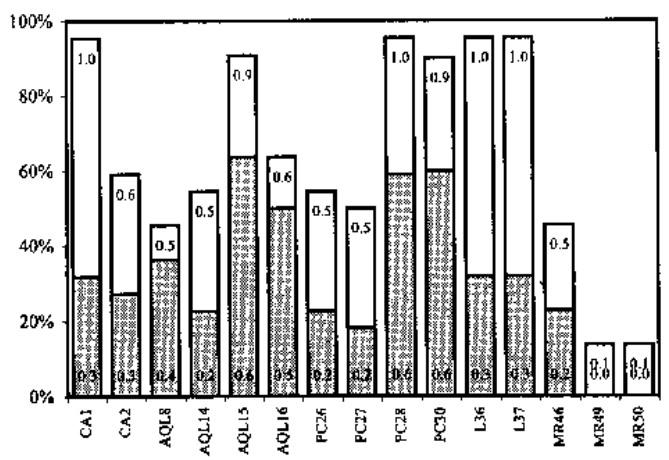

Middle East

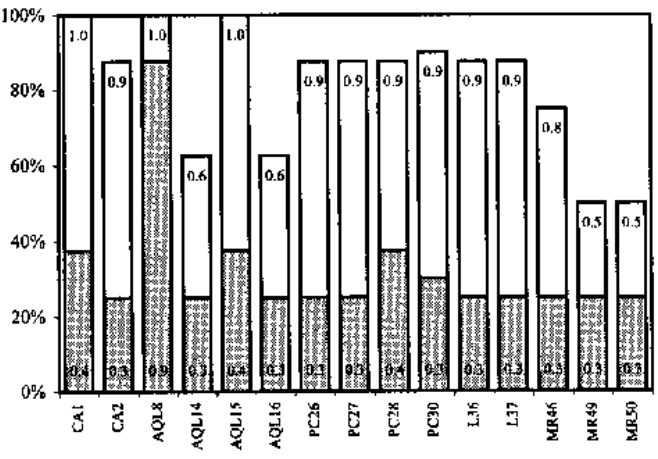

Transition Economies

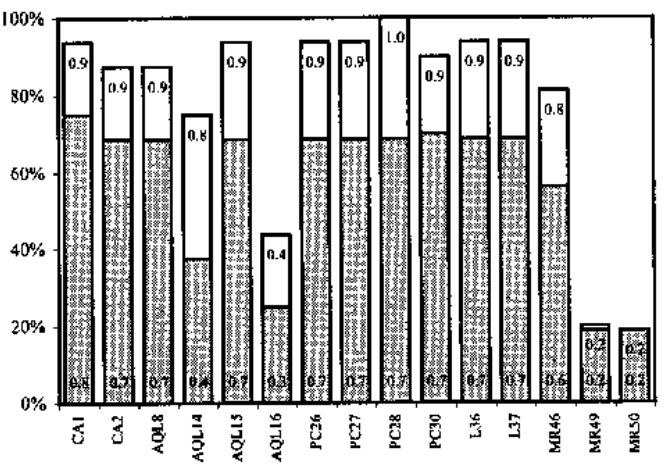

Source: IMF Survey on the Use, Compilation, and Dissemination of Macroprudential Indicators

Note: The following short hand abbreviations are used to identify core FSI categories: $\mathrm{CA}=$ Capital Adequacy; $\mathrm{AQL}=$ Asset Quality (lending institution); PC = Profitability and Competitiveness; $\mathrm{L}=$ Liquidity; and MR = Market Risk. Indicators in each core FSI category are identified by number. For example, CA2 refers to the second core capital adequacy indicator listed in Table 3. 
Figure 21. Distribution of Number of Countries Collecting Data on Core FSIs

Capital Adequacy

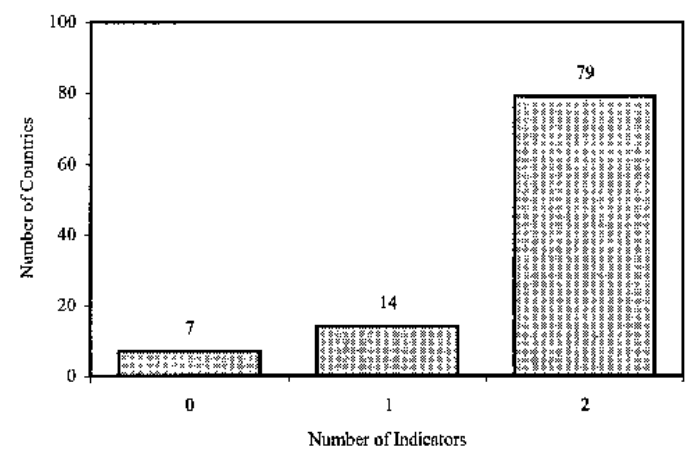

Profitability and Competitiveness

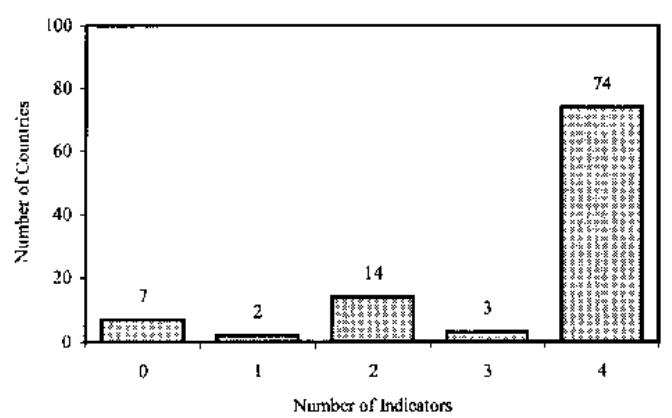

Market Risk

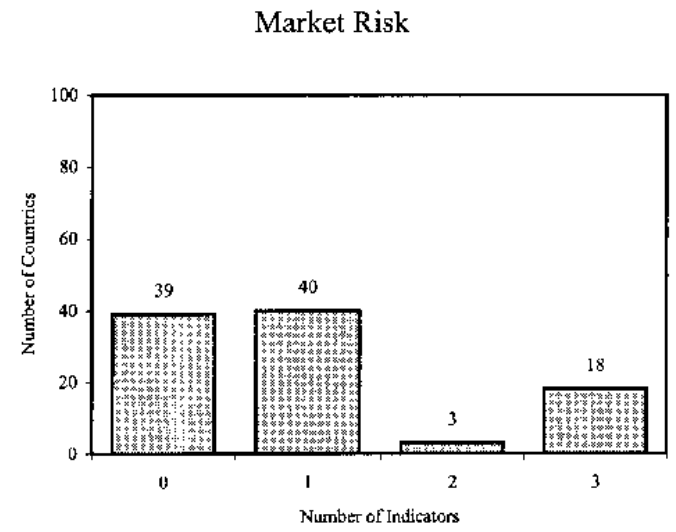

Asset Quality (lending institution)

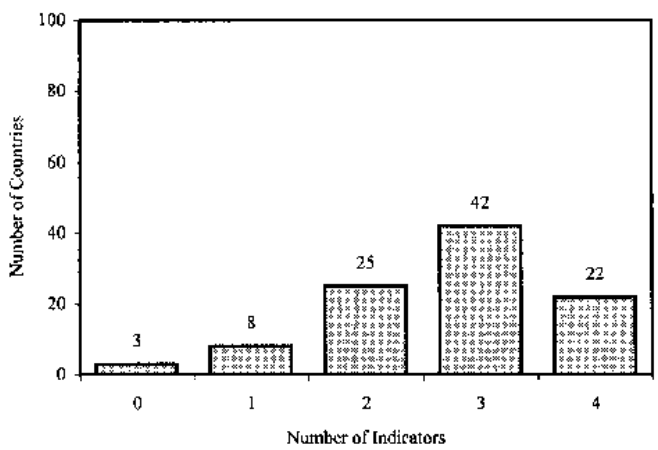

Liquidity

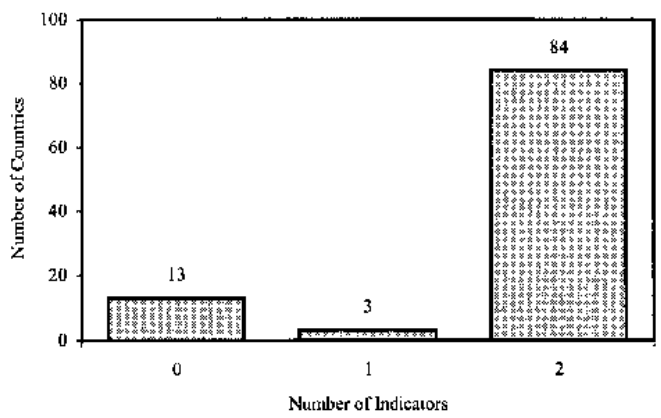

Source: IMF Survey on the Use, Compilation, and Dissemination of Macroprudential Indicators. 
Figure 22. Proportion of Countries Collecting and Disseminating Data on Encouraged FSIs

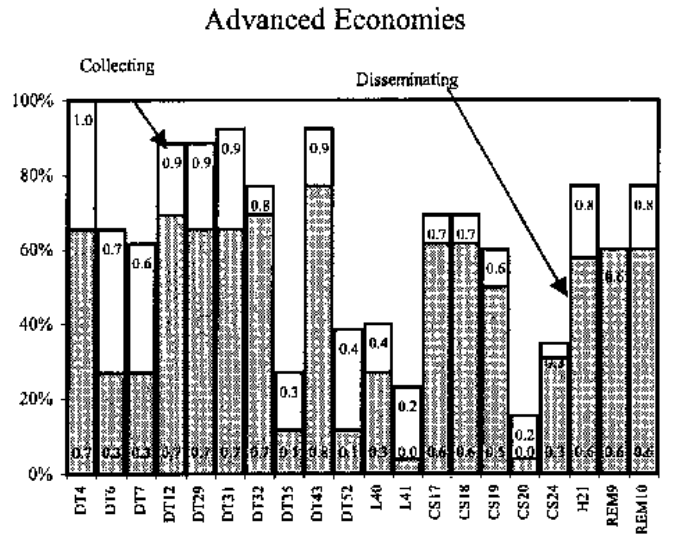

Asia

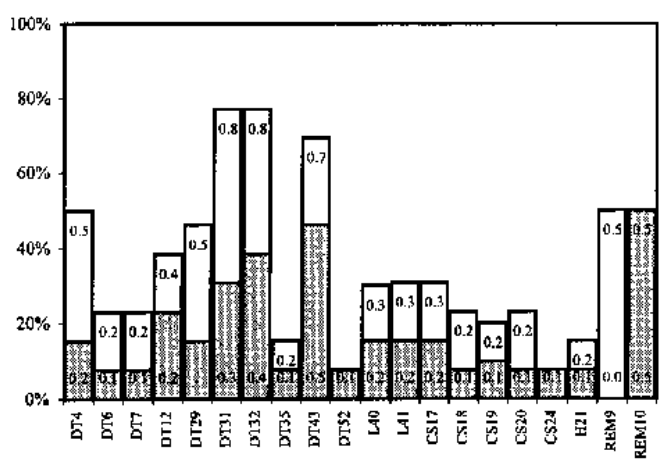

Western Hemisphere

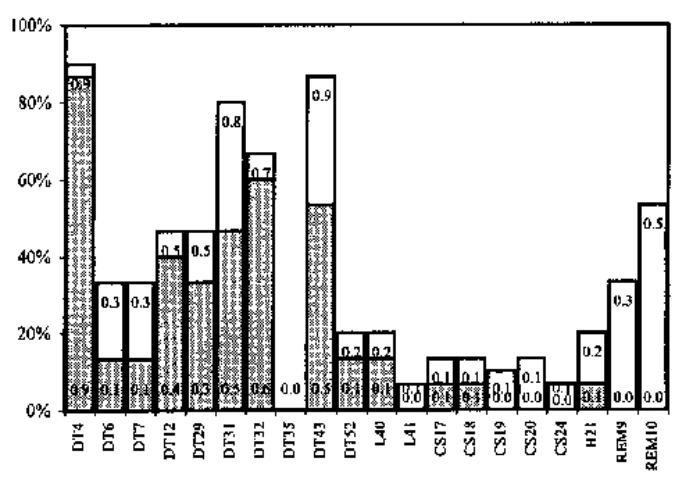

Africa

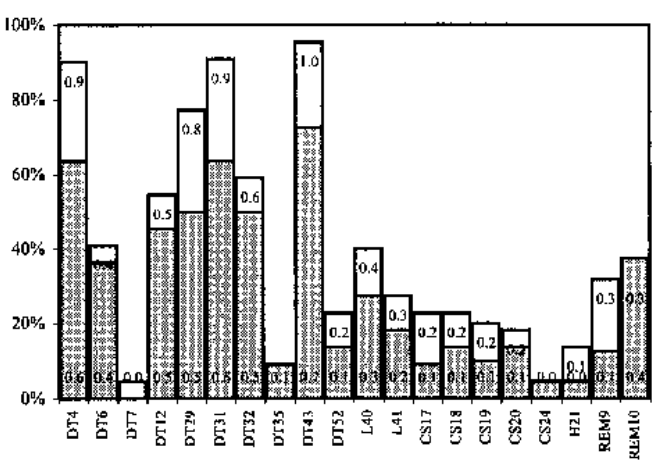

Middle East

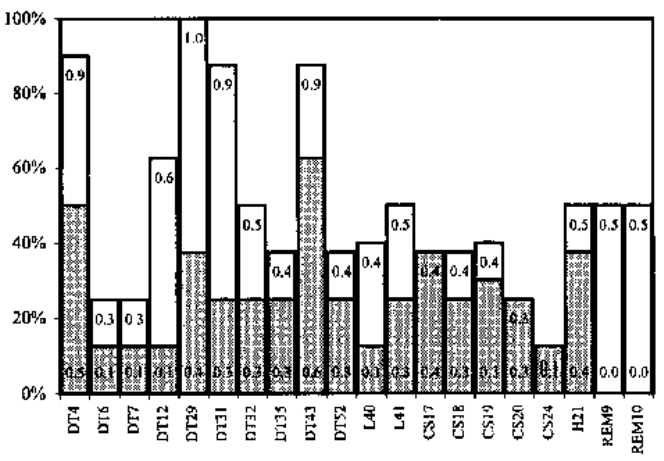

Transition Economies

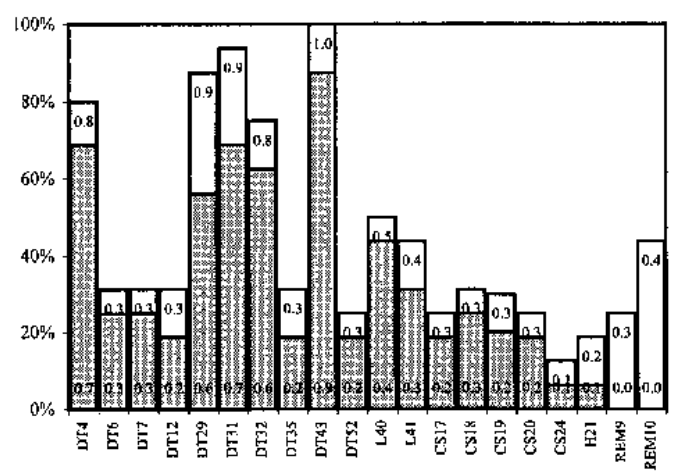

Source: IMF Survey on the Use, Compilation, and Dissemination of Macroprudential Indicators.

Note: The following short hand abbreviations are used to identify cncouraged FSI categories: DT = Deposit Taking Institutions; $\mathrm{L}=$ Liquidity; $\mathrm{CS}$ = Corporate Sector; $\mathrm{H}=$ Households; and REM = Real Estate Market. Indicators in each encouraged FSI category are identified by number. For example, DT4 refers to the fourth encouraged indicator on deposit taking institutions listed in Table 3. 
Figure 23. Distribution of Number of Countries Collecting Data on Encouraged FSIs

Deposit Taking Institutions

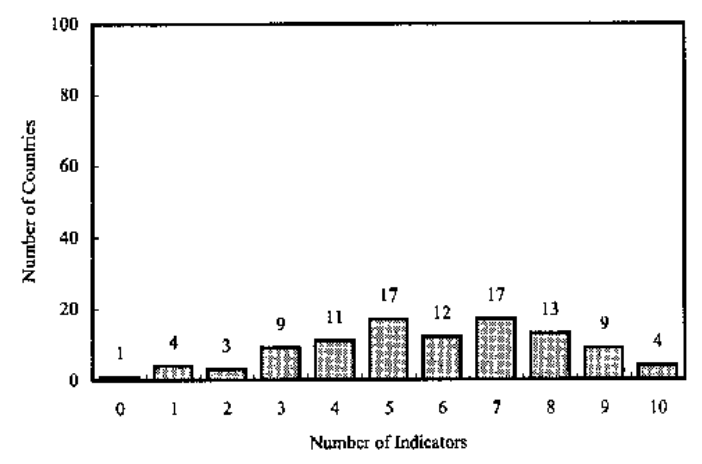

Corporate Sector

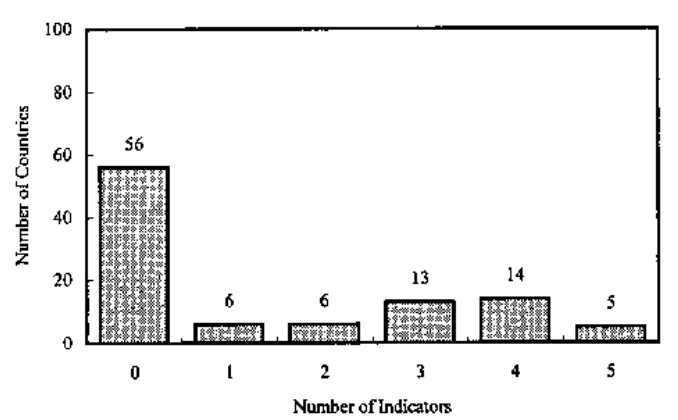

Real Estate Market

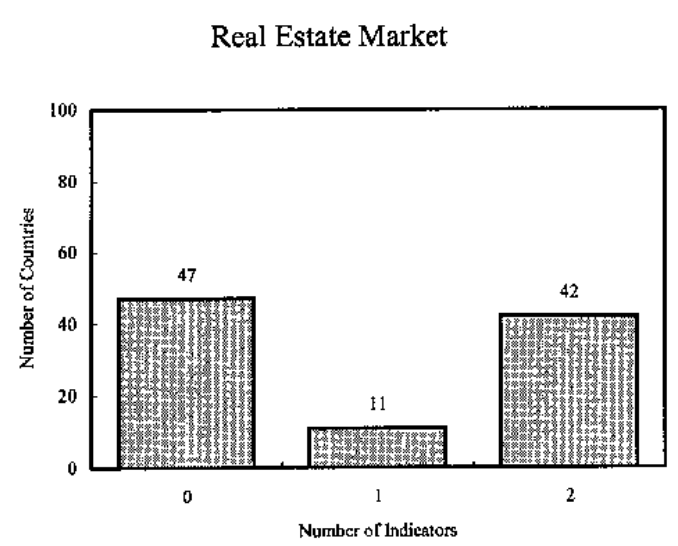

Liquidity

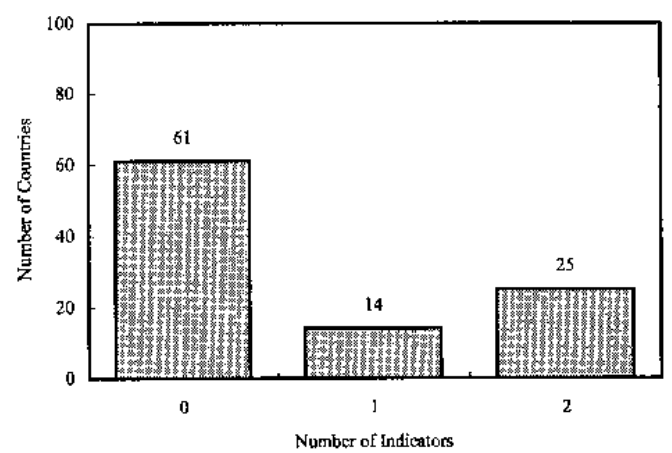

Households

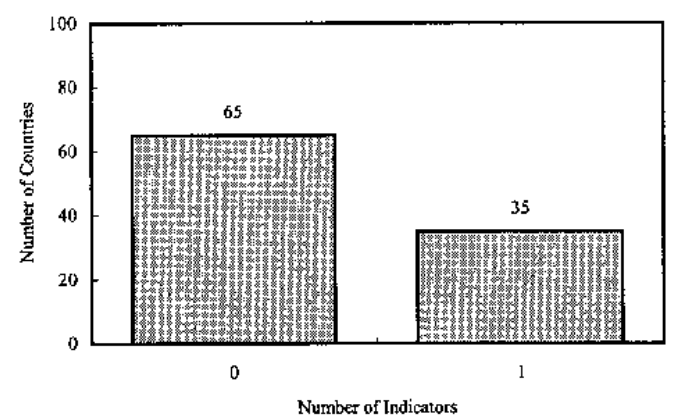

Source: IMF Survey on the Use, Compilation, and Dissemination of Macroprudential Indicators 


\section{SUMMARY OF FINDINGS}

\section{A. Collection of Data on FSIs}

- Countries typically collect data on half of the 54 FSIs surveyed but do not widely collect data on indicators drawn from outside the traditional supervisory data sources and macroeconomic statistical frameworks. As a result, they collect data on only one-third or less of the indicators on market risk and asset quality (borrowing institution), although financial vulnerabilities in these areas have been important elements in financial crises. Moreover, on a global basis, countries may typically collect data on only one-quarter of the indicators.

- National agencies in advanced, transition, and Middle Eastern economies appear to have the most developed systems in place for collecting data on FSIs, enabling them to compile more than half the indicators specified in the survey.

- Asian economies that have not experienced a banking crisis appear to have the least developed systems in place for collecting data on FSIs. Similarly, countries in the Western Hemisphere that have not experienced a banking crisis collect data on fewer FSIs than those that have experienced a banking crisis.

\section{B. Compilation of FSI Ratios}

- Countries do not always use data collected on the numerator and denominator of the FSI to compile FSI ratios. They typically use less than two-thirds of the data collected on indicators to compile FSI ratios. Asian countries use only one-third of the data collected to compile ratios. Countries are least likely, in general, to use data collected on indicators of liquidity and market risk to compile ratios.

- Western Hemisphere, African, and advanced economies that have experienced banking crises use a much larger proportion of their collected data to compile ratios than their noncrisis counterparts. By contrast, agencies in Asian crisis countries use a much smaller proportion of their collected data to compile ratios than their noncrisis counterparts. This suggests that while Asian crisis countries collect more data, they may not yet have fully integrated these into their financial vulnerability analysis.

\section{Dissemination of Data on FSIs}

- National agencies make a much smaller dataset on FSIs available to the public than they collect. Agencies in transition countries are typically the most eager to disseminate the data they collect, followed by agencies in advanced economies, Africa, and the Western Hemisphere. Agencies in Asia and the Middle East appear to be the most reluctant to disseminate the data they collect, providing the public with data on less than half the indicators on which they collect data. But differences are apparent in the eagerness of crisis and noncrisis countries to disseminate, especially for agencies in Asia. In general, national agencies appear to be typically most eager to disseminate data on 
indicators of asset quality (borrowing institution) and on profitability and competitiveness. They appear to be least eager to disseminate data on indicators of market risk.

- The Asian, African, and Western Hemisphere countries that have experienced banking crises are typically much more eager to disseminate the data they collect on FSIs than their noncrisis counterparts. This heightened eagerness to disseminate extends across all categories of FSI and across most indicators and may suggest that banking crisis countries have an elevated awareness of the benefits of data disclosure and transparency. By contrast, agencies in Middle Eastern countries that have experienced a banking crisis disseminate a smaller proportion of the data they collect than their noncrisis counterparts, across all categories of FSI.

\section{Core and Encouraged FSIs}

- A large proportion of countries collect data on 10 of the 15 core indicators included in the survey. Less widespread is the collection of data on large loans to own funds, nonperforming loans net of provisions to total assets, and net foreign currency position to own funds. Moreover, only one-fifth of countries collect data on duration of assets and liabilities. In line with the general findings noted above, there is room for agencies, especially those in Africa, Asia, and the Middle East, to increase their public dissemination of data collected on the core indicators.

- The collection of data on the encouraged indicators is less widespread than for the core set. This is especially true for indicators on the corporate and household sectors and real estate markets, with a significant number of agencies outside the advanced economies collecting data on none of these indicators. As with the core set, there is room for agencies, especially those outside Africa and transition economies, to increase their dissemination of data collected on the encouraged indicators.

\section{CONCLUSIONS}

In the short term, many countries have scope to improve the public availability of FSIs by disseminating data already collected. Over the longer term, increasing the availability of FSI data will require providing resources focused on filling the gaps in the availability of data, the spreading of knowledge on modes of efficiently collecting and compiling data, and encouraging national authorities to be more proactive in disseminating the data they collect. Given the differences across regions, and across countries within regions, in data collection, compilation, and dissemination practices, some countries will need more time and resources than others to meet these new statistical challenges.

National authorities and international and regional organizations should carefully consider concerns about market misinterpretation of the indicators and the most meaningful manner for agencies to present FSIs. In addition, key factors for success will be internationally comparable definitions of terms, as well as common guidelines on the compilation of the indicators. Work is currently underway at the IMF to prepare a Compilation Guide on 
Financial Soundness Indicators, aimed at addressing these issues. ${ }^{25}$ Given the current variations in country practices, an important element for the success of this work will be a flexible approach. It should be sensitive to local resource constraints, especially the existing statistical capacity, and to the nature of the domestic financial system, as well as the crossborder activities of locally incorporated financial institutions.

${ }^{25}$ See http://www.imf.org/external/np/sta/ssi/eng/fsi.htm for additional information. 


\section{Chronology of Banking Crises}

\begin{tabular}{|c|c|c|c|c|c|}
\hline \multirow[t]{2}{*}{ Country } & \multirow[t]{2}{*}{$\begin{array}{l}\text { Lindgren, Garcia, } \\
\text { and Saal (1996) }\end{array}$} & \multirow[t]{2}{*}{$\begin{array}{l}\text { Kaminsky and Reinhart } \\
\text { (1996) and Kaminsky (1998) }\end{array}$} & \multicolumn{2}{|c|}{$\begin{array}{l}\text { Hardy and } \\
\text { Pazarbasioglu (1998) }\end{array}$} & \multirow{2}{*}{$\begin{array}{l}\text { Demirgüç-Kunt and } \\
\text { Detragiache (1998a) } \\
\text { 1998b) } 1999\end{array}$} \\
\hline & & & Crisis & Distress & \\
\hline Algeria & & & & 1990 & \\
\hline Argentina & $1980-82,1989-90,1995$ & $1980,1985,1994$ & & & \\
\hline Benin & 1988 & & 1987 & & \\
\hline Bolivia & & 1987 & & & \\
\hline Brazil & & 1985,1994 & & & \\
\hline Bulgaria & $1991-96$ & & . & & \\
\hline Cameroon & $1989.93,1995.96$ & & 1989 & & \\
\hline Canada & & & & 1983 & \\
\hline Central African Republic & $1976-92$ & & & & \\
\hline Chad & $1979-83$ & & & & \\
\hline Chile & $1981-87$ & 1981 & & & $1981^{*}$ \\
\hline Columbia & & 1982 & & 1984 & $1982-85$ \\
\hline Congo & $1994-96$ & & 1994 & & \\
\hline Costa Rica & & & & 1994 & \\
\hline Côte d'Ívoire & & & & 1988 & \\
\hline Denmark & & 1987 & & 1990 & \\
\hline Dominican Republic & & & & 1992 & $1995^{*}$ \\
\hline Ecuador & & & & 1992 & $1989^{*}$ \\
\hline \multicolumn{6}{|l|}{ E1 Salvador } \\
\hline Equatorial Guinea & $1983-85$ & & & & \\
\hline Estonia & $1992-95$ & & & & \\
\hline Finland & $1991-94$ & 1991 & 1991 & & $1991-94$ \\
\hline France & & & & 1994 & \\
\hline Guinea & $1980-85$ & & & & \\
\hline Guyana & & & & & $1993-95$ \\
\hline Iceland & & & & 1985 & \\
\hline India & & & & & $1991-94$ \\
\hline Indonesia & & 1992 & 1997 & 1992 & $1992-94$ \\
\hline Israel & & 1983 & & & $1983-84$ \\
\hline Italy & & & & & $1990-94$ \\
\hline Jamaica & & & & 1994 & \\
\hline Japan & & & & 1992 & $1992-94$ \\
\hline Jordan & $1989-90$ & & & 1989 & $1989-90$ \\
\hline Kenya & & & & 1993 & 1993 \\
\hline Korea & & & 1997 & & \\
\hline Kuwait & mid-1980s & & & & \\
\hline Latvia & $1995-96$ & & & & \\
\hline Lebanon & $1988-90$ & & & & \\
\hline Liberia & $1991-95$ & & & & \\
\hline Lithuania & $1995-96$ & & & & \\
\hline Macedonia, FYR of & $1993-94$ & & & & \\
\hline Madagascar & & & & & 1988 \\
\hline Malaysia & $1985-88$ & 1985 & 1985 & & $1985-88$ \\
\hline Mali & & & & 1987 & $1987-89$ \\
\hline Mexico & $1982,1994-96$ & 1982,1992 & 1982,1994 & & 1982,1994 \\
\hline Nepal & & & & & $1988-94$ \\
\hline New Zealand & & & & 1989 & \\
\hline Niger & $1983-96$ & & & & \\
\hline Nigeria & & & & & $1991-94$ \\
\hline Norway & $1987-93$ & 1988 & 1991 & & $1987-93$ \\
\hline Panama & $1988-89$ & & & & $1988^{*}$ \\
\hline Papua New Guinea & & & & & 1989 \\
\hline Paraguay & & & & 1995 & \\
\hline Peru & & 1983 & & 1983 & $1983^{*}$ \\
\hline Philippines & $1981-87$ & 1981 & 1981 & 1997 & $1981-87$ \\
\hline Portugal & & & & & $1986^{*}$ \\
\hline Sao Tomé and Principe & $1980-96$ & & & & \\
\hline
\end{tabular}




\begin{tabular}{|c|c|c|c|c|c|}
\hline \multirow[t]{2}{*}{ Country } & \multirow[t]{2}{*}{$\begin{array}{l}\text { Lindgren, Garcia, } \\
\text { and Saal (1996) }\end{array}$} & \multirow[t]{2}{*}{$\begin{array}{l}\text { Kaminsky and Reinhart } \\
\text { (1996) and Kaminsky (1998) }\end{array}$} & \multicolumn{2}{|c|}{$\begin{array}{l}\text { Hardy and } \\
\text { Pazarbasioglu (1998) }\end{array}$} & \multirow{2}{*}{$\begin{array}{l}\text { Demirgüç-Kunt and } \\
\text { Detragiache (1998a) } \\
\text { 1998b) } 1999\end{array}$} \\
\hline & & & Crisis & Distress & \\
\hline Senegal & $1983-88$ & & 1983 & & $1983-88^{* *}$ \\
\hline Somalia & 1990 & & & & \\
\hline South Africa & 1985 & & 1985 & 1989 & 1985 \\
\hline Spain & 1977.85 & 1978 & & & \\
\hline Sri Lanka & & & & & $1989-93$ \\
\hline Swaziland & & & & & $1995^{*}$ \\
\hline Sweden & $1990-93$ & 1991 & 1992 & & $1990^{*}$ \\
\hline Tanzania & $1988-96$ & & & & $1988-94^{* *}$ \\
\hline Thailand & $1983-87$ & 1979,1983 & 1983,1987 & & $1983^{*}$ \\
\hline Togo & & & & 1989 & \\
\hline Turkey & 1982,1991 & $199 \mathrm{I}$ & 1982 & & $1991-1994$ \\
\hline Uganda & & & & & $1990-94^{* *}$ \\
\hline United States & & & & & $1980^{*}$ \\
\hline Uruguay & $1981-85$ & 1971,1981 & & 1982 & $1981-85$ \\
\hline Venezuela & $1994-96$ & 1993 & 1994 & & $1993-94$ \\
\hline Total no. of countries involved & 36 & 20 & 16 & 25 & 36 \\
\hline & & & & & \\
\hline & & & & & \\
\hline 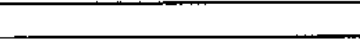 & & & & & \\
\hline
\end{tabular}

*Included only in Demirguc-Kunt and Detragiache (1999); **Included only in Demirguc-Kunt \& Detragiache (1998a) and (1998b)

Source: Bank of England, 2000, Financial Stability Review, Issue 9 (December). 
Table 1. Collection of Data on Financial Soundness Indicators (2000) 1/

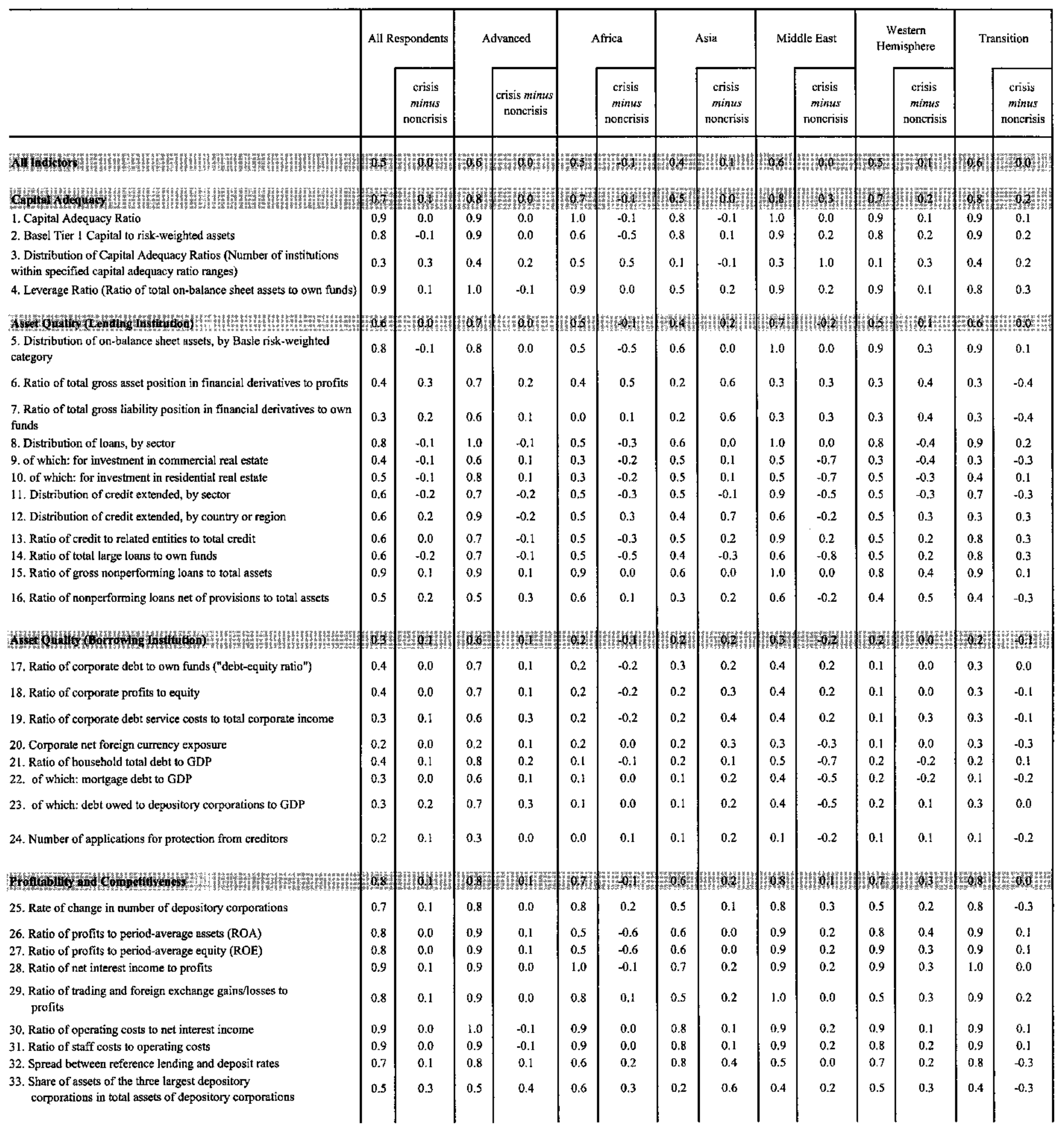


Table 1. Collection of Data on Financial Soundness Indicators (2000) 1/

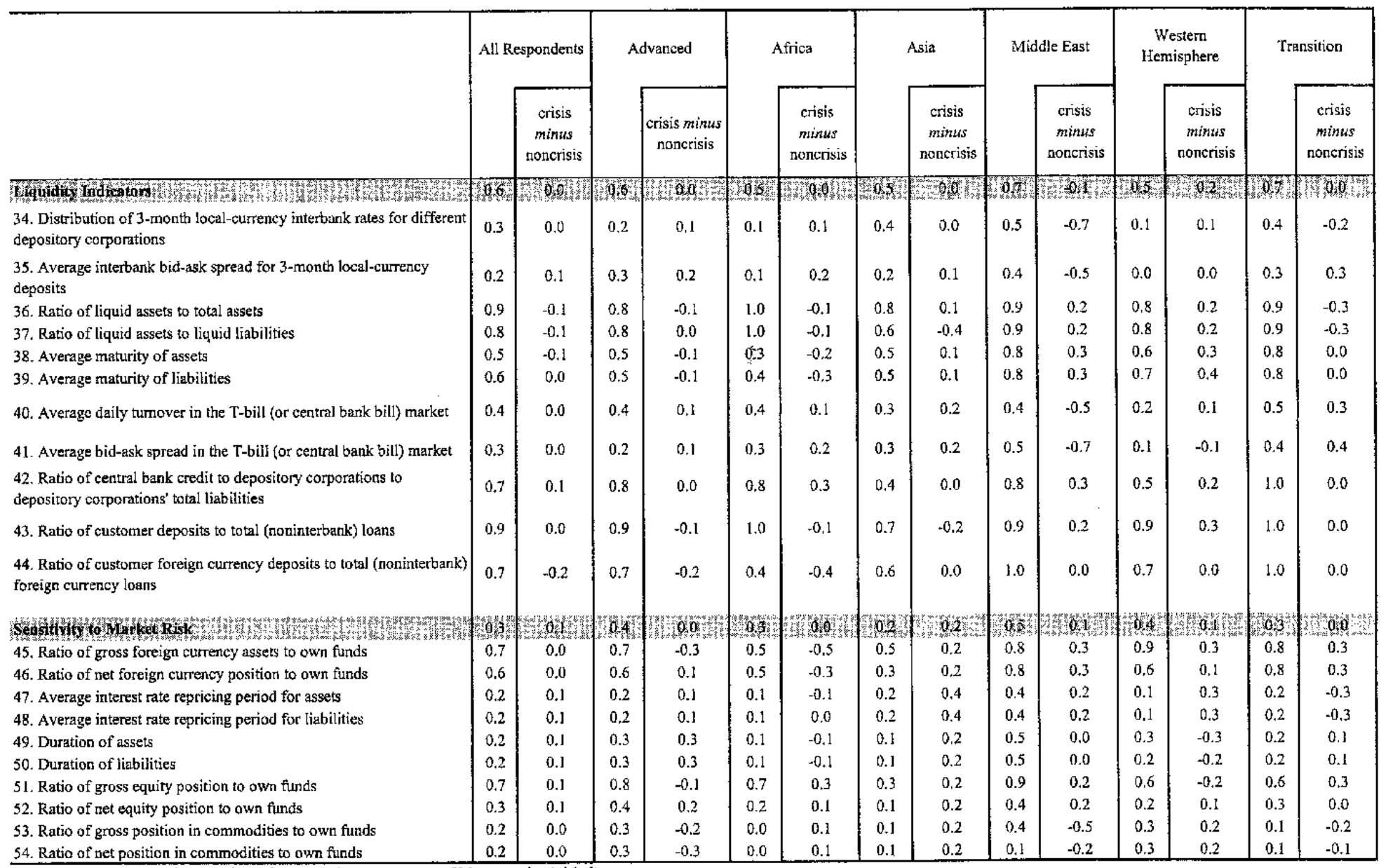

Source: IMF Survey on the Use, Compilation, and Dissemination of Macroprudential Indicators. 
Table 2. Dissemination of Data on Financial Soundness Indicators (2000) 1 /

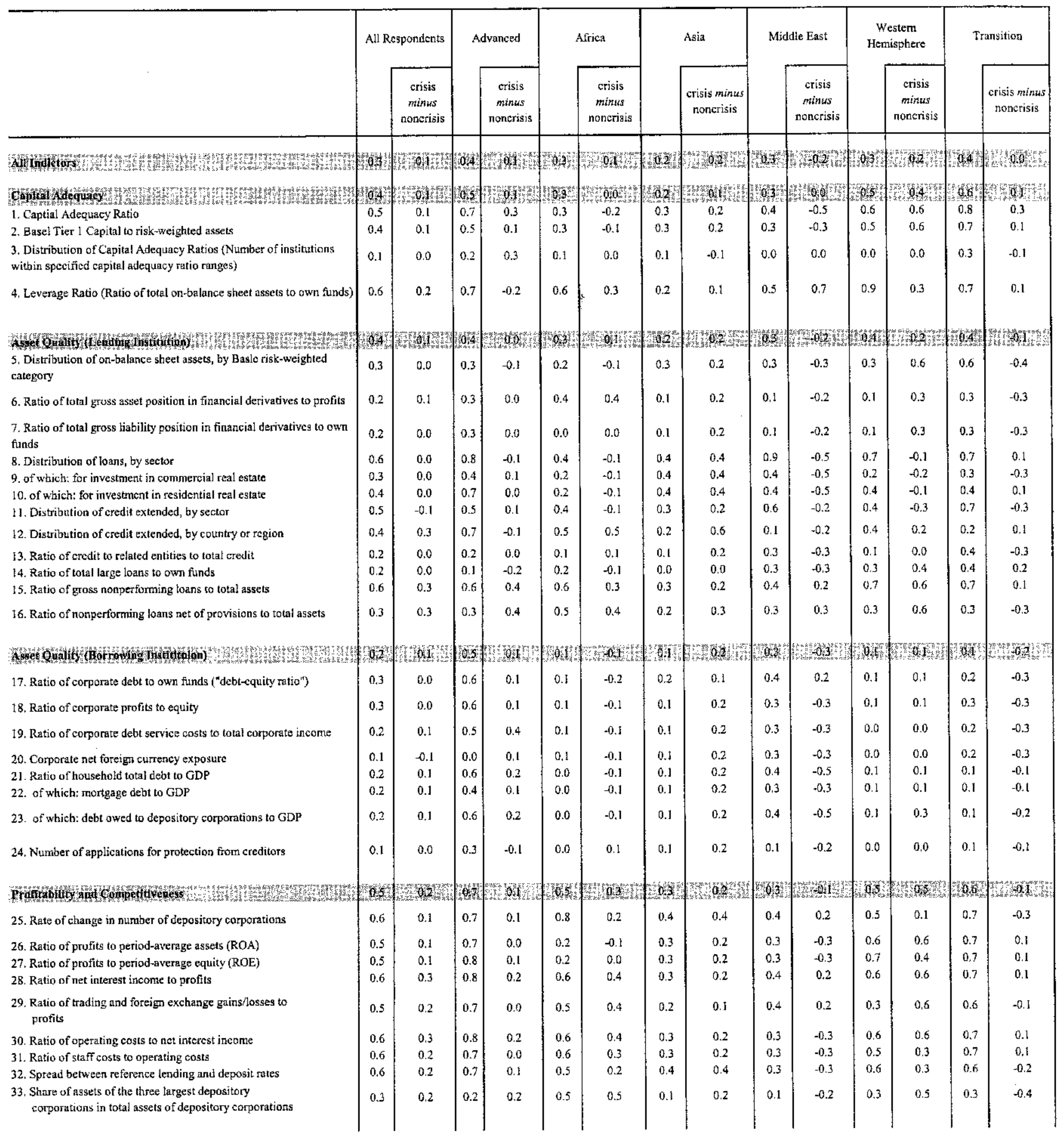


Table 2. Dissemination of Data on Financial Soundness Indicators (2000) 1/

\begin{tabular}{|c|c|c|c|c|c|c|c|c|c|c|c|c|c|c|}
\hline & \multicolumn{2}{|c|}{ Ail Respondents } & \multicolumn{2}{|c|}{ Advanced } & \multicolumn{2}{|r|}{ Africa } & \multicolumn{2}{|r|}{ Asia } & \multicolumn{2}{|c|}{ Mičdle East } & \multicolumn{2}{|c|}{$\begin{array}{c}\text { Westem } \\
\text { Hemisphere }\end{array}$} & \multicolumn{2}{|c|}{ Transition } \\
\hline & & $\begin{array}{c}\text { crisis } \\
\text { ntinus } \\
\text { noncrisis }\end{array}$ & & $\begin{array}{c}\text { crisis } \\
\text { minus: } \\
\text { nonturisis }\end{array}$ & & $\begin{array}{c}\text { erisis } \\
\text { mintur } \\
\text { noncrisis }\end{array}$ & & $\begin{array}{c}\text { crisis mintes } \\
\text { nonerisis }\end{array}$ & & $\begin{array}{c}\text { urisis } \\
\text { minus } \\
\text { nencrisis }\end{array}$ & & $\begin{array}{c}\text { crisis } \\
\text { minus } \\
\text { noncrisis }\end{array}$ & & $\begin{array}{c}\text { crisis minus } \\
\text { noncrisis }\end{array}$ \\
\hline 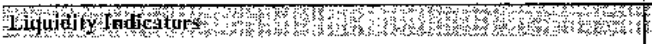 & $0 ; 3:$ & Wo 0 & 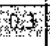 & \% & 033 & W $01+2$ & if 2 & and & 03 & Whe & 0 & Sol & $60 \times$ & 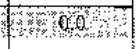 \\
\hline $\begin{array}{l}\text { 34. Distribution of 3-month tocal-currency inicrbink takes for different } \\
\text { depository comprations }\end{array}$ & 0,1 & 0.0 & 0.1 & 0.9 & 0.1 & 0.1 & 0.2 & 0.1 & 0.3 & -0.3 & 0.1 & 0.1 & 0.3 & -0.3 \\
\hline $\begin{array}{l}\text { 35. Average interbank bid-ask spread tor 3-month local-currency } \\
\text { deposits }\end{array}$ & 0.1 & 0.0 & 0.1 & 0.0 & 0.1 & 0.2 & 0.1 & 0.2 & 0.3 & -0.3 & 0.0 & 0.0 & 0.2 & 0.1 \\
\hline 36. Ratio of liquid assets to total assets & $0 . \div$ & -0.1 & 0.4 & -0.1 & 0.3 & 0.0 & 0.3 & 0.2 & 0.3 & -0.3 & 0.5 & -0.1 & 0.7 & -0.2 \\
\hline 37. Ratio of liquid assets to liquid liabilities & 0.4 & -3.1 & 0.4 & 0.0 & 0.3 & 0.0 & 0.2 & -0.1 & 0.3 & -3.3 & 0.5 & -0.1 & 0.7 & -4.3 \\
\hline 38. Average maturity of assets & 0.2 & 0.0 & 0.1 & -0.1 & 0.2 & 0.0 & 0.2 & 0.1 & 0.3 & -0.3 & 0.3 & 0.2 & 0.5 & 0.3 \\
\hline 39. Average maturity of :iabilities & 0.2 & 0.0 & 0.1 & -0.1 & 0.2 & $=0.0$ & 0.2 & 6.1 & 0.3 & -0.3 & 0.3 & 0.2 & 0.5 & 0.3 \\
\hline 40. Averige daily turnover in the T-bill (or central bank biil) market & 0.3 & 0.0 & 0.3 & 0.1 & 0.3 & 0.2 & 0.2 & 0.1 & 0.1 & $-0,2$ & 0.1 & 0.0 & 0.4 & 0.1 \\
\hline 41. Average bid-ask sp̧read in the T-bill (or central bank bill) marke! & 0.1 & 0.0 & 0.0 & -0.1 & 0.2 & 0.4 & 0.2 & 0.1 & 0.3 & -0.3 & 0.0 & 0.0 & 0.3 & 0.2 \\
\hline $\begin{array}{l}\text { 42. Ratio of central banx credit to depository corporations to } \\
\text { depository corporations' total liabilities }\end{array}$ & 0.5 & 0.2 & 0.6 & 0.3 & 0.7 & 0.3 & 0.2 & -0.1 & 0.5 & 0.7 & 0.3 & 0.0 & 0.7 & 0.4 \\
\hline 43. Ratio of eustomer deposits to total (noninterbank) loans & 0.7 & 0.1 & 0.3 & -0.1 & 0.7 & 0.1 & 9.5 & 0.2 & 0.6 & 0.5 & 0.5 & 0.5 & 0.9 & 0.2 \\
\hline $\begin{array}{l}\text { 44. Ratio of sustomer foreign currency deposits to total (noninterbank) } \\
\text { forcign currency loans }\end{array}$ & 0.5 & 0.0 & 0.6 & 0.1 & 0.2 & -0.2 & 0.3 & -0.2 & 0.4 & 0.2 & 0.4 & 0.2 & 0.3 & 0.0 \\
\hline Senstivith to Manket Misk & $2 z$ & Yor & 02 & $000 \%$ & 60 & 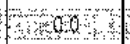 & 0 & $6=02,1$ & meg. & In $=0.14$ & 01 & molo & 33 & 00 \\
\hline 45. Ratio of gross foreign currency assets to own funds & 0.2 & $0 . i$ & 0.5 & 0.0 & 0.1 & 0.0 & 0.1 & 0.1 & 0.2 & 0.1 & 0.2 & 0.0 & 0.4 & 0.5 \\
\hline 46. Ratio of net foreign currency pesition to own funds & 0.3 & 0.0 & 0.2 & 0.1 & 0.2 & .0 .1 & 0.1 & 0.2 & 0.3 & .0 .3 & 0.3 & 0.0 & 0.6 & -0.1 \\
\hline 47. Average interest rate repricing period for assets & 0.1 & 0.0 & 0.0 & 0.1 & 0.0 & -0.1 & 0.1 & 0.2 & 0.1 & -0.2 & 0,0 & 0,0 & 0.1 & -0.1 \\
\hline 48. Average interest rate repricing period for liabilities & 0.0 & 0.0 & 0.0 & 0.1 & 0.0 & 0.0 & 0.1 & 0.2 & 3.1 & -0.2 & 0.0 & 0.0 & 0.1 & -0.1 \\
\hline 49. Duration of assets & 0.1 & -0.1 & 0.1 & 0.0 & 0.0 & 0,0 & 0.1 & 0.2 & 0.3 & 0.3 & 0.1 & -10.3 & 0.2 & 0.1 \\
\hline 50. Duration of liabilities & 0.1 & 0.0 & 0.1 & 0.0 & 0.0 & 0.0 & 0.1 & 0.2 & 0.3 & -0.3 & 0.1 & -0.1 & 0.2 & 0.1 \\
\hline 51. Ratio of gross equity position to own funds & 0.4 & 0.2 & 0,5 & -2.1 & 0.5 & 0.5 & 0.1 & 0.2 & 0.3 & 0.3 & 0.2 & 0.1 & 0,4 & 0.1 \\
\hline 52. Ratio of net equity position to own funds & 0.1 & 0.1 & 0,1 & 0.0 & 0.1 & 0.1 & 0.1 & 0,2 & 0.3 & 0.3 & 0.1 & 0.0 & 0.2 & 0.1 \\
\hline 53. Ratio of gross positiun in commodities to own funds & 0.1 & 0.1 & 0.1 & 0.1 & 0.0 & 0.0 & 0.1 & 0.2 & 0.0 & 0.0 & 0.1 & 0.3 & 0.1 & -0.2 \\
\hline 54. Ratio of net position in commodities to own funds & 0.1 & 0.1 & 0.1 & 0.0 & 0.0 & 0.0 & 0.1 & 0.2 & 0.0 & 0.0 & 0.1 & 0.3 & 0.1 & -0.1 \\
\hline
\end{tabular}

Source: JMF Survev on the Use. Compliation, and Dissemination of Macroprtidential Yndicators. 
Table 3. Eagerness to Disseminate Data on Financial Soundness Indicators (2000) $1 / 2 /$

\begin{tabular}{|c|c|c|c|c|c|c|c|c|c|c|c|c|c|c|}
\hline & All Re & spondents & & Adyanced & & Africa & & Asia & & liddle East & Westem $\mathrm{H}$ & Hemisphere & & Transition \\
\hline & & $\begin{array}{c}\text { crisis } \\
\text { minus } \\
\text { nonctisis }\end{array}$ & & $\begin{array}{c}\text { crisis minus } \\
\text { noncrisis }\end{array}$ & & $\begin{array}{c}\text { crisis } \\
\text { minus } \\
\text { noncrisis }\end{array}$ & & $\begin{array}{c}\text { crisis minus } \\
\text { noncrisis }\end{array}$ & & $\begin{array}{c}\text { trisis } \\
\text { minus } \\
\text { noncrisis }\end{array}$ & & $\begin{array}{c}\text { crisis } \\
\text { mintss } \\
\text { nonctisis }\end{array}$ & & $\begin{array}{c}\text { crisis } \\
\text { minus } \\
\text { noncrisis }\end{array}$ \\
\hline 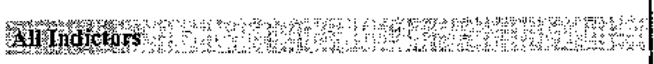 & $x_{10 x}$ & 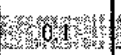 & 0,6 & 1) & 66 & & 6.9 & 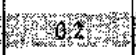 & 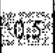 & & 6 & & 6 & bithos \\
\hline 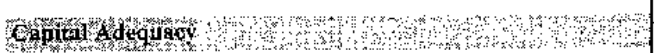 & 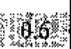 & Wom & 6 & W & 005 & - $-1 \mathrm{~cm}$ & 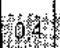 & wat & 6 & W & \% & 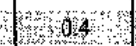 & K & 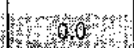 \\
\hline I. Captial Adequacy Ratio & 0.6 & 0.2 & 0.8 & 0.3 & 0.3 & -0.2 & 0.4 & 0.2 & 0.4 & -0.5 & 0.6 & 0.5 & 0.8 & 0.3 \\
\hline 2. Basel Tier I Capital to risk-weightec assets & 0.5 & 0.2 & 0.6 & 0.1 & 0.5 & $=0.3$ & 0.4 & 0.2 & 0.3 & $-0,4$ & 0.6 & 0.7 & 0.8 & 0.0 \\
\hline $\begin{array}{l}\text { 3. Distribution of Capital Adequacy Ratios (Number of institutions } \\
\text { within specified capital adequacy ratio ranges) }\end{array}$ & 0.4 & -0.2 & 0.4 & 0.6 & 0.2 & -0.2 & 1.0 & $\begin{array}{l}\text { data not } \\
\text { collected }\end{array}$ & 0.0 & $\begin{array}{l}\text { data not } \\
\text { collected }\end{array}$ & 0.0 & $\begin{array}{l}\text { data not } \\
\text { collected }\end{array}$ & 0.8 & -0.5 \\
\hline $\begin{array}{l}\text { 4. Severage Ratio (Ratio of total on-balance sheet assets to own } \\
\text { funds) }\end{array}$ & 0.7 & 0.1 & 0.8 & -0.1 & 0.7 & 0.3 & 0.3 & 0.0 & 0.6 & 0.6 & 0.9 & 0.2 & 0.8 & $-0 . !$ \\
\hline 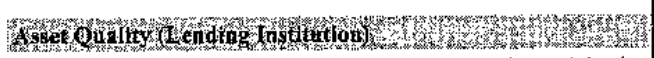 & 06 & 6 & 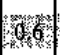 & Whom & (6) & 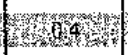 & 5 & 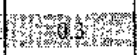 & orto & 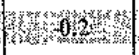 & & (y) & 6 & 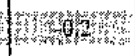 \\
\hline $\begin{array}{l}\text { 5. Distribution of on-balance sheet assets, by Basle risk-weighted } \\
\text { category }\end{array}$ & 0.4 & 0.0 & 0.4 & -0.1 & 0.4 & 0.3 & 0.5 & 0.3 & 0.3 & .0 .3 & 0.4 & 0.6 & 0.6 & -0.5 \\
\hline $\begin{array}{l}\text { 6. Ratio of total gross asset position in financial derivatives to } \\
\text { profits }\end{array}$ & 0.6 & -0.2 & 0.4 & -0.1 & 0.9 & -0.1 & 0.3 & $\begin{array}{l}\text { data not } \\
\text { collected }\end{array}$ & 0.5 & $-1,0$ & 0.4 & 0.5 & 0.8 & $\begin{array}{l}\text { data not } \\
\text { collected }\end{array}$ \\
\hline $\begin{array}{l}\text { 7. Ratio of total gross liability position in financial derivatives to } \\
\text { own funds }\end{array}$ & 0.5 & -0.2 & 0.4 & -0.1 & 0.0 & $\begin{array}{l}\text { data nol } \\
\text { collected }\end{array}$ & 0.3 & $\begin{array}{l}\text { daca not } \\
\text { collected }\end{array}$ & 0.5 & -1.0 & 0.4 & 0.5 & 0.8 & $\begin{array}{l}\text { data not } \\
\text { collected }\end{array}$ \\
\hline 8. Distribution of loans, by sector & 0.8 & 0.1 & 0.9 & .0 .1 & 0.8 & 0.3 & 0.6 & 0.6 & 0.9 & -0.5 & 0.8 & 0.3 & 0.8 & 0,0 \\
\hline 9. of which: for investnteth in commercial real estate & 0.7 & 0.2 & 0.7 & 0.1 & 0.7 & 0.4 & 0.7 & 0.5 & 0.8 & $\begin{array}{l}\text { data not } \\
\text { collected }\end{array}$ & 0.6 & 0.5 & 1.0 & $\begin{array}{l}\text { data not } \\
\text { collected }\end{array}$ \\
\hline 10. of which: for investment in residential real estate & 0.8 & 0.2 & 0.9 & 0.0 & 0.7 & 0.4 & 0.7 & 0.5 & 0.8 & $\begin{array}{l}\text { data no: } \\
\text { collected }\end{array}$ & 0.8 & 0.4 & 1.0 & 0.0 \\
\hline 11. Distribution of credit extended, by sector & 0.8 & 0.1 & 0.7 & 0.2 & 0.8 & 0.3 & 0.7 & 0.5 & 0.7 & 0.3 & 0.8 & -0.1 & 1.0 & 0.0 \\
\hline 12. Distribution of credit extended, by country or region & 0.7 & 0.2 & 0.8 & 0.1 & 0.8 & 0.4 & 0.6 & 0.8 & 0.2 & -0.3 & 0.9 & -0.2 & 0.6 & -0.2 \\
\hline 13. Ratio of credic to related cntities to total credit & 0.3 & 0.0 & 0.3 & 0.1 & 0.3 & 0.5 & 0.2 & 0.3 & 0.3 & -0.4 & 0.3 & -0.1 & 0.5 & -0.4 \\
\hline 14. Ratio of total large loans to own funcs & 0.3 & 0.0 & 0.1 & -0.3 & 0.4 & 0.3 & 0.0 & 0.0 & 0.4 & $\begin{array}{l}\text { data not } \\
\text { collected }\end{array}$ & 0.6 & 0.5 & 0.5 & 0.0 \\
\hline 15. Ratio of gross nonperforming loans to tocal assets & 0.7 & 0.3 & 0.7 & 0.3 & 0.7 & 0.3 & 0.5 & 0.3 & 0.4 & 0.2 & 0.9 & 0.3 & 0.7 & 0.0 \\
\hline 16. Ratio of nonperforming loans net of provisions to total assets & 0.7 & 0.4 & 0.6 & 0.5 & 0.8 & 0.4 & 0.8 & 0.5 & 0.4 & 0.8 & 0.8 & 1.0 & 0.6 & -0.7 \\
\hline 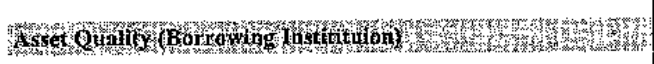 & W & Fis: & 0 & 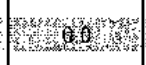 & 0 & $\mid x+2$ & 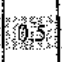 & Wats & $\log ^{2}$ & 类 & Wh & W & 6) & 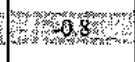 \\
\hline 17. Ratio of corporate debt to own funds ("debt-equity ratio") & 0.8 & 0.0 & 0.9 & 0.1 & 0.4 & -0.5 & 0.5 & 0.0 & 1.0 & 0.0 & 0.5 & 1.0 & 0.8 & -1.0 \\
\hline 18. Ratio of corporate profits to equity & 0.8 & 0.0 & 0.9 & 0.1 & 0.6 & 0.5 & 0.3 & 0.5 & 0.7 & -1.0 & 0.5 & 1.0 & 0.8 & -1.0 \\
\hline 19. Ratio of corporate debt service costs to total corporate incorne & 0.7 & 0.0 & 0.8 & 0.3 & 0.6 & 0.5 & 0.5 & $\begin{array}{l}\text { data not } \\
\text { collected }\end{array}$ & 0.7 & -1.0 & 0.0 & $\begin{array}{l}\text { data not } \\
\text { collected }\end{array}$ & 0.6 & -0.8 \\
\hline 20. Corporate net foreign currency exposure & 0.5 & -0.3 & 0.3 & 0.3 & 0.8 & -0.5 & 0.3 & 0.5 & 1.0 & $\begin{array}{l}\text { data not } \\
\text { collected }\end{array}$ & 0.0 & 0.0 & 0.8 & $\begin{array}{l}\text { data not } \\
\text { collected }\end{array}$ \\
\hline 21. Ratio of household total debt to GDP & 0.6 & 0.2 & 0.8 & 0.1 & 0.3 & -0.5 & 0.5 & 1.0 & 0.8 & $\begin{array}{l}\text { data not } \\
\text { collected }\end{array}$ & 0.3 & 1.0 & 0.3 & -0.5 \\
\hline 22. of which: mortgage debt to GDP & 0.7 & 0.2 & 0.7 & 0.1 & 0.5 & -1.0 & 1.0 & $\begin{array}{l}\text { data not } \\
\text { collected }\end{array}$ & 0.7 & $\begin{array}{l}\text { data not } \\
\text { collected }\end{array}$ & 0.3 & 1.0 & 0.5 & $\begin{array}{l}\text { data not } \\
\text { collected }\end{array}$ \\
\hline 23. of which: debt owed to depository corporations to GDP & 0.8 & -0.1 & 0.9 & -0.2 & 0.5 & -1.0 & 1.0 & $\begin{array}{l}\text { data not } \\
\text { collected }\end{array}$ & 1.0 & $\begin{array}{l}\text { data not } \\
\text { collected }\end{array}$ & 0.7 & 1.0 & 0.5 & -0.7 \\
\hline 24. Number of applications for protection from creditors & 0.8 & -0.1 & 0.9 & -0.2 & 1.0 & $\begin{array}{l}\text { data not } \\
\text { collected }\end{array}$ & 1.0 & $\begin{array}{l}\text { ćata not } \\
\text { collected }\end{array}$ & 1.0 & $\begin{array}{l}\text { data not } \\
\text { collected }\end{array}$ & 0.0 & $\begin{array}{l}\text { cata not } \\
\text { collected }\end{array}$ & 0.5 & $\begin{array}{l}\text { duta not } \\
\text { collected }\end{array}$ \\
\hline 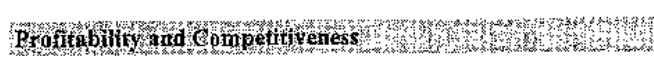 & $\log x$ & Hen & o & (1) & o & 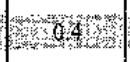 & 6 & 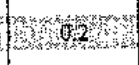 & 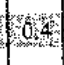 & -02, & $\log _{2}$ & Whend 040 & (6.2. & 00 \\
\hline 25. Rate of change in number of depository corporations & 0.8 & 0.1 & 0.8 & 0.1 & 1.0 & 0.0 & 0.7 & 0.5 & 0.5 & 0.0 & 0.9 & -0.2 & 0.9 & 0.1 \\
\hline 26. Ratio of profits to period-average aszets (ROA) & 0.6 & 0.2 & 0.8 & -3.1 & 0.4 & 0.7 & 0.5 & 0.3 & 0.3 & -0.4 & 0.8 & 0.4 & 0.7 & 0.0 \\
\hline 27. Racio of profits to period-average equity (ROE) & 0.7 & 0.2 & 0.9 & 0.0 & 0.4 & 0.8 & 0.5 & 0.3 & 0.3 & -0.4 & 0.8 & 0.3 & 0.7 & 0.0 \\
\hline 28. Ratio of net interest income to prolits & 0.7 & 0.3 & 0.8 & 0.2 & 0.6 & 0.5 & 0.4 & 0.1 & 0.4 & 0.1 & 0.7 & 0.5 & 0.7 & 0.1 \\
\hline
\end{tabular}


Table 3. Eagerness to Disseminate Data on Financial Soundness Indicators (2000) $1 / 2 /$

\begin{tabular}{|c|c|c|c|c|c|c|c|c|c|c|c|c|c|c|}
\hline & \multicolumn{2}{|c|}{ Alt Respondents } & \multicolumn{2}{|r|}{ Advanced } & \multicolumn{2}{|r|}{ Africa } & \multicolumn{2}{|r|}{ Asia } & \multicolumn{2}{|c|}{ Middle East } & \multicolumn{2}{|c|}{ Westen Hemisphere } & \multicolumn{2}{|r|}{ Transition } \\
\hline & & $\begin{array}{c}\text { crisis } \\
\text { minus } \\
\text { noncrisis }\end{array}$ & & $\begin{array}{c}\text { crisis minus } \\
\text { noncrisis }\end{array}$ & & $\begin{array}{c}\text { crisis } \\
\text { mints } \\
\text { noncrisis }\end{array}$ & & $\begin{array}{c}\text { crisis minus } \\
\text { noncrisis }\end{array}$ & & $\begin{array}{l}\text { crisis } \\
\text { mintus } \\
\text { moncrisis }\end{array}$ & & $\begin{array}{c}\text { crisis } \\
\text { minus } \\
\text { noncrisis }\end{array}$ & & $\begin{array}{c}\text { crisis } \\
\text { minus } \\
\text { noncrisis }\end{array}$ \\
\hline $\begin{array}{l}\text { 29. Ratio of trading and foreign exchange gains/losses to } \\
\text { profits }\end{array}$ & 0.6 & 0.2 & 0.7 & 0.1 & 0.6 & 0.4 & 0.3 & 0.0 & 0.4 & 0.2 & 0.7 & 1.0 & 0.6 & -0.2 \\
\hline 30. Ratio of operating costs to net interest income & 0.6 & 0.3 & 0.8 & 0.3 & 0.7 & 0.4 & 0.4 & 0,2 & 0.3 & -0.4 & 0.6 & 0.5 & 0.7 & 0.0 \\
\hline 31. Ratio of staff costs to operating costs & 0.6 & 0.2 & 0.7 & 0.1 & 0.7 & 0.3 & 0.4 & 0.2 & 0.3 & -0.4 & 0.6 & 0.3 & 0.7 & 0.0 \\
\hline 32. Spread between reference lending and deposit rates & 0.8 & 0.1 & 0.9 & 0.0 & 0.8 & 0.0 & 0.5 & 0.2 & 0.5 & -0.7 & 0.9 & 0.3 & 0.8 & 0.2 \\
\hline $\begin{array}{l}\text { 33. Share of assets of the three largest depository } \\
\text { corporations in total assets of depository corporations }\end{array}$ & 0.6 & 0.1 & 0.5 & 0.2 & 0.7 & 0.4 & 0.3 & $\begin{array}{l}\text { data not } \\
\text { collected }\end{array}$ & 0.3 & -0.5 & 0.6 & 0.8 & 0.7 & -0.8 \\
\hline 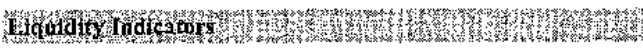 & 0 & 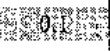 & 0 & 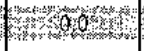 & 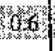 & (1) & 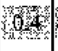 & 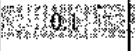 & 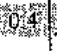 & 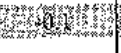 & \% & 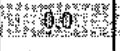 & 6 & (8) \\
\hline $\begin{array}{l}\text { 34. Distribution of 3-month local-currency interbank rates for } \\
\text { different depository corporations }\end{array}$ & 0.6 & -0.1 & 0.3 & -0.3 & 1.0 & 0.0 & 0.4 & 0.2 & 0.5 & $\begin{array}{l}\text { data not } \\
\text { collected }\end{array}$ & 1.0 & $\begin{array}{l}\text { data not } \\
\text { collected }\end{array}$ & 0.7 & -0.8 \\
\hline $\begin{array}{l}\text { 35. Average interbank bid-ask spread for 3-month local-currency } \\
\text { deposits }\end{array}$ & 0.6 & 0.0 & 0.4 & -0.1 & 1,0 & $\begin{array}{l}\text { data not } \\
\text { collected }\end{array}$ & 0.5 & 1.0 & 0.7 & $\begin{array}{l}\text { dala not } \\
\text { cullected }\end{array}$ & $\begin{array}{l}\text { data not } \\
\text { collected }\end{array}$ & $\begin{array}{l}\text { data not } \\
\text { collected }\end{array}$ & 0.6 & -0.2 \\
\hline 36. Ratio of liquid assets to total assets & 0.5 & -0.1 & 0.5 & 0.0 & 0.3 & 0.0 & 0.4 & 0.2 & 0.3 & -0.4 & 0.7 & -0.2 & 0.7 & -0.1 \\
\hline 37. Ratio of liquid assets to liquid liabilities & 0.5 & -0.1 & 0.5 & 0.1 & 0.3 & 0.0 & 0.4 & 0.2 & 0.3 & $-0,4$ & 0.7 & -0.2 & 0.7 & -0.1 \\
\hline 38. Average maturity of assets & 0.4 & 0.0 & 0.3 & -0.2 & 0.6 & 0.6 & 0.3 & 0.1 & 0.3 & -0.5 & 0.4 & 0.2 & 0.7 & 0.4 \\
\hline 39. Average maturity of liabilities & 0.4 & 0.0 & 0.3 & -0.2 & 0.5 & 0.7 & 0.3 & 0.1 & 0.3 & -0.5 & 0.4 & 0.1 & 0.7 & 0.4 \\
\hline $\begin{array}{l}\text { 40. Average daily turnover in the T-bill (or central bank bill) } \\
\text { market }\end{array}$ & 0.7 & 0.0 & 0.7 & -0.1 & 0.8 & 0.5 & 0.5 & 0.0 & 0.3 & $\begin{array}{l}\text { data not } \\
\text { collected }\end{array}$ & 0.7 & -0.5 & 0.9 & -0.3 \\
\hline $\begin{array}{l}\text { 41. Average bid-ask spread in the T-bill (or central bank bill) } \\
\text { market }\end{array}$ & 0.5 & -0.1 & 0.2 & -0.5 & 0.7 & 1.0 & 0.5 & 0,0 & 0.5 & $\begin{array}{l}\text { data not } \\
\text { collected }\end{array}$ & 0.0 & $\begin{array}{l}\text { data not } \\
\text { collec:ed }\end{array}$ & 0.7 & -0.3 \\
\hline $\begin{array}{l}\text { 42. Ratio of central bank credit to depository corporations to } \\
\text { depository corpurations' total liabilities }\end{array}$ & 0.7 & 0.2 & 0.8 & 0.4 & 0.9 & 0.0 & 0.6 & -0.2 & 0.7 & 0.5 & 0.5 & -0.3 & 0.7 & 0.4 \\
\hline 43. Ratio of customer deposits to total (nonirterbank) loans & 0,8 & 0.2 & 0.8 & 0.0 & 0.8 & 0.2 & 0.7 & 0.5 & 0.7 & 0.4 & 0.6 & 0.4 & 0.9 & 0.3 \\
\hline $\begin{array}{l}\text { 44. Ratio of customer foreign currency deposits to total } \\
\text { (noninterbank) foreign currency loans }\end{array}$ & 0.6 & 0.1 & 0.8 & 0.2 & 0.6 & -0.1 & 0.5 & -0.3 & 0.4 & 0.2 & 0.5 & 0.3 & 0.8 & 0.0 \\
\hline 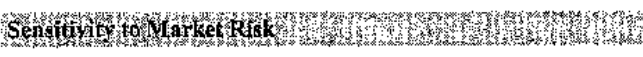 & 10 & 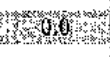 & 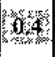 & 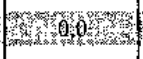 & 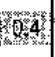 & 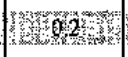 & o & 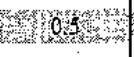 & 0 & and & Whas & Y) & Op & 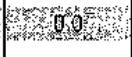 \\
\hline 45. Ratio of gross foreign curtency assets to own funds & 0.3 & 0.1 & 0.7 & 0.2 & 0.1 & 0.2 & 0.2 & 0.1 & 0.3 & 0.0 & 0.2 & -0.1 & 0.5 & 0.4 \\
\hline 46. Ratio of net foreign currency position to own funds & 0.5 & -0.1 & 0.4 & 0.1 & 0.5 & 0.2 & 0.3 & 0.5 & 0.3 & -0.5 & 0.4 & -0.1 & 0.7 & -0.3 \\
\hline 47. Average interest rate rcpricing period for assets & 0.3 & -0.1 & 0.2 & 0.3 & 0.3 & -0.5 & 0.5 & $\begin{array}{l}\text { data not } \\
\text { collected }\end{array}$ & 0.3 & -0.5 & 0.0 & $\begin{array}{l}\text { data not } \\
\text { collected }\end{array}$ & 0.3 & $\begin{array}{l}\text { daca not } \\
\text { collected }\end{array}$ \\
\hline 48. Average interest tate repricing period for liabilities & 0.2 & -0.1 & 0.2 & 0.3 & 0.0 & 0.0 & 0.5 & $\begin{array}{l}\text { data not } \\
\text { collected }\end{array}$ & 0.3 & -0.5 & 0.0 & $\begin{array}{l}\text { data not } \\
\text { collected }\end{array}$ & 0.3 & $\begin{array}{l}\text { data not } \\
\text { collected }\end{array}$ \\
\hline 49. Duration of assets & 0,5 & -0.4 & 0.3 & -0.8 & 0.0 & 0.0 & 1.0 & $\begin{array}{l}\text { data not } \\
\text { collected }\end{array}$ & 0.5 & -0.7 & 0.5 & -0.7 & 1.0 & 0.0 \\
\hline 50. Duration of liabilities & 0.4 & -0.3 & 0.3 & -0.8 & 0.0 & 0.0 & 1,0 & $\begin{array}{l}\text { data not } \\
\text { collected }\end{array}$ & 0.5 & -0.7 & 0.3 & -0.5 & 1.0 & 0.0 \\
\hline 51. Ratio of gross equity position to own funds & 0.6 & 0.2 & 0.7 & 0.0 & 0.8 & 0.3 & 0.3 & 0.5 & 0.3 & 0.3 & 0.3 & 0.3 & 0.8 & -0.2 \\
\hline 52. Ratio of net equity position to own funds & 0.5 & 0.0 & 0.3 & 0.0 & 0.6 & 0.2 & 1.0 & $\begin{array}{l}\text { data not } \\
\text { collected }\end{array}$ & 0.7 & 0.5 & 0.7 & -0.5 & 0.8 & 0.3 \\
\hline 53. Ratio of gross position in commodities to own funds & 0.4 & 0.4 & 0.2 & 0.5 & 0.0 & $\begin{array}{l}\text { data not } \\
\text { collected }\end{array}$ & 1.0 & $\begin{array}{l}\text { data not } \\
\text { collected }\end{array}$ & 0.0 & $\begin{array}{l}\text { data not } \\
\text { collected }\end{array}$ & 0.5 & 0.7 & 1.0 & $\begin{array}{l}\text { data not } \\
\text { collected }\end{array}$ \\
\hline 54. Ratio of net position in commodities to own funds & 0.4 & 0.4 & 0.4 & 0.5 & 0.0 & $\begin{array}{l}\text { data not } \\
\text { collected }\end{array}$ & 1.0 & $\begin{array}{l}\text { data not } \\
\text { collected }\end{array}$ & 0.0 & $\begin{array}{l}\text { data not } \\
\text { sollected }\end{array}$ & 0.5 & 0.7 & 1.0 & $\begin{array}{l}\text { data not } \\
\text { collectec }\end{array}$ \\
\hline
\end{tabular}

Source; IMF Survey on the Use, Compilation, and Dissemination of Macropridential Indicators.

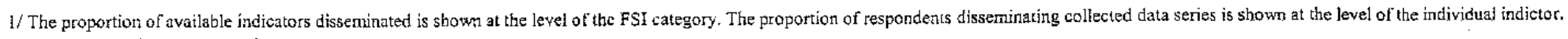
Numbers rounded to the nearest 0.1 .

2/ "Data not collecred" indicates that an eagerness tatio cannot be compiled because either none of the crisis and/or noncrisis countries collect data on the indicator. 
Table 4. Eagerness to Disseminate Core Financial Soundness Indicators (2000) $1 /$

\begin{tabular}{|c|c|c|c|c|c|c|c|}
\hline & All respondents & Advanced & Africa & Asia & $\begin{array}{l}\text { Middle } \\
\text { East }\end{array}$ & $\begin{array}{c}\text { Western } \\
\text { Hemisphere }\end{array}$ & Transition \\
\hline \multicolumn{8}{|l|}{ Capital Adequacy } \\
\hline 1. Capital Adequacy Ratio & 0.6 & 0.8 & 0.3 & 0.4 & 0.4 & 0.6 & 0.8 \\
\hline 2. Basel Tier 1 Capital to risk-weighted assets & 0.5 & 0.6 & 0.5 & 0.4 & 0.3 & 0.6 & 0.8 \\
\hline \multicolumn{8}{|l|}{ Asset Quality (Lending Institution) } \\
\hline 8. Distribution of loans, by sector & 0.8 & 0.9 & 0.8 & 0.6 & 0.9 & 0.8 & 0.8 \\
\hline 14. Ratio of total large loans to own funds & 0.3 & 0.1 & 0.4 & 0.0 & 0.4 & 0.6 & 0.5 \\
\hline 15. Ratio of gross nonperforming loans to total assets & 0.7 & 0.7 & 0.7 & 0.5 & 0.4 & 0.9 & 0.7 \\
\hline 16. Ratio of nonperforming loans net of provisions to total assets & 0.7 & 0.6 & 0.8 & 0.8 & 0.4 & 0.8 & 0.6 \\
\hline \multicolumn{8}{|l|}{ Profitability and Competitiveness } \\
\hline 26. Ratio of profits to period-average assets ( $R O A$ ) & 0.6 & 0.8 & 0.4 & 0.5 & 0.3 & 0.8 & 0.7 \\
\hline 27. Ratio of profits to period-average equity (ROE) & 0.7 & 0.9 & 0.4 & 0.5 & 0.3 & 0.8 & 0.7 \\
\hline 28. Ratio of net interest income to profits & 0.7 & 0.8 & 0.6 & 0.4 & 0.4 & 0.7 & 0.7 \\
\hline 30. Ratio of operating costs to net interest income & 0.6 & 0.8 & 0.7 & 0.4 & 0.3 & 0.6 & 0.7 \\
\hline \multicolumn{8}{|l|}{ Liquidity Indicators } \\
\hline 36. Ratio of liquid assets to total assets & 0.5 & 0.5 & 0.3 & 0.4 & 0.3 & 0.7 & 0.7 \\
\hline 37. Ratio of liquid assets to liquid liabilities & 0.5 & 0.5 & 0.3 & 0.4 & 0.3 & 0.7 & 0.7 \\
\hline \multicolumn{8}{|l|}{ Sensitivity to Market Risk } \\
\hline 46. Ratio of net foreign currency position to own funds & 0.5 & 0.4 & 0.5 & 0.3 & 0.3 & 0.4 & 0.7 \\
\hline 49. Duration of assets & 0.5 & 0.3 & 0.0 & 1.0 & 0.5 & 0.5 & 1.0 \\
\hline 50. Duration of liabilities & 0.4 & 0.3 & 0.0 & 1.0 & 0.5 & 0.3 & 1.0 \\
\hline
\end{tabular}

Source: IMF Survey on the Use, Compilation, and Dissemination of Macroprudential Indicators.

1/ The proportion of respondents disseminating collected data seties is shown. All numbers rounded to the nearest 0.1. Core indicators as defined by the IMF. 
Table 5. Eagerness to Disseminate Encouraged Financial Soundness Indicators (2000) $1 /$

Appendix III

\begin{tabular}{|c|c|c|c|c|c|c|c|}
\hline & All respondents & Advanced & Africa & Asia & Middle East & $\begin{array}{l}\text { Western } \\
\text { Hemisphere }\end{array}$ & Transition \\
\hline \multicolumn{8}{|l|}{ Deposit-taking institutions } \\
\hline 4. Leverage Ratio & 0.7 & 0.8 & 0.7 & 0.3 & 0.6 & 0.9 & 0.8 \\
\hline 6. Ratio of total gross asset position in financial derivatives to profits & 0.6 & 0.4 & 0.9 & 0.3 & 0.5 & 0.4 & 0.8 \\
\hline 7. Ratio of total gross liability position in financial dcrivatives to own funds & 0.5 & 0.4 & 0.0 & 0.3 & 0.5 & 0.4 & 0.8 \\
\hline 12. Distribution of credit extended, by country or region & 0.7 & 0.8 & 0.8 & 0.6 & 0.2 & 0.9 & 0.6 \\
\hline 29. Ratio of trading and foreign exchange gains/losses to profits & 0.6 & 0.7 & 0.6 & 0.3 & 0.4 & 0.7 & 0.6 \\
\hline 31. Ratio of staff costs to operating costs & 0.6 & 0.7 & 0.7 & 0.4 & 0.3 & 0.6 & 0.7 \\
\hline 32. Spread between reference lending and deposit rates & 0.8 & 0.9 & 0.8 & 0.5 & 0.5 & 0.9 & 0.8 \\
\hline 35. Average intcrbank bid-ask spread for 3-month local-currency deposits & 0.6 & 0.4 & 1.0 & 0.5 & 0.7 & $\begin{array}{l}\text { data not } \\
\text { collected }\end{array}$ & 0.6 \\
\hline 43. Ratio of customer deposits to tatal (noninterbank) loans & 0.8 & 0.8 & 0.8 & 0.7 & 0.7 & 0.6 & 0.9 \\
\hline 52. Ratio of net equity position to own funds & 0.5 & 0.3 & 0.6 & 1.0 & 0.7 & 0.7 & 0.8 \\
\hline \multicolumn{8}{|l|}{ Liquidity Indicators } \\
\hline 40. Average daily turnover in the T-bill (or central bank bill) market & 0.7 & 0.7 & 0.8 & 0.5 & 0.3 & 0.7 & 0.9 \\
\hline 41. Average bid-ask spread in the T-bill (or central bank bill) market & 0.5 & 0.2 & 0.7 & 0.5 & 0.5 & 0.0 & 0.7 \\
\hline \multicolumn{8}{|l|}{ Corporate Sectors } \\
\hline 17. Ratio of corporate debt to own funds ("debt-equity ratio") & 0.8 & 0.9 & 0.4 & 0.5 & 1.0 & 0.5 & 0.8 \\
\hline 18. Ratio of corporate profits to equity & 0.8 & 0.9 & 0.6 & 0.3 & 0.7 & 0.5 & 0.8 \\
\hline 19. Ratio of corporate debt service costs to total corporate income & 0.7 & 0.8 & 0.6 & 0.5 & 0.7 & 0.0 & 0.6 \\
\hline 20. Corporale net foreign curtency exposure & 0.5 & 0.3 & 0.8 & 0.3 & 1.0 & 0.0 & 0.8 \\
\hline 24. Number of applications for protection from creditors & 0.8 & 0.9 & 1,0 & 1,0 & 1.0 & 0.0 & 0.5 \\
\hline \multicolumn{8}{|l|}{ Households } \\
\hline 21. Ratio of houschold total debt to GDP & 0.6 & 0.8 & 0.3 & 0.5 & 0.8 & 0.3 & 0.3 \\
\hline \multicolumn{8}{|l|}{ Real Estate Markets } \\
\hline 9. Loans for investment in commercial real estate & 0.7 & 0.7 & 0.7 & 0.7 & 0.8 & 0.6 & 1.0 \\
\hline 10. Loans for investment in residential real estate & 0.8 & 0.9 & 0.7 & 0.7 & 0.8 & 0.8 & 1.0 \\
\hline
\end{tabular}

$1 /$ The proportion of respondents disseminating collected data series is shown. All numbers rounded to the nearcst 0.1 . Encouraged indictors as defincd by the IMF. 


\section{References}

Allum, P., and M. Agca, 2001, "Economic Data Dissemination: What Influences Country Performance On Frequency and Timeliness?," IMF Working Paper 01/173 (Washington: International Monetary Fund).

Bordo, M., 1985, "Financial Crises, Banking Crises, Stock Market Crashes, and the Money Supply: Some International Evidence (1870-1933)," in Financial Crises and the World Banking System, ed. by Forrest Capie and Geoffrey Wood (New York: St. Martin's Press).

Commission of the European Communities, International Monetary Fund, Organization for Economic Cooperation and Development, United Nations, and World Bank, 1993, System of National Accounts 1993 (Brussels: Commission of the European Communities).

Caprio, G., Jr., and D. Klingebiel,1997, "Banking Insolvency: Bad Luck, Bad Policy, or Bad Banking," paper presented at the Annual World Bank Conference on Development Economics, Washington.

Cordella, T., and E. Yeyati, 1997, "Public Disclosure and Bank Failures," IMF Working Paper 97/96 (Washington: International Monetary Fund).

Corsetti, G., P. Pesenti, and N. Roubini,1998, "What Caused the Asian Currency and Financial Crises? Part I. The Macroeconomic Overview," NBER Working Paper No. 6833 (Cambridge, Massachusetts: National Bureau of Economic Research).

Demigürç-Kunt, A., and E. Detragiache, 1998a, "The Determinants of Banking Crises in Developing and Developed Countries," Staff Papers, International Monetary Fund, Vol. 45, No. 1, pp. 81-109.

1998b, "Financial Liberalization and Financial Fragility," IMF Working Paper 98/83 (Washington: International Monetary Fund).

1999, "Monitoring Banking Sector Fragility: A Multivariate Logit Approach with an Application to the 1996/1997 Banking Crises," (unpublished; Washington: International Monetary Fund).

Eichengreen, B., and A. Rose, 1998, "Staying Afloat When the Wind Shifts: External Factors and Emerging-Market Banking Crises," NBER Working Paper No. 6370 (Cambridge, Massachusetts: National Bureau of Economic Research).

Evans, O., A. Leone, M. Gill, and P. Hilbers, 2000, Macroprudential Indicators of Financial System Soundness, IMF Occasional Paper No. 192 (Washington: International Monetary Fund). 
Frydl, E., 1999, "The Length and Cost of Banking Crises," IMF Working Paper 99/30 (Washington: International Monetary Fund).

Hardy D., and C. Pazarbasioglu, 1998, "Leading Indicators of Banking Crises: Was Asia Different?" IMF Working Paper 98/91 (Washington: International Monetary Fund).

International Monetary Fund, 2000, Monetary and Financial Statistics Manual (Washington).

, World Economic Outlook (Washington), issues of April 1998 and April 2002.

Kaminsky, G., 1998, "Currency and Banking Crises: The Early Warnings of Distress," International Finance Discussion Paper No. 629, (Washington: Board of Governors of the Federal Reserve System).

, and C. Reinhart, 1999, "The Twin Crises: The Causes of Banking And Balance of Payments Problems," American Economic Review, Vol. 89 No. 3 (June), pp. $473-500$

Lindgren, C., G. Garcia, and M. Saal, 1996, "Bank Soundness and Macroeconomic Policy" International Monetary Fund.

Rojas-Suarez, L., and S. Weisbrod, 1986, "Banking Crises in Latin America: Experiences and Issues," in Banking Crises in Latin America, ed. by Ricardo Hausmann and Liliana Rojas-Suarez (Baltimore: Johns Hopkins University Press), pp. 3-21.

Sundararajan, V., C. Enoch, A. San Jose, P. Hilbers, R. Krueger, M. Moretti, and G. Slack, 2002, Financial Soundness Indicators: Analytical Aspects and Country Practices, IMF Occasional Paper No. 212 (Washington: International Monetary Fund). 